\author{
Universidade Federal de Goiás \\ Faculdade de Informação e Comunicação \\ Programa de Pós-Graduação em Comunicação
}

\title{
A Especificidade Comunicacional do Jornalismo a Partir de uma Fenomenologia Pura:
}

Princípios a uma Metafísica do Estar-em-comunicação 


\section{TERMO DE CIÊNCIA E DE AUTORIZAÇÃO PARA DISPONIBILIZAR AS TESES E DISSERTAÇõES ELETRÔNICAS (TEDE) NA BIBLIOTECA DIGITAL DA UFG}

$\mathrm{Na}$ qualidade de titular dos direitos de autor, autorizo a Universidade Federal de Goiás (UFG) a disponibilizar, gratuitamente, por meio da Biblioteca Digital de Teses e Dissertações (BDTD/UFG), sem ressarcimento dos direitos autorais, de acordo com a Lei no 9610/98, o documento conforme permissões assinaladas abaixo, para fins de leitura, impressão e/ou download, a título de divulgação da produção científica brasileira, a partir desta data.

\section{Identificação do material bibliográfico: \\ [X] Dissertação \\ [ ] Tese}

\section{Identificação da Tese ou Dissertação}

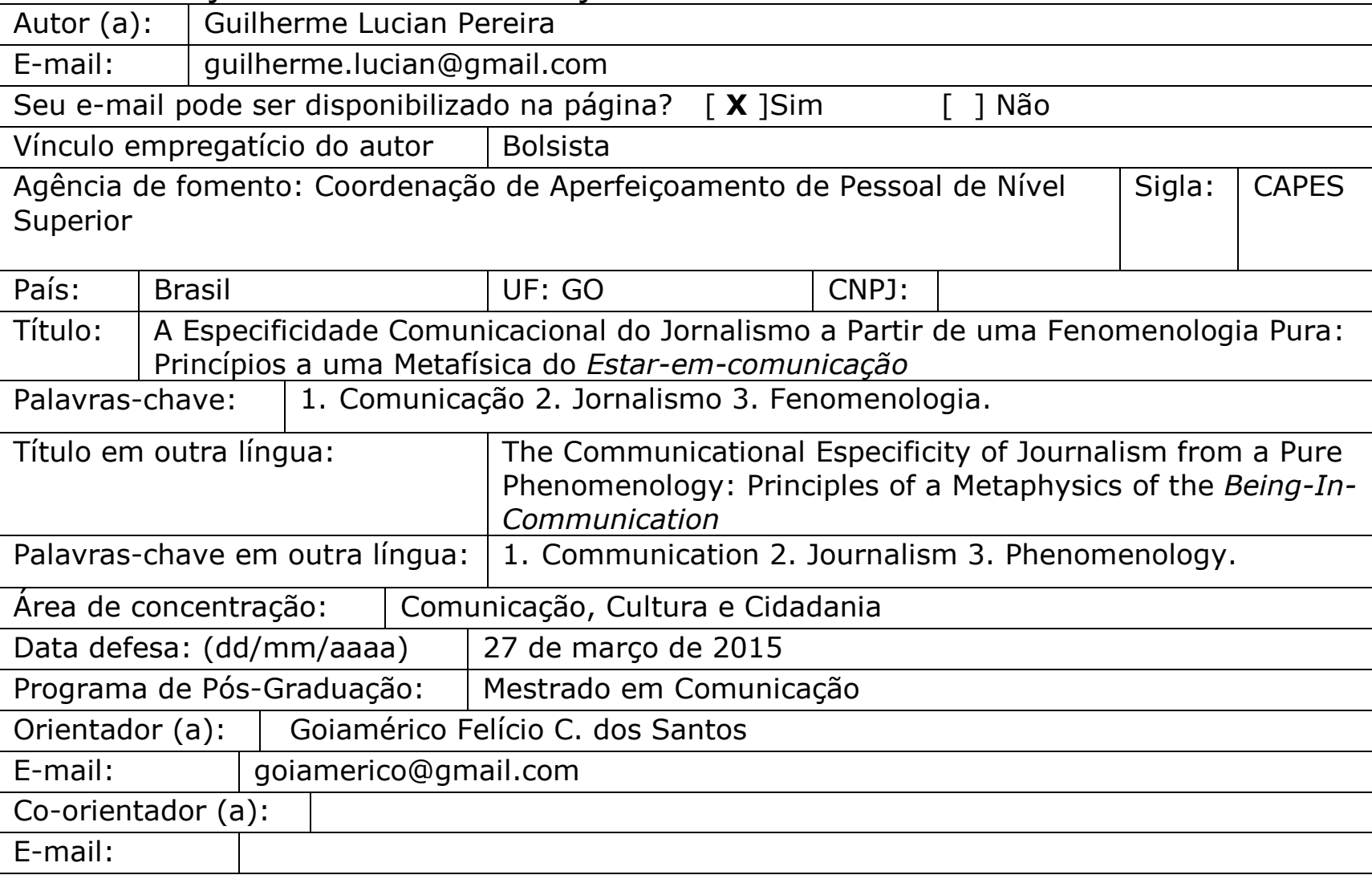

\section{Informações de acesso ao documento:}

Liberação para disponibilização? ${ }^{1}$

$[\mathbf{X}]$ total $\quad[\quad]$ parcial

Em caso de disponibilização parcial, assinale as permissões:

[ ] Capítulos. Especifique:

[ ] Outras restrições:

Havendo concordância com a disponibilização eletrônica, torna-se imprescindível o envio do(s) arquivo(s) em formato digital PDF ou DOC da tese ou dissertação.

O Sistema da Biblioteca Digital de Teses e Dissertações garante aos autores, que os arquivos contendo eletronicamente as teses e ou dissertações, antes de sua disponibilização, receberão procedimentos de segurança, criptografia (para não permitir cópia e extração de conteúdo, permitindo apenas impressão fraca) usando o padrão do Acrobat.

Assinatura do (a) autor (a)

Data: $15 / 04 / 2015$

\footnotetext{
${ }^{1}$ Em caso de restrição, esta poderá ser mantida por até um ano a partir da data de defesa. A extensão deste prazo suscita justificativa junto à coordenação do curso. Todo resumo e metadados ficarão sempre disponibilizados.
} 


\section{Guilherme Lucian Pereira}

\section{A Especificidade Comunicacional do Jornalismo a Partir de uma Fenomenologia Pura:}

Princípios a uma Metafísica do Estar-em-comunicação

Dissertação apresentada ao final do curso de Mestrado do Programa de Pós-Graduação em Comunicação como requisito à obtenção do título de Mestre em Comunicação.

Área de concentração: Comunicação, Cultura e Cidadania

Orientador(a): Goiamérico Felício Carneiro dos Santos

GOIÂNIA 
Ficha catalográfica elaborada automaticamente com os dados fornecidos pelo(a) autor(a), sob orientação do Sibi/UFG.

\author{
Lucian Pereira, Guilherme \\ A Especificidade Comunicacional do Jornalismo a Partir de uma \\ Fenomenologia Pura [manuscrito] : Princípios a uma Metafísica do \\ Estar-em-comunicação / Guilherme Lucian Pereira. - 2015. \\ CXX, $120 \mathrm{f}$.
}

Orientador: Prof. Dr. Goiamérico Felício Carneiro dos Santos. Dissertação (Mestrado) - Universidade Federal de Goiás, Faculdade de Informação e Comunicação (FIC), Programa de Pós-Graduação em Comunicação, Goiânia, 2015.

Bibliografia.

1. Comunicação. 2. Jornalismo. 3. Fenomenologia. I. Carneiro dos Santos, Goiamérico Felício, orient. II. Título. 


\section{A Especificidade Comunicacional do Jornalismo a Partir de uma Fenomenologia Pura:}

Princípios a uma Metafísica do Estar-em-comunicação

Dissertação apresentada como defesa no curso de Mestrado do Programa de Pós-Graduação em Comunicação como requisito à obtenção do título de Mestre em Comunicação, com realização em 27 de março de 2015 pela banca examinadora composta pelos seguintes professores:

Prof. Dr. Goiamérico Felício Carneiro dos Santos

Orientador - FIC/UFG

Prof. Dr. Luiz Antonio Signates Freitas

FIC/UFG

Prof. Dr. Luiz Claudio Martino

FAC/UNB

GOIÂNIA 
"Possuir é perder. Sentir sem possuir é guardar, porque é extrair de uma coisa a sua essência" -

Fernando Pessoa 


\section{RESUMO}

Intenta-se aqui investigar até que ponto é possível observar uma configuração especificamente comunicacional no modo como o jornalismo se apresenta enquanto atividade. Noutros parâmetros, em que medida o resultado desse exercício, como pretensão mesma de um narrar-sobre, pode mostrar-se como um tipo de evento essencialmente comunicativo? Para tanto, será pertinente considerar a noção de intencionalidade informativa - ela mesma enquanto primado à emergência do fazer jornalístico - para além da dimensionalidade recorrente que lhe é atribuída, i.e., enquanto mera ordenadora das coisas mesmas do mundo vivido a ponto de engendrar um todo que nos seja significativo ao entendimento. Partindo então de uma $\varepsilon \pi \circ \chi \eta$ (epoché) própria à investigação fenomenológica, os esforços teóricos se aterão à busca por uma essência ao fenômeno comunicacional até que, disto, emerja algo singular a ponto de ser considerado como parte da configuração apresentada hoje no jornalismo.

\section{Palavras-chave:}

1. Comunicação 2. Jornalismo 3. Fenomenologia. 


\begin{abstract}
This work intend to investigate until certain point is possible to observe a configuration specifically communicational in the journalism as activity. In other words, how the result of these exercise, as a pretension of a relate-about, can be, certainly, an inherently communicative event? Therefore, will be relevant to consider the concept of informative intentionality - viewed as primacy that from emerge of the journalistic activity - beyond of your usual dimensionality, i.e., as a mere "orderer" of living experienced environment, until point to formulate a singular apprehension that lead to semantic circulation. Considering then a $\varepsilon \pi \circ \chi \eta$ (epoché) as a perspective of phenomenological search, all the theoretical attempts will lead to pursuit for an essence of the communicational phenomenon until we can able to see the configuration yours on the modern journalism.
\end{abstract}

\title{
Key-words:
}

1. Communication 2. Journalism 3. Phenomenology. 
1 PROLEGÔMENOS À QUESTÃo DO EIDOS COMUNICACIONAL .................. 8

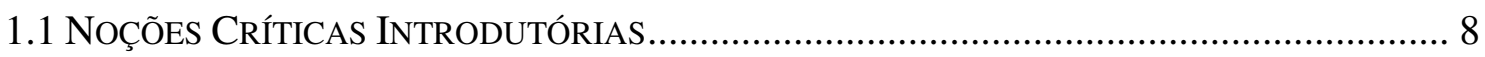

2 DA INTENCIONALIDADE COMO PRINCÍPIO AO IN-COMUNICAR (OU DA GÊNESE DE UM ESTAR-PARA-O-OUTRO PELO INTENCIONAR)................... 14

2.1 Do QUERER ORIGINÁrio (OU Do Diálogo COMO ATO ESSENTE Ao COMUNICAR) .. 26 2.1.1 Do Encontrar-se enquanto Preenchimento do Intencionar (ou do Dis-positivo como Atendimento ao Querer Fundante) .................................................................... 36

3 DAS FORMAÇÕES SOCIAIS PELO IN-COMUNICAR (OU DA UNIDADE COMO PRINCÍPIO DO ESTAR-EM-SOCIALIDADE) ....................................... 47

3.1 Da FormaÇão dos Espaços Públicos ao Início da Atividade JoRnalística .. 52 3.1.1 Da Técnica como Princípio Configurativo do Fazer Jornalístico (ou da não Subexistência do Jornalismo Enquanto Razão Prática à Vida) ....................................... 60

4 DA ANTINOMIA ENTRE COMUNICAÇÃO E JORNALISMO ………………... 73

4.1 INFORMAR ENQUANTO UM PRETENDER-SE-COMUNICATIVO ........................................ 73

4.1.1 Do Especificamente Comunicacional no Fazer Jornalístico .................................... 83

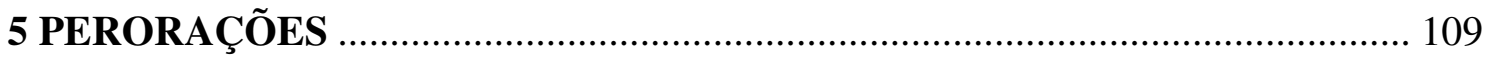

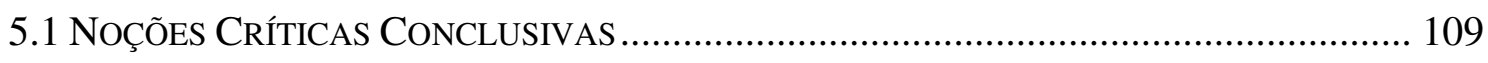

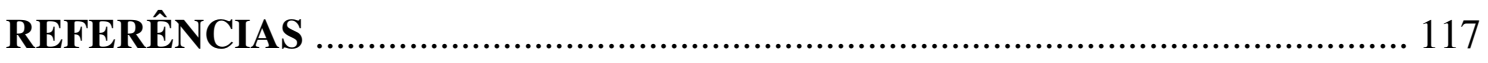

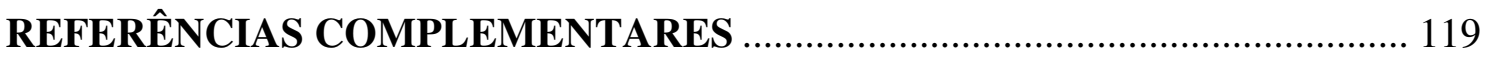




\section{PROLEGÔMENOS À QUESTÃO DO EIDOS COMUNICACIONAL}

\subsection{Noções Críticas Introdutórias}

Discursar a respeito da atividade jornalística é também um modo particular de tentar compreender uma dimensionalidade sua que nada tenha que ver com a perspectiva recorrente a ela atribuída, i.e., tão somente enquanto exercício que se atém ao veicular de informações. Se se assume aqui tal postura, é sinal de que há algo a mostrar-se oculto no tipo de configuração com que se apresenta até o ponto de não permitir com que enxerguemos o eidos (દĩ்o $)$ da lógica operativa manifesta no saber-fazer característico da profissão. Sendo assim, os esforços teóricos deste trabalho se aterão a debruçar-se nessa essência pretendida, tomando-a como uma singularidade própria ao fenômeno comunicacional, muito embora não no sentido de considerá-la uma subexistência deste, mas enquanto uma das constituições existenciárias do comunicar.

Noutros termos, portanto, seguiremos aqui dois direcionamentos iniciais que, ao fim, conduzirão ao mesmo ponto: observar a especificidade comunicacional do jornalismo na condição de atividade social cujo princípio configurativo muito tenha que ver com a essência mesma do que é o comunicar. O primeiro desses direcionamentos concerne ao modo como o próprio fenômeno comunicacional é visto naquilo que lhe é de mais essente, i.e., na forma com que se deixa mostrar por e em si mesmo até o ponto de emergir nisto algo com o qual passemos a considerar como eidos instituínte do que lhe é originário. Disto, passaremos ao segundo, que diz respeito aos modos singulares pelos quais o jornalismo - enquanto atividade mesma - se configurou na medida em que alteravam-se as urgências que faziam operar a legitimidade sua de ser e estar à dinâmica da espacialidade do vivido. Somente então, analisados ambos à perspectiva fenomenológica quanto a suspensões de juízo a partir de reduções eidéticas, trataremos daquilo que é possível tomar por comunicação na lógica jornalística de se fazer operar não como agente mediador, mas enquanto condição de possibilidade a circunstâncias situacionais que potencializam atos essencialmente comunicativos.

Reduzir eideticamente o fenômeno comunicacional a ponto de enxergar uma essência sua fundante, exige, antes, observá-lo tal qual a primeira vez que a ele nos atemos, no sentido 
de formar uma abertura pontual de parênteses que permitirá a eliminação dos atributos que não lhe são essenciais. Noutros termos, partir de tudo o que comunicar não é, para, somente então, chegarmos ao essente que lhe seja fundante. Esse atributo singular e ontologicamente constituinte é o que se apresentará como possibilidade à inferência acerca desse mesmo tipo de configuração operando à lógica de uma episteme jornalística.

Não se trata, evidentemente, de propor um tipo de constituição ontológica ao exercício jornalístico, mas tão somente de observar nas singularidades de suas articulações epistemológicas, uma configuração especificamente comunicacional no sentido de se apresentar não enquanto fim último do jornalismo, mas como primado do próprio saber-fazer que institui a atividade. Do mesmo modo como, essa abertura de parênteses na condição de um suspender de juízo, é menos o desconsiderar do que já foi analisado a respeito do eidos comunicacional e da episteme jornalística, do que, propriamente, de chegarmos a uma noção outra de ambos. Esta, que de sua vez pode se mostrar pertinente a ponto de estreitar os laços existenciais entre comunicação e jornalismo e não de apartá-los como se compusessem fenomenologicamente tipos antinômicos de configuração ou essência mesmas.

A observação de um tipo específico de configuração comunicacional na atividade jornalística terá sentido apenas se, operando à luz da fenomenologia, servir enquanto princípio de um racionalizar-sobre, i.e., de tentar enxergar, no modo como o jornalismo se nos apresenta enquanto agir-no-mundo, o verdadeiro emergente que se mostre não pela arbitrariedade de pertinência entre um e outro, mas por uma essência que se constitui comum a ambos. Nesse sentido, as reduções eidéticas que se fazem aqui necessárias devem nos conduzir ao essente do fenômeno comunicacional e, disto, observar essa mesma singularidade à manifestação da episteme jornalística. Percebam que, no entanto, o próprio agir do e no jornalismo terá de ser considerado a partir dos critérios fenomenológicos concernentes à busca de um eidos que lhe seja fundante. Como, então, tratar de uma essência à ação sem que esta se apresente tão somente enquanto um tipo de ontologia jornalística? Em termos gerais, a proposta ontológica deste trabalho caminha no sentido de enxergar o obscuro do fenômeno comunicacional a ponto de extrairmos disto algo com o qual se possa tomar por essencial. Mas a observação analítica desse verdadeiro emergente, quando aclimatado à lógica processual do jornalismo, nos exige uma compreensão de segunda ordem: saber em que medida a instituição epistemológica do próprio saber-fazer jornalístico se mostra como tal por ser, antes, parte do que nos funda ontologicamente seres de-e-para-o-comunicar. 
Não se trata, por outro lado, de forçar uma epistemologia tipicamente ontológica que se mostre útil a ponto de compreender a dinâmica do jornalismo, mas de observar nesta as singularidades existenciárias do fenômeno comunicacional no modo como se apresentam nos recônditos do agir jornalístico. Dito noutros parâmetros, tentar fundar primeiro as bases constituintes da comunicação - pelas possibilidades ontológicas da fenomenologia - e, num segundo momento, compreender a forma como a atividade jornalística se alçou enquanto urgência mesma ao social, instituindo a episteme que ainda se lhe apresenta como essência. Somente então, analisados esses aspectos, será possível enxergar o essente da comunicação a operar na espacialidade epistemológica do exercício jornalístico, até o ponto de inferirmos a respeito do que há de especificamente comunicacional na lógica do agir que lhe configura.

Deste modo, o escopo de todas as problematizações neste trabalho direcionam ao sentido principal citado pouco antes, i.e., de tentar compreender até que ponto o eidos do fenômeno comunicacional se apresenta à dinâmica epistemológica do jornalismo, enxergando este primeiro não como existencial secundário do agir visto no segundo, mas enquanto essência mesma da qual parte a própria intencionalidade de narrar-a-respeito-de, característica do jornalismo. Por isso a parte inicial deste trabalho se limita à instituição dos fundamentos ontológicos da comunicação, na medida em que seus atributos tornam-se mais aclarados no sentido de permitir com que avistemos, pelo des-velar, algo com o qual podemos então tomar por essencial ao comunicar.

Em princípio, a proposta primeira aqui apresentada nos direciona ao entendimento da comunicação enquanto fenômeno que nos institui seres com-e-para-o-outro, em que constituímos nosso existir no-mundo a partir de um pôr-se-a-comunicar. Isso não significa, evidentemente, que a compreensão epistemológica da atividade jornalística se apresente apenas como temática secundária em relação à investigação do mais essente do fenômeno comunicacional. É, pelo contrário e enquanto exercício mesmo, parte daquilo que compreenderemos como sendo de mais singular nessa perspectiva existencial quanto a um estar-em-comunicação e, disto, estar-para-o-outro no horizonte do comunicar. Assumimos aqui (de antemão) a postura fenomenológica de que o saber-fazer jornalístico muito tem que ver com essa dimensionalidade humanística de compreender a comunicação, sendo isto menos o resultado do que emerge de uma dinâmica processual de transmissão informativa do que, propriamente, do modo como o jornalismo se dis-põe à compreensibilidade sustentada pelo sentido de seu existir enquanto tal. 
Desta problematização principal, seguiremos a outras que estão em consonância com a postura metodológica de redução eidética, i.e., de uma epoché ( $\varepsilon \pi \mathrm{o} \chi \eta)$ na condição de ponto de partida para se buscar a essência do fenômeno comunicacional. Estas, por sua vez, se apresentarão como resultado de tudo o mais que emergir na procura pelo eidos, auxiliando na compreensão dela própria enquanto tal. E na tentativa de instituir fundamentos outros à comunicação a ponto de observar suas fronteiras ontológicas quando aclimatados à episteme jornalística, também intenta-se aqui promover diálogos pertinentes no sentido de enxergar comunicação e jornalismo como partes de uma totalidade de sentido.

Diante disso, percebam que aqui o escopo direciona-se à contramão das posições hoje recorrentes e que concernem à tentativa de dissociação entre ambos, como se, na emergência do exercício jornalístico, não houvesse nada a ponto de tomarmos por comunicação. Essa atitude mostra-se como aparentemente sensata, sobretudo se a enxergamos como um modo particular de se reforçar epistemologicamente o exercício. Mas, por outro lado, ele próprio se vê então limitado a servir de instrumentum a tudo mais que o for, como se, enquanto saberfazer, resignasse-se tão só a um órganon cujos princípios são estratégicos.

Se, de um lado, considera-se aqui a impossibilidade de uma não-dissociação entre comunicação e jornalismo, por outro, sua episteme em nada se fragiliza quando analisamos uma especificidade comunicacional que lhe é concernente. A tentativa de se enxergar a configuração de um eidos ao fenômeno da comunicação operando na espacialidade institucionalizada do jornalismo é menos questão de se forçar um construto ontológico do que, com efeito, tentar compreender a manifestação mesma desse عĩ $\delta o \varsigma$ na lógica operativa de ser e estar própria à atividade jornalística. Com isso, portanto, talvez seja possível lançar luz sobre um entendimento outro acerca da própria constituição do jornalismo para além dos limites seus epistemológicos, i.e., tendo ao cerne de sua atividade um princípio orientador ao comunicar enquanto instituição nossa no-mundo. Isso não seria, de saída, um pressuposto a servir como idealização de um estado mesmo de coisas ao jornalismo? Não necessariamente. Observar a especificidade de uma configuração comunicacional operando na atividade jornalística nada tem que ver com a obliteração da episteme (enquanto verdadeiro emergente) que lhe é fundante. E compreendendo-a na condição de possibilidade (ou potência) do ato mesmo de um estar-para-o-outro, uma dissociação categórica entre ambos apenas nos guiaria ao mais ferramental e estratégico na emergência de um exercício como o do jornalismo. 
Nesse sentido, a medula teórica deste trabalho se constitui a partir de três sustentáculos principais, sendo o primeiro concernente aos fundamentos ontológicos do fenômeno comunicacional. A proposta, de início, é lançar luz às singularidades existenciárias do ato mesmo de comunicar, até o ponto de - por vias fenomenológicas - se fazer emergir algo a que se possa tomar por essente. A epoché aqui pretendida, enquanto postura diante do fenômeno, conduzirá ao eidos comunicativo no sentido de reduzir fenomenicamente a noção mesma de comunicação partindo do que consideramos como sendo atributos não-essenciais seus até o ponto de des-velar o verdadeiro que se apresenta por si próprio, tal como se mostra, partindo de si mesmo ${ }^{1}$.

Para tanto, como tratamos aqui de um des-velar aquilo que se apresenta por si próprio, há de se debruçar sobre o mais singular da noção mesma de intencionalidade, que é cara à fenomenologia. Neste trabalho, centraremos nossa análise em dois tipos específicos de intencionar enquanto ato de consciência, i.e., um concernente ao dar-se dos objetos que nos vem de encontro e outro que trata do modo como nos movemos a uma ação frente a este objeto. Com esse direcionamento, a proposta nessa primeira parte é tentar compreender o fenômeno comunicacional enquanto emergência mesma do próprio intencionar na condição de princípio configurativo de um comunicar prático ${ }^{2}$. Noutros termos, perceber na presentificação do Outro que se nos vem de encontro, aquilo que nos desperta ao querer mesmo do comunicar. E vontade, nestes termos, é a totalidade da própria consciência e do intencionar-o-mundo que esta nos permite.

Percebam que, até este ponto, para tratarmos a respeito de um eidos à comunicação, será preciso antes analisar as possibilidades eidéticas quanto a uma fenomenologia do querer, para somente então emergirmos com uma noção outra do próprio comunicar. Se assumimos aqui a postura de que este último, na condição de ato mesmo, é um mover-se (dis-por) que nos funda como um estar-para-o-outro ${ }^{3}$, a escolha por essa dimensão fenomenológica não é meramente arbitrária. Pelo contrário, se mostra necessária caso queiramos compreender os liames entre intencionalidade e comunicação. E disto, evidentemente, o modo como o

\footnotetext{
${ }^{1}$ Cf. HEIDEGGER, Martin. Ser e tempo. - Trad. Fausto Catilho - Campinas, SP: Editora da Unicamp; Petrópolis, RJ: Vozes 2012.

${ }^{2}$ Entendido aqui não como instrumental ou meramente processual, mas enquanto aquilo que se apresenta, de antemão, como sendo praticável, i.e., que se define pelo "eu posso" de um querer mesmo.

${ }^{3}$ Notem que, a partir do exposto até o momento, essa noção é menos um mero procedimento de ação do que, propriamente, uma constituição ontológica (e, portanto, existenciária) daquilo que nos institui no-mundo a partir de nossa disposição responsável ao outro. Essa noção segunda, concernente à responsabilidade, será melhor apresentada no próximo capítulo.
} 
exercício jornalístico se apresenta enquanto intencionalidade no-mundo a partir daquilo que lhe é especificamente comunicacional.

Se trataremos acerca da ação de comunicar como uma emergência daquilo que intencionamos pela consciência, será também pertinente observar o que exatamente intencionamos quando da percepção de um ver-se-no-mundo. Evidentemente, damo-nos conta da presença de um Outro a nós semelhante e que se nos apresenta enquanto tal por também partilhar conosco desse mesmo perceber. Nesse sentido, qual a pertinência entre o intencionar da figura do Outro com o querer singular que nos põe ao encontro dessa espécie de fronteira ${ }^{4}$ que nos aparta? E que tem isso que ver com o jornalismo enquanto atividade mesma? Esses direcionamentos são extensões analíticas pontuais da problematização maior deste trabalho, e, portanto, são fundamentais à compreensão (do enxergar) daquilo que há de comunicacional no saber-fazer jornalístico.

Sendo assim, resta pontuar cada um dos construtos teóricos que esposaremos no correr deste trabalho a ponto de estruturarmos as bases ontológicas do fenômeno comunicacional. Disto, seguir com o segundo sustentáculo de nossa medula conceitual, concernente às formações singulares que engendraram as articulações de uma episteme jornalística, para, somente então, observarmos o que emergirá a ponto de tomarmos como especificamente comunicacional.

\footnotetext{
${ }^{4}$ Aqui, no sentido atribuído, a noção de fronteira pressupõe porosidade(s) como princípio à fusão de horizontes entre os sujeitos e não, necessariamente, de limites impostos pelo próprio encontrar-se.
} 


\section{DA INTENCIONALIDADE COMO PRINCÍPIO AO IN-COMUNICAR (OU DA GÊNESE DE UM ESTAR-PARA-O-OUTRO PELO INTENCIONAR)}

Prosseguindo com os preâmbulos conceituais expostos até aqui, podemos agora tratar a respeito de um modo singular pelo qual intencionamos algo no-mundo. Este, enquanto ato da consciência, nos faz dirigir toda nossa capacidade perceptiva àquilo que se nos apresenta por vir-de-encontro - como objeto. Nesse sentido, trata-se sobretudo de uma direcionalidade ${ }^{5}$, i.e., uma maneira própria cujo fim último se dá pelo agir que nos põe diante do que se vê já à mão como forma de preenchimento de aspiração. Mas percebam que, para que esse encontrar-se se efetive como tal, o próprio sentir da vontade não é suficiente, pois mostrar-seia sempre na condição de potência. Que há, afinal, de tão particular nesse querer que se mostra como devir a ponto de inferirmos sobre a possibilidade de haver nisto um essente à comunicação?

Em primeiro lugar, é preciso instituirmos as bases de uma fenomenologia da vontade, caso queiramos compreender as especificidades do princípio que configura o ato mesmo do comunicar. Noutros termos, há de se fazer uma suspensão de juízo quanto àquilo que se mostra como desejo e o que é já próximo aos termos como a noção de querer será aqui tratada. Reflitemos: desejar algo não é condição de possibilidade à concretização sua enquanto tal. Tampouco uma precedência no sentido de nos pôr noeticamente ao intencionado. Sob essa ótica, podemos ter por desejo realizar um passeio à órbita de Saturno sem que haja nisto uma dimensionalidade prática pressuposta. Enquanto não houver uma justificativa que se apresente enquanto dignação dos atos mesmos ${ }^{6}$, o desejar em si não será mais que um esforçar-se ao nada. Indicamos, nesses parâmetros, a necessidade de poder a operar como essência do próprio querer, i.e., as singularidades do "eu posso" como princípio configurativo de uma vontade mesma.

Notemos então que, na essência mais fundante desse poder-operar se apresenta a possibilidade de uma perspectiva de pensamento que se dirige ao não-visto. $O$ fato de não presenciarmos algo que se nos mostra enquanto tal a partir de uma visão prévia, não significa a condição mesma de não-existência. No entanto, o existir que o intencionar aqui implica se

\footnotetext{
${ }^{5}$ Cf. SEARLE, John. R. Intencionalidade. - 2. ed. - São Paulo: Martins Fontes, 2002, p. 4

${ }^{6}$ Cf. LEVINÁS, Emmanuel. Entre nós: ensaios sobre a alteridade. Petrópolis, RJ: Vozes, 1997, p. 188.
} 
dá nos termos de uma dimensionalidade daquilo que é praticável, ainda que isto se mostre tão somente enquanto projeto futuro. Por exemplo, podemos querer participar de um evento que se realizará daqui a algumas semanas. Nesse sentido, a orientação intencional de nosso querer se fundamenta tão só a partir de um projetar-se-àquilo-que-virá. E o que orienta o próprio projeto, portanto, é a motivação que nos dis-põ $e^{7}$ à postura mesma de intencionar algo.

Diante do que já foi posto, há uma inquietação que permanece: até que ponto então a orientação do próprio intencionar se volta à singularidade do que nos põe ao comunicar? Para responder a essa questão, é preciso antes compreender aspectos outros desse projetar-se enquanto intencionalidade orientada. Somos habilitados, na condição mesma de viventes nomundo, dessa capacidade particular de nos dirigirmos a objetos ou estados de coisas a partir de ações conscientes ${ }^{8}$ e, disto, formarmos conscientemente as condições de voluntariedade enquanto modus do dirigir-se-a e do dominar- $a$. Sob essa perspectiva, o que tomamos aqui por consciência não pode ser outra coisa senão o estar pressuposto na implicabilidade do sujeito, i.e., a mundidade da própria posição-diante-de-si ${ }^{9}$. Isso pode ser melhor explicado quando entendemos esse pôr-se diante de algo intencionado como um modo de orientação nossa em relação às coisas mesmas que fazem parte de nosso mundo circundante. Noutros termos, apreendemos e compreendemos pelo intencionar de tudo o mais que nos circunda, de modo que o não-visto das coisas se nos apresente ainda que nosso direcionamento a elas seja incerto.

Mas a singularidade do querer, no entanto, é menos um projetar-se ao desconhecido do que, propriamente, um despertar que nos orienta a este. Em que medida, então, esse despertar é princípio operativo do que há de mais essencial numa vontade? Ou, posto doutro modo, até que ponto é possível inferir a respeito de um início de vontade mesma no sentido de nos orientar ao des-cobrimento do que já está no mundo circundante e que nos vem de encontro?

Reflitemos: pelo intencionar das coisas e dos objetos, fazemos emergir a manifestação (essência) do ser que está oculto em tudo aquilo que se nos mostra numa dimensionalidade ôntica. Diante disso, esse aparecer $^{10}$, característico da própria intencionalidade, opera já como

\footnotetext{
${ }^{7}$ Essa noção de dis-posição - que muito tem que ver com a de dispositivo - será analisada mais adiante.

${ }^{8}$ Cf. SEARLE, 2002, p. 01.

${ }^{9}$ Cf. LÉVINAS, 1997, p. 170

${ }^{10}$ Cf. Id., ibid., p. 99.
} 
o despertar-para de que tratamos afinal. Mas isso ainda não explica o modo como essa dinâmica do intencionar nos direciona à vontade especificamente comunicacional. Em primeiro lugar, há uma insipiência quanto ao próprio querer no sentido de não bastar em si mesmo a ponto de nos mover a algo intencionado. Ou, noutros termos, a vontade não é condição de possibilidade ao atendimento dela mesma enquanto tal. Observemos, por exemplo, o rumo que a intencionalidade toma quando consideramos uma espécie de continuidade sua a servir de complemento:

\begin{abstract}
diremos que um enunciado é satisfeito se, e somente se, for verdadeiro, que uma ordem é satisfeita se, e somente se, for obedecida, que uma promessa é satisfeita se, e somente se, for cumprida, e assim por diante. Ora, essa noção de satisfação também se aplica claramente aos estados Intencionais. Minha crença será satisfeita se, e somente se, as coisas forem tais como acredito que sejam, meus desejos serão satisfeitos se, e somente se, forem realizados, minhas intenções serão satisfeitas se, e somente se, forem levadas a cabo. (SEARLE, 2002, p. 14).
\end{abstract}

Essa noção de satisfação e aqui considerada enquanto preenchimento, pode também ser entendida na condição de uma ação movente. Mas percebam que, para que o agir emerja do querer, é preciso a crença de que haja nisto a possibilidade do prático em seu sentido mais essencial, i.e., como aquilo que, no projetar-se, se apresenta já enquanto o possível pelo despertar intencional. Talvez esse pressuposto fique um tanto mais claro se o tomarmos do seguinte modo: se temos já a convicção de que nos é possível a satisfação daquilo intencionado a partir de sua dimensionalidade prática, a própria vontade deixa a dimensão do mero desejo e torna-se projeto. Até aqui, o preencher enquanto praticável do intencionado pode ser tomado como princípio operativo do que entendemos por comunicar. Mas notem que a essência dessa orientação a que tomamos por preenchimento permanece velada em si mesma, no sentido de se mostrar apenas como possibilidade de realização e não, necessariamente, enquanto aquilo que lhe é própria partindo de si mesma.

Atentemos então ao seguinte: há dois princípios básicos no sentido de fazer emergir a própria crença. Um que diz respeito ao conteúdo e outro concernente à condição para que este primeiro seja então "satisfeito" ${ }^{11}$. Disto, observemos que é possível acreditar que algo acontece somente se o conteúdo desse acontecer se apresentar tal qual a crença que a ele despendemos. E, portanto, se seu preenchimento se der nos termos do acontecimento. Por exemplo, se temos a crença de que cai granizo do céu, evidentemente o conteúdo do próprio

\footnotetext{
${ }^{11}$ Cf. SEARLE, 2002, p. 17.
} 
acreditar volta-se àquilo que acontece no instante em que o observamos, i.e., é preciso que o gelo de fato precipite-se do céu. O preencher nisto se evidencia quando temos a certeza de que aquilo que está diante de nós trata-se de um fenômeno natural previamente entendido como tal e não a ação de alguém atirando pedras de gelo como forma de falsear esse evento.

Nesse sentido, nossa crença a respeito de algo intencionado não se dá somente nos termos do absolutamente prático, mas da certeza prévia possível apenas quando da constatação. Embora constatar, sob essa perspectiva, seja também o possível manifesto. Aclimatemos então esses pressupostos ao escopo deste trabalho e ponderemos sobre o acreditar da possibilidade do comunicar. Até que ponto o fenômeno comunicacional, enquanto resultado de um des-velar prévio, se mostra também como tendo em si um conteúdo e preenchimento intencionais? Percebam que "desvelar" já evidencia os termos da própria intencionalidade, no sentido de enxergar aquilo que se mostra como tal e que está além do alcance de nossa visão. Comunicação seria assim a visão daquilo que não está presente ao ver das coisas? Evidentemente que não. Se intencionamos algo no-mundo, é sinal de que somos já capazes de ver aquilo que se nos manifesta como algo a ponto de ser intencionado. Mas percebam que, para que a intencionalidade se oriente à ação que esta pressupõe, não basta des-encobrir o não-aparente, mas, pelo contrário, desvelar o que agora se vê.

A pergunta que fica é: o que vemos então a ponto de fazer emergir de nosso intencionar o tipo singular de orientação que nos move-a-algo? Ou, grosseiramente, que é isto a que podemos agora enxergar e que ainda assim não nos é pleno enquanto totalidade de sentido? Essa coisa que resta, ou que se mostra ao intencionar, não pode ser algo senão a figura de um Outro que se nos exibe perigosamente ao intencionar. No entanto, em seu sentido mais ontológico, essa presença não nos é ainda meramente o que permanece fora, mas o pasmo inicial emergente da própria constatação. Nesse sentido, Outro é o que, dentro, se apresenta como a diferença que agride e que assusta, como o mirar de si à superfície de um espelho pela primeira vez e reconhecer ali uma proximidade em potência. Esse estar-dentro, evidentemente, é uma constituição existenciária do mundo circundante, pois o Outro, como tudo o mais que se nos apresenta pelo intencionar, simplesmente nos chega-ao-encontro. $\mathrm{O}$ que deve permancer claro é que, estar à volta de um mundo possível, não é necessariamente ocupar-se de um espaço dado. Mundo, numa perspectiva heideggeriana ${ }^{12}$, por exemplo, é “um

${ }^{12}$ Cf. HEIDEGGER, Martin. Ser e tempo. - 10. ed. - Petrópolis, RJ: Vozes, 2001. 
caráter" ${ }^{13}$ do ser-aí. Se entendemos mundo nesses parâmetros, tratamos aqui de uma fusão de horizontes em que ambos os mundos, pelo encontrar-se (que é um preencher), instituem a própria existência como tal.

Temos agora um novo direcionamento: da crença no mostrar-se prático, intencionamos o Outro a ponto de, dessa intencionalidade mesma, emergir o encontro de mundos distintos e ontologicamente separados. O Outro nos vem de encontro a partir do preencher daquilo que intencionamos de antemão. Observem então que esse preenchimento doravante tomado simplesmente por encontrar-se - se mostra como o des-velar singular do ser. Em seu aspecto mais ontológico, não se trata de perceber como exteriorização aquilo que se nos extrapola enquanto viventes, mas um ir-de-encontro diante do que já está aí. Noutros parâmetros, trata-se de um deixar-se conduzir ao que nos vem a princípio como horizonte intencionado.

Disto, portanto, chegamos à noção que nos será cara deste ponto em diante: do encontrar-se como modo existenciário da vontade que nos põe ao comunicar. Para que cada um desses pressupostos seja analisado em seus pormenores, é preciso antes compreender as singularidades de um deixar-e-fazer-ver, de modo que o próprio encontrar-se enquanto preenchimento da intencionalidade torne-se "compreensível antecipadamente como aquilo que ele é e já se dá sempre em todos os entes." ${ }^{14}$. Mas percebam que, do ponto de vista ontológico, há aqui uma diferença em relação ao modo como Heidegger enxergava o próprio sentido do fenomenológico. Des-velamento, nos termos do que aqui se propõe, é enxergar a essência do próprio ser quando este se vê de encontro com outro ser. Ou, para sermos mais exatos, quando instituímos nosso existir a partir do encontrar-se frente ao Outro intencionado na condição de alheio. Mas isso não é um mero pretexto para se aclimatar a discussão do especificamente comunicacional no mais essente do ser? Não exatamente. E por uma razão simples até: ser, em nosso entendimento, é também o emergir que se dá no acontecer do próprio encontrar-se da intencionalidade. Porque, sendo, somos orientados pela quididade do comunicar.

Temos de estabelecer, portanto, os pontos mais importantes desses pressupostos, caso queiramos compreender dimensões outras do fenômeno comunicacional. Em primeiro lugar, o encontrar-se do intencionar é já a constituição existenciária do que entendemos por sendo.

\footnotetext{
${ }^{13}$ Cf. Id., ibid., p. 105.

${ }^{14}$ Cf. Id., ibid., p. 80.
} 
Segundo, porque o que emerge do intencionar-o-outro não é algo senão o princípio operativo da vontade comunicativa. Essa instituição do que é partindo de um eu posso enquanto querer operante, é o que podemos chamar de "aventura do ser" 15 . Aventurar-se, nesses termos, é o próprio dis-por movente ao Outro, como forma de se lhe estar-para. Observemos agora, a partir do que até então foi proposto, que o ser-aí

\footnotetext{
se compreende em ser, isto é, sendo. É próprio deste ente que seu ser se lhe abra e manifeste com e por meio de seu próprio ser, isto é, sendo. A compreensão do ser é em si mesma uma determinação do ser do [ser-aí]. O privilégio ôntico que distingue [o ser-aí] está em ser el[e] ontológic[o].” (HEIDEGGER, 2001, p. 38 - Grifo nosso).
}

No entendimento ontológico daquilo a que Heidegger chama por Dasein (ser-aí), está o pressuposto de que, sendo, a emergência do que em nós há de mais essente se dá nos termos de uma condição de um privilégio quanto à sua dimensionalidade mais ôntica. Mas, no modo como aqui tentamos compreender o fenômeno comunicacional, a permanência nos aspectos constituintes desse ente privilegiado nos são insuficientes. Isso porque, com efeito, beiraríamos sempre a camada solipsista de um ser que não se vê em momento algum a operar o princípio de estar-para-o-outro. A partir de que parâmetros então podemos enxergar o existencial aí como parte instituinte do comunicar? Ou, para sermos mais claros, em que medida essa condição de possibilidade pode ser tomada como ser-junto-a àquele que também tem em si o privilégio? A compreensão dessa condição mesma se dá na dimensionalidade do relacionar-se com o ente. Mas o que teríamos se, do contrário, a circunstância relacional se apresentasse enquanto reciprocidade de seres em extensão?

Se tratamos aqui de um tipo singular de reciprocidade do relacionar, por certo temos de estabelecer os critérios ontológicos que fazem operar isso a que tomaremos deste ponto em diante como sendo relação. De início, observemos que o aspecto mais solipsista concernente ao ser é deixado de lado quando do sair-de-si em direção ao Outro, embora o princípio do relacional opere tão somente nos termos do encontrar-se. Esse pressuposto será analisado no tópico seguinte. Por hora, atentemos à constituição existenciária do ser-em, cara à ontologia fenomenológica heideggeriana. Esta, que nada tem que ver com um pôr-se-dentro simplesmente, é compreendida nos termos de uma reciprocidade relacional do ser de entes extensos. Essa extensão implica a partilha espacio-temporal, em que ambos veem-se

\footnotetext{
${ }^{15}$ Cf. LÉVINAS, 1997, p. 18.
} 
“igualmente 'dentro' do espaço 'em' um lugar”"16, sendo o sentido aquilo que emerge desse relacionar.

Percebam que, até aqui, ser-em é tratado como um modo singular no qual instituímos nosso existir no-mundo, embora nos falte algo a ponto de compreendermos como então se dá o próprio partilhar. Nos referimos acima a respeito da emergência do sentido frente ao relacionar, mas em que medida o existencial em pode ser observado nos termos de um Mitsein (ser-com), sendo este menos o estar-com do ser em relação ao ente do que, propriamente, do ser para-com-outro-ser que lhe é exterior?

Essa constituição ontológica tratada por Heidegger como sendo um estar no-mundo, se entendida tão só nos termos de um relacionar do ente com o mais essencial de seu ser, nos conduziria à noção solipsista de que cada qual compreende e se faz ver pela compreensibilidade apenas enquanto vivente individual. O que propomos aqui é observar esse princípio de reciprocidade e aplicá-lo fenomenologicamente ao relacionar que funda a constituição existenciária de um estar-para-o-outro, sem pretensão alguma de fazer disso um fundamento estável no que diz respeito ao próprio entendimento do ser. Pois este último, nos parâmetros como o enxergamos, é tido na emergência mesma do relacionar com-e-para. $\mathrm{O}$ Dasein, portanto, é aqui compreendido à luz do partilhar de sentidos entre seres extencionais até o ponto de fundar as condições de possibilidade de um con-viver pacífico e solidário. Este telos como princípio orientador à comunicação ${ }^{17}$ nada tem que ver com um estado ideal de coisas, mas, no encontrar-se do intencionado, se apresentar enquanto pacificidade àqueles que se emprestam ao comunicar.

Temos agora uma emergência outra ao princípio do comunicar: sua finalidade se apresenta enquanto orientação ao bem comum. Mas que é isto, aliás, a ponto de se fazer tão essencial ao fenômeno da comunicação? Seria o bem a idealização da emergência mesma de todo partilhar? O que aqui entendemos como sendo o bem é menos um estado ideal do mais absolutamente prático do que, propriamente, o dis-por que opera o relacionar. Nesse sentido, tratamos de Agathon (Bem), como a precedência que configura a partir de si mesma a instituição nossa no-mundo. Percebam então que, penetrando fundo a teleologia do comunicar, é possível enxergar o bem na condição de primado e não necessariamente de fim

\footnotetext{
${ }^{16}$ Cf. HEIDEGGER, 2001, p. 91.

${ }^{17}$ Que, em seu aspecto mais metafísico, se dá nos termos de um fim-último à condição humana na busca de uma orientação absoluta.
} 
último. Mas até que ponto é possível abandonar as dimensionalidades de uma escatologia à comunicação e beirar a essência de um preceder que nos serve de instituição existencial? Ou, noutros termos, como considerar o fenômeno comunicacional como algo que nos move ao estar-para-outrem? Basta, para isso, percebermos seu telos como aquilo que se apresenta à emergência da dis-posição que funda a continuidade prática do querer.

Em que medida então se dá a reciprocidade como modo de partilha de sentidos entre os entes extencionais? Para tanto, é preciso atermos à imersão ao próprio des-velar, i.e., ao deixar-e-fazer-ver enquanto princípio de des-cobrir o Outro. Mais especificamente até, observar o modo como este nos vem de encontro pela descoberta. O que intentamos assim é enxergar o entre-inicial do próprio relacionar, considerando-o como o abrir-se do ser ao ser que se lhe estende também enquanto tal. Trata-se então de uma solidariedade mútua no sentido de emergir de uma fusão de horizontes dos entes? Não necessariamente. Se entendemos de antemão que o pôr-se-em-solidariedade como orientação ao bem é uma precedência ontológica, a abertura é então a emergência mesma da vontade inicial que faz operar a relação. Se a condição de satisfação ou o que aqui tomamos por encontrar-se não se dá na ação mas no movimento que a antecede, temos então que o movimentar-se da ação especificamente comunicativa é o querer operante da relação nos termos de um para-o-outro. E movimento no sentido de uma primeiridade que lhe é concernente, i.e., como aquilo que direciona ao outro. Partindo dessa perspectiva, reflitemos:

\footnotetext{
o aberto e sua abertura são um caráter essencial do ser e só podem chegar a ser experimentados no saber inicial. Na medida apenas em que o homem histórico se essencia na ligação com o ser do ente, sua apreensão, isto é, a apreensão assumida pelo homem se estende até o desencobrimento. Só o homem apreende um aberto. Sem a manutenção da ligação rigorosa entre $\alpha \lambda \eta \theta \varepsilon \iota \alpha$ [desvelar] e a abertura, a essência do aberto marcado pela história do seer nunca pode ser pensada de maneira justa em relação à essência. (HEIDEGGER, 2013, p. 14-15).
}

Percebam que há nisto um ponto ao qual não atentamos ainda: o aspecto de historicidade na emergência ontológica do ser. $\mathrm{Ou}$, para aclararmos ainda mais, a transição da vivência pura à constituição de um portar-história. A própria noção de aí, como Heidegger a sugere, pressupõe a clareira inicial do aberto ${ }^{18}$, mas não necessariamente como o intencionar a outrem a partir dessa abertura. Pelo encontrar-se do que se vê então aí, operamos o abrir-se do ser àquele ser que se nos é exterior até o ponto de deixarmos e fazermos ver a emergência

${ }^{18}$ Cf. HEIDEGGER, Martin. O acontecimento apropriativo. - trad. Marco A. Casanova -, Rio de janeiro: Forense; Alemanha, 2013, p. 209 
mesma de um construir de sentidos. Porque, sendo, instituímos nosso existir para-comoutrem. Mas percebam que o aspecto mais histórico dessa abertura nos permanece por algum motivo velado, por não enxergarmos ainda o entre-inicial que funda ontologicamente essa transição. É preciso, portanto, compreender a partir de que princípio configurativo passamos a portar uma historicidade (pelo próprio intencionar) no sentido de nos contituirmos enquanto entes no-mundo.

Em primeiro lugar, observemos o seguinte: portar história pressupõe não exatamente a reciprocidade dos entes como tal, mas nesta, aquilo que emerge e se deixa inserir à continuidade enquanto tradição. Noutros termos, há uma sequencialidade daquilo que se mostra como resultado do relacionar com-e-para, no sentido de uma permanência temporal à lugaridade em que se dá inicialmente a relação. Por exemplo, do próprio encontro relacional, engendramos sentidos a ponto de se fazerem entendidos e, por esta razão, se inclinarem à dimensão histórica como um saber tradicional. Percebam então que tratamos aqui de um modo singular de pôr-se-a-comunicar, o qual trataremos simplesmente por [in]communis, i.e., a permanência do estar-em que orienta à comunidade que se faz em volta da partilha mesma. Este in-comunicar, de sua vez, só pode ser compreendido em seus aspectos mais ontológicos se o observarmos enquanto princípio operativo do voltar-se-a-algo comum aos entes relacionais e ver-se ao largo deste. Nesses termos, tratamos então a respeito de uma constituição existenciária que diz respeito a um estar-em fundante de uma comunidade que se apresenta como condição de possibilidade ao continuar de si em uma dimensão histórica.

Até aqui, histórico é tido nos termos de uma inserção espacio-temporal daquilo que emerge de nosso partilhar-com-outrem. Mas se não observarmos o modo como se dá a própria partilha pressuposta na relação, cairemos na ingenuidade de considerá-la tão só na condição de subexistência do social.

Percebam que a dimensionalidade do prático se apresenta menos como a emergência do eu-posso do que enquanto orientação maior da circunstância relacional. Por exemplo, verse-junto-a não é o mesmo que poder-estar-presente, posto que a união pressuposta no estar em reciprocidade implica necessariamente o querer nos termos fenomenológicos que aqui propomos. Pode-se até refutar a este respeito quanto à condição de satisfação da vontade primeira. Sobretudo naquilo que concerne a impossibilidade do próprio querer enquanto tal ser preenchido por aquilo que lhe é de mais praticável na essência. O que deve permanecer claro, no entanto, é o fato de que o princípio do relacionar-com-o-outro não se dá nos parâmetros de poder- $a$, mas aprioristicamente enquanto vontade que em si não traz a 
necessidade de eficácia garantida quanto àquilo que lhe é de prático. Isso não faria do comunicar uma dinâmica meramente fática, no sentido de se orientar tão somente a partir de um querer sem devir? Em absoluto.

De início, é preciso compreender que o telos do fenômeno comunicacional, na medida em que sustenta a compreensibilidade do ser dos entes pelo sentido, será sempre um primado em relação ao que lhe é de fim último. Ou, para aclararmos ainda mais, o querer tem no Agathon (o Bem) a forma precedente do próprio orientar-se- $a$, até o ponto de se apresentar na condição de essente ao ser. Segundo porque, nessa precedência mesma, o ser não entrega-se ao jogo do abrir-se simplesmente porque há uma finalidade ao próprio querer. Pois nesse sentido, o telos da vontade se mostra como o solidário que é primado ontológico.

Se essa precedência de que tratamos aqui é o mais essencial do ser que nos institui existenciariamente, por certo o tipo de orientação ao comunicar tem então de ser outro. Isso porque, se bem é o que se situa já em-nós, o direcionar-se-ao-outro enquanto ser que se abre às possibilidades tem de seguir um caminho diferente. Por exemplo, considerando que o bem é uma constituição existenciária de nosso ser mais essente, sua finalidade última quanto a estar-para-outrem deve se orientar pelo encontrar-se que funda a relação em seu aspecto metafísico. Isso não seria, no fim das contas, apenas otimismo quanto ao fato de não haver na abertura do ser quaisquer inclinações ao mal? Evidentemente que não. E por duas razões em específico: primeiro porque o mal, tomado em seu aspecto ontológico, nada tem que ver com uma manifestação antípoda ao bem. Nesses termos, mal é o cadere do eidos do Agathon, i.e., a de-cadência que se apresenta como abertura a possibilidades outras que não o bem que já nos é de saída essente. Segundo porque, de modo geral, o de-cair é o estar-em-jogo de um ser que se abriu àquilo que não está em consonância com o solidário a partir do intencionar-ooutro.

Percebam que aqui compreendemos o ser dos entes como o dis-por que tem já por primado o bem solidário. Mas nada foi dito ainda a respeito do que há de mais singular no encontrar-se quanto aos termos dessa solidariedade. Ou, precisamente, em que medida a relação entendida como princípio configurativo do comunicar pode ser observada como um "devotar-se-ao-outro"19. Para que esse estado de devoção passe a operar no sentido ontológico de um estar-para, o primado do ser enquanto bem fundante deve se abrir à responsabilidade para com este Outro que nos vem de encontro. Isso não é o mesmo que inferir a respeito de

${ }^{19}$ Cf. LEVINÁS, Emmanuel. Entre nós: ensaios sobre a alteridade. Petrópolis, RJ: Vozes, 1997, p. 18. 
uma fenomenologia da eticidade em vez de uma ontologia fenomenológica nos termos de uma especificidade comunicacional ao ser? Não necessariamente. Mas antes de nos atermos ao aspecto responsável da dis-posição, temos que compreender por último a forma como se dá o princípio da abertura e do encontrar-se. Sobretudo no que respeita à maneira como o ser-deoutrem nos chega ao intencionar.

O mais essencial no deixar e fazer ver do humano nos chega em forma de uma racionalidade que é condição inclusive ao intencionar. Tratemos aqui a respeito de um tipo singular de bem racional, i.e., uma espécie de "inteligibilidade da bondade" ${ }^{20}$, ou, se quisermos estender essa noção, um ver-se defronte ao entre-início do bem. Há duas dimensionalidades que podem nos servir como ponto de partida: observar o modo como o Outro se nos apresenta e, disto, como podemos lhe comunicar o que há de essente no ser nosso que se abriu às possibilidades do relacionar. Para que o encontrar-se seja a emergência mesma da abordagem, é preciso antes que o ser fale a outrem as condições de sua abertura. Que é este falar? De saída, nada tem ele que ver com qualquer princípio configurativo do comunicar, mas tão somente com o expressar-se do ser que se dis-pôs à constituição da clareira (Lichtung) ${ }^{21}$. Entendemos expressão aqui como sendo o sentido inicial do ser, que ainda não se vê em condições de sustentar a compreensibilidade do relacionar, mas que é já um início para tal.

Quando o ser dos entes em extensão se situa no $\operatorname{limiar}^{22}$ do estar-em e pôr-se-a que institui o mais essencial do in-comunicar, a clareira inicial da relação se mostra já como a instituição do existir na e pela comunicação. Sendo assim, para se ver em, é preciso que o início do abrir-se se dê nos termos de uma invocação, pois é "enquanto próximo que o homem é acessível. Enquanto rosto" ${ }^{23}$. Isso a que Lévinas trata como sendo Rosto é o presentar-se-a que se mostra à clareira instituída pelo ser dos entes. Percebam então que a própria noção de intencionalidade se torna agora o princípio de direcionar-se à invocação do Rosto, como se este nos viesse de encontro pelo mostrar-se-de-si, que se dá tão somente enquanto Rosto. De saída, a impressão que fica é que o direcionamento de nossa intencionalidade limita-se ao já dado pelo Rosto de outrem, sem que haja necessariamente o

\footnotetext{
${ }^{20}$ Cf. Id., ibid., p. 292.

${ }^{21}$ Cf. HEIDEGGER, Martin. Ser e tempo. - 10. ed. - Petrópolis, RJ: Vozes, 2001.

${ }^{22}$ Como veremos mais adiante, essa noção de limiar é considerada aqui menos como uma instância que separa do que, propriamente, um estado de passagem e constante devir que funda existenciais outros ao ser que se abriu às possibilidades. Pois, sendo, este nunca é de fato, visto sua constante peregrinação enquanto ser mesmo.

${ }^{23}$ Cf. LÉVINAS, 1997, p. 30.
} 
pasmo inicial do próprio encontrar-se. Mas não é disso que trata essa noção. Observemos então o seguinte:

\begin{abstract}
o Rosto não é absolutamente uma forma plástica como um retrato; a relação ao Rosto é, ao mesmo tempo, relação ao absolutamente fraco - ao que está absolutamente exposto, o que está nu e que é despojado, é a relação com o despojamento e, por conseguinte, com o que está só e pode sofrer o supremo isolamento que se chama a morte; por isso, há sempre no Rosto de Outrem a morte e, assim, de certa maneira, incitação ao assassinato, tentação de ir até o fím, de negligenciar completamente a outrem - e, ao mesmo tempo, e esta é a coisa paradoxal, o Rosto é também o ‘Tu não matarás'. (LÉVINAS, 1997, p. 144).
\end{abstract}

Com isso, desvelamos uma dimensionalidade um tanto diferente ao princípio do comunicar. Reflitemos: nossa consciência, enquanto ato, dirige-se ao mais essente do mostrarse do Outro, i.e., vai de encontro à presentação sua na condição de Rosto. Mas esse dirigir-se$a$, nos termos como Lévinas o trata, encerra em si uma postura singular para com outrem que se nos apresenta como tal. Por exemplo, ao ver-se $n u$ diante de nosso intencionar mesmo, a presentificação do Outro exige de nós o mover-se responsável como forma de encontrar-se, tendo nisso o início de uma inteligibilidade ${ }^{24}$ e, portanto, de sentido no-mundo. Mas percebam que nesse começo de relacionar, o direcionamento que nos faz ir-de-encontro se apresenta menos como o preenchimento da vontade originária ${ }^{25}$ do que, propriamente, enquanto pasmo que se mostra não necessariamente à semelhança operativa do Bem. Mas o agir responsável não é já um princípio configurativo do próprio Agathon? Não exatamente. O ver-seresponsável-por é apenas um aspecto à clareira aberta pelo ser e não dis-por primeiro que a configurou enquanto tal. Ou, para aclararmos, responsabilidade é a postura que nos veio como manualidade a partir do então aberto pelo ser. Disto, atentemos então ao que se segue:

\begin{abstract}
ensaiei uma fenomenologia da socialidade a partir do rosto do outro homem, lendo, antes de toda mímica, na sua retidão de rosto, uma esposição sem defesa à solidão misteriosa da morte, e entendendo, antes de toda expressão verbal, do fundo desta fraqueza, uma voz que comanda, uma ordem a mim significada de não ficar indiferente a esta morte, de não deixar outrem morrer só, quer dizer, de responder pela vida do outro homem, sob pena de se fazer cúmplice desta morte. (LÉVINAS, 1997, p. 198).
\end{abstract}

O que há de mais singular nessa afirmação de Lévinas é que, a partir do presentar-se enquanto Rosto, o Outro nos chega de encontro como fragilidade e violência em potência em

\footnotetext{
${ }^{24}$ Cf. Id., ibid., p. 143.

${ }^{25}$ Essa noção é aqui entendida nos termos de um querer-puro, i.e., fundante ao próprio intencionar.
} 
seu aspecto mais ôntico. Seria então esse mostrar-se frágil em relação ao $S i$ que desperta em nós o agir solidário? Em absoluto. Pois reflitemos a este respeito: se intencionamos o Outro, independentemente do modo como este se nos apresenta ao encontro, é porque dis-pomos já ao querer originário da relação. Até esse ponto, o que nos orientou foi menos o ver-se responsável-por do que, propriamente, a vontade que nos pôs em continuidade de relacionar. A clareira, portanto, foi previamente instituída em relação à responsabilidade. Mas percebam que, ainda assim, a epifania do Rosto é uma precedência do abrir-se a este como tal. Nesse sentido, se intencionamos o Outro é porque o mostrar-se de seu Rosto nos foi então revelado. Mas isso ainda não explica a razão de abrir-se ao intencionado em que desvelamos o presentar-se do Outro. Tampouco o modo como se dá os termos da condição de satisfação da intencionalidade, i.e., o encontrar-se em sua essência.

Uma inquietação permanece: com o já exposto, a impressão que fica é que o dis-porse-a só é possível nos termos de uma presentação epifânica do Rosto de outrem. Em linhas gerais, é equivalente quanto a afirmarmos acerca da impossibilidade de uma manifestação mesma do fenômeno comunicacional quando da ausência de um não-eu. Se isso se mostrar verdadeiro, o princípio essente do comunicar é um querer sempre prático diante da presença do Outro que nos faz atender a essa vontade originária do ser nosso que se abriu às possibilidades.

Para que esses pressupostos componham então uma totalidade de sentido, temos de explicar o modo como se dá a abertura em consonância com os parâmetros da fenomenologia do querer que propomos inicialmente. Se compreedermos o aspecto mais ontológico do abrirse do ser em relação à vontade primeira que lhe institui, será possível tratar da episteme jornalística quanto a seu saber-fazer e que pertinência tem isso que ver com o fenômeno comunicacional. Mas por hora, atentemos em observar até que ponto o querer se apresenta como o mais essente do ser que se comunica em que medida se dá a peregrinação nossa - por assim dizer - entre a vontade mesma e o encontrar-se que nos orienta ao Outro.

\subsection{Do Querer Originário (ou Do Diálogo como Ato Essente ao Comunicar)}

Até aqui, tratamos de observar algumas das singularidades que dizem respeito ao ato consciente do intencionar. E estendemos esse tipo de ação à figura do alheio, especificamente 
no que diz respeito à condição de satisfação (para usar a expressão searliana) quando do encontro nosso pela intencionalidade. Mas pouco foi analisado quanto ao modo como se dá o próprio relacionar-com-outrem e até que ponto passamos de mero ato consciente à produção sofisticada de sentidos no-mundo sob a orientação do comunicar. Em primeiro lugar, entendemos já que o Outro nos vem de encontro quando o percebemos ao intencionarmos aquilo que, pela manualidade mesma, se mostra como mais epifânico de início, i.e., seu Rosto. Essa revelação singular, que é sempre pasmo inicial, se apresenta também pelo deixar-efazer-ver que o ato consciente des-vela enquanto princípio do relacionar. E nesses termos nos vemos responsáveis pela seguridade desse Outro, no sentido de, ao intencionarmos seu Rosto, o tipo de postura nossa para com este se oriente tão-só pela solidariedade que nos funda de antemão na condição de ser que se abriu às possibilidades do encontrar-se.

A esta altura, nos parece seguro inferir que os fundamentos ontológicos desse tipo de fenomenologia da vontade nada têm que ver com a constituição mesma nos termos de uma pulsão ou impulso que se voltam à liberação ${ }^{26}$ de quaisquer forças. Nesse sentido, quando tratamos de um querer, evidentemente não o observamos à luz de uma páthe, muito embora seja sim um tipo específico de paixão. Mas percebam que paixão, no modo como então a consideramos, não é um "distúrbio" ${ }^{27}$ precedente ao ato mesmo de intencionar, mas ela própria como constituição existenciária do modo como o fenômeno comunicacional se nos apresenta enquanto instituição nossa frente ao ser que se dis-pôs ao abrir-se de si. Isso porque, em termos gerais, o sentir da paixão é já o mais essente da intencionalidade que orienta à revelação de outrem. Diante disso, portanto, não se pode dizer a respeito de uma pulsão orientadora do agir, porquanto tratamos aqui do tipo de existencial que se apresenta como primado à própria ação. E também não lidamos com uma dimensionalidade moral do comunicar, pois as reduções eidéticas até o momento nos direcionaram tão somente ao mais especificamente fenomenológico do querer enquanto princípio configurativo da comunicação.

Se o sentir da paixão nada tem que ver com o liberar das emoções, em que medida então este querer se faz originário no sentido de instituir o próprio comunicar? De início, consideremos a ideia de que a vontade pura é uma emergência mesma do intencionar em seu sentido mais noemático, i.e., tendo no objeto intencionado a orientação de sua motivação enquanto tal. Ou, noutros termos, tendo na manifestação epifânica do Outro a razão de uma

\footnotetext{
${ }^{26}$ Vista aqui no sentido equivalente ao de apátheia.

${ }^{27}$ Ver GILL, Christopher. A escola no período imperial romano. In: INWOOD, Brad (Org.). Os estóicos. - Trad. Raul Fiker -. São Paulo: Odysseus Editora, 2006, p. 44.
} 
continuidade - por assim dizer - do próprio ato consciente. Da revelação do Outro enquanto dimensão intencionada à vontade de manter com ele um entre-início relacional, há ainda algo não visto a ponto de enfim compreendermos a totalidade ontológica disso a que tomamos por comunicação.

Reflitemos, então. Em vez de tratarmos da paixão como o aparente da autodestruição $^{28}$, nos aproximamos mais e mais, pelo deixar e fazer ver, do eidos que lhe é fundante. Ou, noutros termos, avistamos agora a dimensionalidade do amor enquanto encontrar-se diante do Outro. Mas ao observarmos a amabibilidade do querer não estamos já a passos curtos de uma irracionalidade nociva ao comunicar, até o ponto de o dirigir-se-a se apresentar como aquilo que está entregue ao sentir? Em primeiro lugar, amar é observado aqui nos termos do des-velar, i.e., sob a perspectiva de ver-se o ente à clareira e instituí-la a ponto de seu ser abrir-se à possibilidade do revelar-se do Outro. E revelação, portanto, nada é senão que a motivação pelo encontrar-se com outrem que nos serve ao intencionar. Segundo porque o sentir nada tem que ver com a causalidade das coisas mesmas, mas com o despertar que a própria intencionalidade orienta quando do mostrar-se epifânico do não-eu. Por exemplo, se sentimos o Outro, é porque este já se nos apresentou como tal à possibilidade do abrir-se no momento em que o intencionamos na condição de um presentar-se a nós.

Resta ainda uma inquietação: se compreendemos o querer na condição de vontade pura no sentido de fundar a própria intencionalidade que nos direciona a algo, em que medida essa constituição existenciária do ser é inevitável a ponto de instituir o encontrar-se? Ou, noutros termos, seria então o comunicar a emergência mesma dessa inevitabilidade do querer primeiro? Isso nos dá dois direcionamentos possíveis. Um que diz respeito à dimensionalidade prática do querer e outro que trata da necessidade de ver-se compelido a preenchê-lo no sentido de entregar-se às possibilidades de sua satisfação. Por hora, centremos nesse primeiro, já que o segundo é tema a ser abordado no próximo tópico deste trabalho. Isso porque é preciso observarmos a razão de haver no próprio aspecto prático do querer, algo que efetivamente nos desperte ao atendimento seu enquanto vontade mesma. Do contrário, o elemento fenomenológico da vontade com o qual lidamos agora ver-se-ia sempre ao largo da causalidade quando da presença do Outro. Evidentemente não é nessa direção que caminhamos.

${ }^{28}$ Cf. GILL, 2006, p. 63. 
A dimensionalidade eidética do querer, em seu sentido mais fenomenológico, se dá também nos termos de um acreditar-no-que-virá. Percebam que, pelo mostrar-se epifânico do alheio que nos vem-ao-encontro, acreditamos de antemão na possibilidade de que tenha o Outro algo no sentido de preencher aquilo que em nós se mostra como ausência mesma. Aqui, a noção de preenchimento já não é mais equivalente ao encontrar-se ${ }^{29}$, pois é tida enquanto um estar-ausente que se nos é prévio. Se pelo presentar-se de outrem nos movemos ao intencionar das possibilidades que isso implica, por que nos dis-pomos à crença de que somos, sem o Outro, um constante vazio?

Disto, atentemos à noção de que a completude do $S i$ sempre se dá nos termos do encontro com o não-eu, até o ponto de haver nisso a razão do comunicar em sua essência. Por exemplo, o querer do especificamente comunicacional só pode ser entendido enquanto tal se o tomamos como a crença fundante que é sempre orientada à possibilidade do bem de algo futuro. Do contrário, passaríamos toda vez ao largo do presentar-se do Outro que nos vem-deencontro. Mas percebam que a crença não se volta necessariamente à existência de um bem prático, mas tão só ao dever ${ }^{30}$ de alcançá-lo caso queiramos a pacificidade à qual o comunicar está orientado. O que essa paz pressupõe, evidentemente, é a responsabilidade do próprio irao-encontro, no sentido não necessariamente de uma completude, mas de uma unicidade ${ }^{31}$ daquele que, no sair-de-si, se apresenta como único. Pois somente o único é "absolutamente outro" ${ }^{32}$, em que unicidade é tida então nos termos da própria paixão-por.

Cabe aqui uma ressalva: essa unicidade de que trata Lévinas nada tem que ver com a dimensionalidade do sentir orientado por um estar-enamorado-por. É, na "essência impassível do ser, e no diverso genérico do objetivo, a condição da possibilidade do único" (id., ibid.). Ou, noutros termos, a singularidade do intencionar quando do instante em que comunicar se torna questão de pacificar a instituição do existir. Em seu sentido mais essencial, o estar-em-paz é a emergência mesma da relação em que nos vemos para-o-outro, i.e., quando nos dis-pomos à sua alteridade enquanto único. Amar, ou o essente do querer, é uma operação lógica pela qual des-velamos o verdadeiro. E que é o verdadeiro? Nada senão o estar em não-violência pelo comunicar.

\footnotetext{
${ }^{29}$ Embora não tenhamos ainda explicado a dimensionalidade ontológica disso a que aqui tomamos por encontrar-se, acreditamos ser pertinente ao menos situar essa noção em relação à intencionalidade. Essa proposta será melhor apresentada no tópico seguinte deste trabalho.

${ }^{30}$ Cf. BRENNAN, 2006, p. 299.

${ }^{31}$ Cf. LÉVINAS, 1997, p. 246.

${ }^{32}$ Cf. Id., ibid.
} 
Em termos gerais, portanto, o querer que serve de princípio operativo ao comunicar é tido nos termos de uma proaíresis, i.e., uma vontade racional que orienta à ação do intencionar como modo de pacificar nosso existir. Amar, ou o sentir da paixão, é a precedência do eu-posso no sentido de ver-se em livre-arbítrio. Por isso é condição de possibilidade no abrir-se do ser, uma vez que poderíamos simplesmente passar ao largo quanto ao presentar-se do Outro. Isso é o mesmo que afirmar na impossibilidade de um determinismo à comunicação? Não necessariamente. Nos parâmetros em que a observamos agora, já não se trata de intencionar o Outro como forma de determinar a existência nossa nomundo, mas de fazer do próprio comunicar a condição de possibilidade à abertura do ser que, sendo, institui assim seu existir.

No modo como esta vontade se apresenta em seu estado mesmo de vis, i.e., uma ânsia que "se mantém velada mesmo como a vontade de vontade e aparece de início como razão, espírito, vontade do amor" ${ }^{\text {"33 }}$, é no princípio do relacionar que encontra a si própria enquanto des-velamento no abrir-se do mais essencial no ser quando do vis-ar o Outro.

Percebam que, ao observarmos as potencialidades do comunicar tão somente nos termos de uma representação, eliminamos de antemão as condições quanto aos tipos singulares de afetividade que estão pressupostos no estar-para pela responsabilidade. E do mesmo modo como comunicação nada tem que ver com o representar de si a outrem, também não se reduz à pré-concepção que fazemos do intencionar. Ou, noutros termos, o ver-se responsável-por-outrem é menos a representação do intencionado no-mundo do que, propriamente, o amar não-concupiscente que também nos dis-põe ao relacionar. Trata-se então do eis-me aqui do in-comunicar. Se nesse tipo de situação, em que dis-pomos ao abrirse-para-o-outro, nos situamos mutuamente num encontro em que fundam-se os horizontes nossos, que princípio então configura a sustentação da compreensibilidade na própria clareira? Em parâmetros equivalentes, que é necessário à emergência do sentido quando nos pomos já a comunicar?

Até aqui, tratamos de observar o mais essencial da intencionalidade quando entendida na condição de princípio fundante ao comunicar. Mas nada foi dito ainda em relação ao dialogar enquanto sustentáculo do sentido à abertura do ser para-outro. Que é esse pôr-seem-diálogo como atributo configurativo do sentido emergente no fenômeno comunicacional?

${ }^{33}$ Cf. HEIDEGGER, 2013, p. 121. 
Em primeiro lugar, é preciso que compreedamos o telos desse estar-em da comunicação enquanto instância dialógica se quisermos enxergar quais os limites seus em relação ao fenômeno originário ${ }^{34}$. Por esta razão, cabe questionarmos se o diálogo é tido na abertura do comunicar como órganon que sustenta seu funcionamento ou se, pelo contrário, é ele próprio um estar-em-sustentação nos atos em si comunicativos. Partamos do pressuposto de que o aspecto mais aparente do di-a-logar se dê na manifestação da linguagem, que não é apenas articuladora de sentidos, mas serve também como estrutura da instância na qual nos poremos ao encontro do Outro.

Se a linguagem é já a estrutura e se o diálogo assegura o próprio relacionar, o que então permite que nos entendamos uns aos outros numa instância comunicativa? A operação do comunicar é determinada pela linguagem ou, eo ipso, encerra o atributo essente do que institui a própria estrutura estruturante? A princípio, essas questões fogem ao escopo ontológico deste trabalho. Mas caso queiramos observar o diálogo na condição de atributo à comunicação, os termos de uma fenomenologia da linguagem em muito pode nos auxiliar. Sabe-se que linguagem enquanto tal não é garantia de entendimento entre nós ${ }^{35}$, tampouco que as relações no abrir-se do ser pelo comunicar perdurarão simplesmente por compartilharmos em comum um sistema sofisticado de símbolos. Noutros termos, se a linguagem é um tipo singular de estruturação do simbólico a partir de códigos convencionalizados no estar-em do comunicar, o que funda a estrutura mesma?

Em primeiro lugar, consideremos que a precedência do estruturar de qualquer linguagem se dá nos mesmos termos de uma intencionalidade pelo querer que é princípio à sustentação da compreensão. Por exemplo, se nos vimos na urgência de formular um sistema de códigos pelo ato mesmo do estar-em-diálogo, é porque de saída nos entregamos à crença do que há de mais prático no intencionar-o-outro enquanto possibilidade ao comunicar. Nesse sentido, o que reificamos no di-a-logar é menos a estrutura termitente do estruturado do que a emergência mesma do querer-linguagem. Esta última, nos termos de como a propomos, é também uma constituição existenciária à emergência do intencionar quando da epifania do alheio. Ou, para aclararmos, o querer-linguagem é a instituição, pelo abrir-se do ser, das possibilidades da relação responsável e pacificada. Quando nos pomos em diálogo com-e-

\footnotetext{
${ }^{34}$ Esse originário é aqui compreendido nos termos de uma fundação mesma ao próprio comunicar, que, em termos gerais, trata-se do intencionar a partir do presentar-se do Rosto de outrem.

${ }^{35}$ Entendimento aqui visto sob a ótica de uma dimensão normativa, i.e., a compreensão que se dá no e para o outro numa solidariedade mútua.
} 
para-o-outro, estamos já estruturando existenciariamente as condições da abertura que nos funda enquanto sujeitos ${ }^{36}$. Percebam que agora o termo vivente já não nos serve para dar conta da complexidade que se forma quando lidamos com os existenciais do ser-aí, pois o existir se dá então nos termos de uma fundação no e pelo relacionar comunicativo.

Questionamos, há pouco, a respeito de uma instrumentalização do ato de comunicar a partir do mecanismo do diálogo. Não há como inferir que seja este um mero instrumentum da linguagem, posto que é no ato mesmo do dialogar que se estrutura o simbólico do fazerlinguagem. Do mesmo modo como não é o dialogar na condição de vontade que se mostra enquanto órganon no ato comunicativo, mas tão somente a ideia de que deve nele haver benefício entre os entes cujo ser se abriu às possibilidades do in-comunicar. Acaso não é a incompreensão, também, um sentido produzido, i.e., o do não entendimento? Sua razão primeira é estabelecer as condições do desejo de estar-com-e-para o Outro e não, especificamente, a garantia de que haverá nisso uma relação permanente. Removemos assim a noção de garantia do ato dialógico, do mesmo modo como também o fizemos quanto à obrigatoriedade da partilha de símbolos estruturados linguisticamente. O que então nos resta a ponto de considerar isso que tratamos aqui por di-a-logar e qual sua pertinência com o mais essente do comunicar?

Resta, portanto, a coisa que tem vontade. Ou, para aclararmos, o mais essencial do ser que intenciona à abertura no sentir do querer. E disto, uma vontade mesma de enxergar no Outro alguém a quem se supõe também desejar. A esse respeito, Rousseau (1762) ${ }^{37}$, trata de paixões, i.e., essa essência que nos tirou as "primeiras vozes" (Id., ibid., p. 163) ${ }^{38}$, em contraste com a necessidade, que ditou os primeiros gestos. É então que sua noção de paixão penetra o cerne da de necessidade moral, que conduz ao desejo de nos aproximar-de. Essa noção, a princípio, em nada difere dos termos aqui propostos quanto a uma fenomenologia do querer, embora não tenhamos ainda observado as fronteiras morais do próprio intencionar-ooutro.

$\mathrm{Na}$ condição de entes cujo ser se abriu às possibilidades do intencionar-para, nos vemos separados quando estruturamos linguagens próprias a ponto de fortificar laços entre

\footnotetext{
${ }^{36}$ A noção de sujeito, em respeito à lógica formal a que seguimos aqui, será aprofundada apenas no próximo tópico deste trabalho.

${ }^{37}$ Embora a obra com a qual se teve acesso seja uma edição traduzida do original francês e publicada em 1978, também optou-se aqui por citar o ano de sua primeira circulação.

${ }^{38}$ Paginação referente à obra com que se teve acesso.
} 
nossos semelhantes. A princípio, essa postura encerra em si a contradição quanto a um estarpara-o-outro. Pois nos apartamos com o objetivo de nos unir. E não foram necessidades biológicas, como atenta Rousseau, que nos puseram em vontade de relacionar com esse outro, mas "o amor, o ódio, a piedade [e] a cólera" 39 . Sendo assim, o querer se apresenta também como motivo de fala ou na emergência mesma do mais essente no estar-para que nos põe a desejar-a. E disto, chegamos à ideia de entendimento:

\begin{abstract}
como os primeiros motivos que fizeram o homem falar foram paixões, suas primeiras expressões foram tropos. A primeira a nascer foi a linguagem figurada e o sentido próprio foi encontrado por último. Só se chamaram as coisas pelos seus verdadeiros nomes quando foram vistas sob sua forma verdadeira. A princípio, só se falou pela poesia, só muito tempo depois é que se tratou de raciocinar. (ROUSSEAU, 1978, p. 164).
\end{abstract}

Noutros termos, da intencionalidade das coisas, des-velamos o verdadeiro emergente para então construirmos o sentido que mais tarde sustentará parte da compreensibilidade do já intencionado. Se, de um lado instituímos esse entender-a-respeito-de à luz de uma linguagem fundante pela doxa de nosso relacionar, por outro, também o fazemos quanto ao criarlinguagem a partir da institucionalização gramatical. A questão que se coloca agora é a de compreender que essa tradição de valores partilhados e aceitos em comum pelo di-a-logar é também resultado da proaíresis que, na emergência do intencionar, nos orienta à relação.

Criamos então palavras. Estas, à medida que são partilhadas pelo querer nosso de estar-com-e-para-outro, se apresentam como condição às instâncias possíveis do comunicar. Mas isso não significa dizer, por sua vez, que os sentidos circulados estejam nas próprias palavras a que chegamos pela estruturação em códigos do simbólico no-mundo. Pois no ser, e tão somente assim, habita o sentido primeiro que elas encerram. Aceitamos os valores e concordamos com as regras conquanto parta da emergência no abrir-se do ser o sentido orientador do entender. Do contrário, compreenderíamos sem muitas dificuldades os tipos vários de estruturação linguística, já que quaisquer fundamentos semânticos estariam prontos e não-dependentes das atribuições a que chegamos pelo dialogar. Mas, se os sentidos não estão nas palavras e sim no mais oculto do ser que nos permite então situá-las no-mundo, é também possível concluir que aquilo que dizemos quando do dialogar-com-o-outro não seja

\footnotetext{
${ }^{39}$ Cf. Id., ibid., p. 163-164 - Grifo nosso. Agora que o pensamento rousseauneano foi devidamente aclimatado à conjuntura em que se deu, adotar-se-á, deste ponto em diante, as referências concernentes à obra com a qual se teve acesso.
} 
um conjunto de palavras? Se a paixão, para usar a premissa rousseauneana, nos move ao diálogo, a que, então, o dialogar nos move?

Tratamos antes da noção de relação enquanto emergência do intencionar-o-outro na medida de uma precedência à abertura do ser. Mas se as proposições, sentenças ou simplesmente orientações pontuais que sugerem uma inteligibilidade não forem necessariamente resultado do que enunciamos, o que dizemos uns aos outros, afinal? Chegamos assim ao seguinte: somos compelidos pelo querer na emergência do intencionar-ooutro e que se nos apresenta pela urgência de conhecer quem este é para nós. Criamos, em conjunto, um sistema de códigos que desse conta dos símbolos que articulam sentidos e deste modo o di-a-logar nos pôs em relação. Mas, se reduzindo eideticamente o diálogo tenha nos restado o querer puro do comunicar, este fenômeno não teria condições de se manter enquanto tal caso também não houvesse um segundo desejo, qual seja, o de atender ao primeiro. Noutros termos, trata-se do querer que opera pela inteligibilidade do comunicar a se interpor no limiar de um desejar-conhecer e reconhecimento-de. Pois tão somente nos termos de um compreender-se-mutuamente que se faz operar a sustentação do entender pelo sentido na emergência do relacionar.

Retomemos as premissas rousseauneanas concernentes à paixão, no sentido de que a ligação que mantemos com o Outro a quem não conhecemos deve orientar-se pelos termos de um estar-em-pacificidade-com. Não havia, antes dessa vontade de se mover ao conhecer, qualquer tipo de fraternidade relacional na emergência do intencionar, pois a princípio, as coisas sustentavam-se a partir do arbítrio da força e da violência de uma inimizade em potência. E sem entendimento mútuo, atacávamos na esperança de nos defender ${ }^{40}$. Percebam que aqui o querer fundante enquanto primado do mover-se-ao-diálogo é o que dá sentido ao que somos pela noção mesma do in-comunicar.

O que entendemos até este ponto por comunicar não é meramente um proceder que se manifesta apenas pelo agir, mas uma constituição existenciária que se vê à emergência do encontrar-se. O tornar comum comungando (pelo próprio abrir-se do ser) se define não mais pela presença pensante do estar-consciente-de-si, mas pelo ver-se cônscio de co-existir com o Outro no-mundo. Fica então a questão de sabermos: se o diálogo não instrumentaliza o comunicar no sentido de fazer do ato mesmo uma simples dinâmica processual, o que faz

${ }^{40}$ Cf. ROUSSEAU, 1978, p. 174-175. 
operar para além da relação que estabelecemos uns com os outros? Até que ponto, portanto, há uma razão de ser dialógica enquanto telos e não estratégia ao comunicar?

Trata-se, afinal, de uma espécie de jogo tácito entre os entes cujo ser deixou-se abrir à condição do in-comunicar. E isso se dá, evidentemente, nos termos de uma instância ulterior em relação ao instituir da clareira. Mas percebam que, se a linguagem direciona as regras desse jogo a ponto de nos vermos incapazes de jogá-lo conquanto não partilharmos dos mesmos arcabouços simbólicos que previamente as definem ${ }^{41}$, esses princípios que nos orientam ao di-a-logar se fundariam apenas à medida em que codificamos o mundo?

Talvez seja mais pertinente agora questionarmos quanto à real possibilidade de tais princípios nos manterem no querer que funda a própria relação. Se a vontade originária nos fez saltar de uma imcompletude de sentido a ponto de alcançarmos novos horizontes quando do instituir da clareira, o que assegurou o desejo mesmo de estar-com e ceder-a, característicos desse existencial? Para tanto, é necessário compreender o modo como o aspecto mais normativo de nosso relacionar-com-e-para opera no sentido de dar coerência às relações que estabelecemos e mantemos mutuamente.

Até aqui, tratamos de um movimento de mudança na condição inicial do intencionar à reificação que se faz a partir de convenções que ordenam e codificam o simbólico numa linguagem comum aos entes cujo ser se dis-põe ao comunicar. Mas o reificar da linguagem não pode ser tido por mera representação de nossos atos de consciência enquanto condição primeira à possibilidade do abrir-se da comunicação. É necessário, afinal, essa constituição existenciária que tratamos por querer originário. Ainda que este oriente à compreensão de outrem pelo estar-em pressuposto no in-comunicar, o que fazemos de nossos pensamentos na condição de vontade mesma é menos sua representação material e linguisticamente estruturada do que o desejo de fazer destes parte da instituição do querer que nos move ao Outro.

Justamente por intencionarmos-o-mundo, temos na figura de outrem o ser que, no encontrar-se, sequencia a cadeia de sentidos que antes iniciamos a partir do dirigir-se-a. É, portanto, um instituir cíclico que não começa necessariamente com o que pensamos, parte à reificação e finda-se à compreensão por meio da linguagem estruturada. Se o que tomamos

\footnotetext{
${ }^{41}$ Cf. FERRY, 2007, p. 29.
} 
por real é uma espécie de medear que se interpõe em nosso agir pela relação, é pelo querer enquanto enfrentamento-do-mundo que nos dis-pomos à mutualidade participativa.

É esse mover fundante, nos termos como aqui o tomamos, que nos orienta ao mais essente do relacionar, i.e., à instituição que sustenta a compreensibilidade de sentido à abertura do ser dos entes. Mas regressemos à problematização primeira: saber em que medida o querer opera como fusão de horizontes pelo encontrar-se que nos põe em atendimento da vontade pura no comunicar. Noutros termos: basta o desejo desse estar-junto-a para que a performance comunicativa se estabeleça a ponto de instituir e fazer circular sentidos nomundo? Teremos de compreender então as dimensionalidades ontológicas desse encontrar-se na condição de dis-positivo se quisermos desvelar o eidos da vontade para além da noção de intencionar. Daí chegaremos às singularidades das formações sociais e que pertinência tem a comunicação que ver com o início de nosso viver civilizado.

\subsubsection{Do Encontrar-se enquanto Preenchimento do Intencionar (ou do Dis-positivo como Atendimento ao Querer Fundante)}

Até aqui, reduzimos eideticamente o fenômeno comunicacional até o ponto de termos já alguns direcionamentos específicos no des-velar de seu essente. Suspendendo os juízos nossos como forma de acesso originário ao eidos pretendido, chegamos à ideia de intencionar enquanto des-cobrimento da figura do Outro que nos vem-de-encontro numa epifania ôntica do presentar-se- $a$. Para que haja algum princípio ao relacionar-com-e-para, temos de nos dirigir ao re-velado se quisermos configurar com ele o início do comunicar. Mas percebam que nada foi ainda dito a respeito do que é a dimensionalidade do eu-posso implicada no ato mesmo do intencionar.

Reflitemos. Se a ação noética de direcionar-se a um objeto como ato consciente em relação a este é o entre-início do deixar e fazer ver, como então pressupor suas fronteiras enquanto praticabilidade na forma de primado ao próprio ato? Ou, noutros termos, que é este prático quando o compreendemos como condição de possibilidade ao preenchimento do próprio ir-ao-encontro-de? Em primeiro lugar, será pertinente tomá-lo enquanto fiat criador, i.e., um que-assim-seja a operar em conjunto com o ato mesmo de intencionar aquilo a que se dirige no-mundo. Vimos antes, que esse preencher-a é uma tomada de posição em relação ao 
objeto intencionado no sentido de a ele nos orientarmos, como num encontrar-se que institui a emergência de toda ação consciente. Mas esse fiat, enquanto razão prática, muito tem que ver com a vontade que opera em conjunto àquela mais originária em relação ao conhecer do que é já intencionado. Notem então que há agora a necessidade de se inferir a respeito de duas operações configurativas do querer, uma que diz respeito à vontade pura ${ }^{42}$, própria ao ser, e outra que trata do querer-satisfazer a vontade primeira. Este segundo querer nada tem que ver com uma vontade de segunda ordem, pois este opera tão somente por haver a fundação originária. Nesses termos, encontrar-se é a emergência da própria tomada de posição diante do fiat criador do intencionar.

A questão que fica, portanto, é a de saber em que medida o preenchimento do intencionar como razão prática é condição única ao início do comunicar. Se agora nos parece claro o fato de que encontrar-se é também condição de possibilidade à emergência do euposso na intencionalidade, bastaria então o presentar-se do alheio a ponto de nos movermos à relação? Para tanto, é preciso compreender que além da dimensionalidade prática do intencionar, há ainda outra que diz respeito ao mais axiológico de sua operação. Por exemplo, quando intencionamos o não-eu a partir da manifestação epifânica sua, o agir consciente nosso se volta à seguinte racionalidade: que ganhamos ao ir de encontro a ele? Nesse sentido, o Outro precisa ter em si algum valor que fundamente o querer originário que nos move a seu presentar-se. Ou, a título de síntese, tem ele de ser quisto pelo próprio querer nosso numa relação de fundamentação ao encontrar-se.

Mas valor, nos termos como o entendemos, é menos uma estratégia que orienta o agir do que o telos no estar-para-outrem que o relacionar pressupõe. Ser quisto então no sentido de mostrar-se enquanto possibilidade ao bem. Percebam agora que o encontrar-se na condição de vontade de atender a vontade pura é um dis-por que faz de nosso ato consciente o dirigir-se-a fundante do estar-em relação. Mas essa orientação nada tem que ver com a eficácia do entendimento, pois entender é também precedência junto ao intencionar. Sendo assim, o bem comum enquanto princípio configurativo do relacionar não traz em si um valor específico, mas se apresenta antes como o mais emergente do valorar pela intencionalidade. Por exemplo, não nos dis-pomos ao Outro simplesmente porque teremos nisso a eficácia garantida de conseguir algo de valor, mas o fazemos em vista de assumirmos de antemão a posição de que há no presentar-se-de-outrem aquilo que, enquanto bem, de algum modo nos

\footnotetext{
${ }^{42}$ Aqui, "puro" é entendido nos termos de um fundar-se a ponto de instituir algo existenciariamente.
} 
completará como seres que se abrem. Se é no abrir-se, portanto, que o ser-em se constitui existenciariamente, é no próprio dis-por que se dá a emergência mesma do preenchimento da vontade originária.

Até aqui, alguns aspectos carecem de explicação. Por exemplo, quais as implicações da dis-posição quando a entendemos como o encontrar-se do mais essencial do ser nos entes? $\mathrm{Ou}$, dito noutros termos, que ocorre ao ser no preencher daquilo que antes é intencionado? Sob essa perspectiva, observemos que à própria intencionalidade, somos entes cuja singularidade se presenta no mais recôndito do ser. Percebam que o presentar-se do objeto beira sempre o solipsismo de nosso pasmo inicial em relação a este, pois no mais epifânico de sua figura, não há garantia alguma de que nos dis-poremos ao encontrar-se junto ao Outro. Mas a partir do instante em que encontramos com o ser do ente que se nos apresenta no mais velado de sua manifestação, quais as implicações do relacionar quando consideramos a princípio sua dimensionalidade ôntica?

Em primeiro lugar, é preciso compreender que no próprio operar do dis-por, somos compelidos à vontade de atendimento da vontade originária. Logo, nos deixamos capturar pelo mais emergente do fiat criador pelo intencionar. Mas quando o ser dos entes está já à configuração do encontrar-se, este já não pode mais simplesmente se apresentar na condição ôntica daquele que intenciona. Evidentemente, o ser que se abre à possibilidades continuará des-velando o mundo quando do pôr-se-a-comunicar, mas entendam que algo aconteceu ao ente no instante mesmo em que deixou-se capturar pelo dis-positivo de satisfação do querer puro. Dizemos isso pelo fato de que ambos passam então a portar no próprio ser o constituir histórico de si num viver-em-conjunto. A este respeito, observemos o seguinte:

\begin{abstract}
a substância viva é o ser, que na verdade é sujeito, ou - o que significa o mesmo que é na verdade efetivo, mas só na medida em que é o movimento do pôr-se-a-simesmo, ou a mediação consigo mesmo do tornar-se outro. Como sujeito, é a negatividade pura e simples ou a duplicação oponente, que é de novo a negação dessa diversidade indiferente e de seu oposto. (HEGEL, 2002, p. 35).
\end{abstract}

Reflitemos então: se o que Hegel entende por negatividade é este manter-em-si o que é já $d e$-si, isso a que entendemos por dis-por ${ }^{43}$ não pode ser algo senão a forma não de-caída desse pressuposto, i.e., uma positividade. Nesse sentido, positividade - daí o termo dispositio enquanto étimo principal de dis-positivo - é a constituição transcendental do ser que saiu-de-

\footnotetext{
${ }^{43}$ Em alemão, o termo que aqui entendemos por dis-por, é tido por Verfügen, sendo seu étimo principal o verbo fügen, que significa juntar.
} 
si ao encontro do presentar-se do ser de outrem. Ou, noutros termos, negativo é o que se vê em repouso ${ }^{44}$ quanto à emergência mesma do ser na condição de sujeito. Mas percebam que o princípio do ver-se enquanto sujeito nada tem que ver com o devir do próprio ser. Por já estar $a i ́$, o ser do ente que se mostra agora como sujeito é a condição de possibilidade à instituição de seu existir a partir do portar-em-si do mais essencial daquilo que é histórico. Por exemplo, é pelo abrir-se à constituição do relacionar, que o ser constrói a historicidade que o próprio dispositio pressupõe:

\begin{abstract}
historicidade indica a constituição ontológica do 'acontecer' próprio [do ser-aí] como tal. E com base na historicidade que a 'história universal', e tudo o que pertence historicamente à história do mundo, se torna possível. Em seu ser de fato, [o ser-aí] é sempre como e 'o que' [..] já foi. Explicitamente ou não, [...] é sempre o seu passado e não apenas no sentido do passado que sempre arrasta 'atrás' de si e, desse modo, possui, como propriedades simplesmente dadas, as experiências passadas que, às vezes, agem e influem sobre [o ser-aí]. Não. [O ser aí] 'é' o seu passado no modo de seu ser, o que significa, a grosso modo, que [ele] sempre 'acontece' a partir de seu futuro. (HEIDEGGER, 2001, p. 48 - Grifo nosso).
\end{abstract}

Esse estar-em-pretérito do ser, pressuposto no pensamento heideggeriano, é o mais aparente da dimensionalidade prática do intencionar. Isso, evidentemente, no sentido de que o fiat criador do relacionar é a postura do assumir frente ao que está por-vir. E nessa tomada de decisão, presentificamos a possibilidade futura pelo in-comunicar a partir do abrir-se do ser. Percebam agora que a noção de dis-positivo encerra a positividade do deixar-a-si para se ver à clareira do rumar-a-outrem, que é o encontrar-se em sua totalidade eidética. Mas não tratamos aqui de uma espécie de abandono do ser enquanto íntimo. O sair-de-si não é a negação daquilo que nos é essente, pois o eidos de nossa condição mesma se dará sempre nos termos do pôr-se-a-outrem implícito no fenômeno comunicacional. O que então emerge do pôr-se-de-encontro?

Não lidamos mais simplesmente com o pre-encher de algo intencionado, mas com a urgência mesma do encontrar-se - que se dá no ser - quando nos comunicamos a ponto de engendrarmos o partilhar de sentido que se mostra enquanto princípio operativo do estar-emrelação. Mas não devemos compreender o dis-positivo simplesmente como uma amarra ao ser no sentido de deixar os entes que agora são sujeitos à deriva da instituição de seu próprio existir. Pois, se nos deixamos capturar, é porque, antes, o querer originário em nós já operou. E assim nos movemos a comunicar, porquanto a con-vivência à ausência do encontrar-se já

\footnotetext{
${ }^{44}$ Cf. Id., ibid., p. 37.
} 
não é mais possível agora que o ser dos entes se revelou na condição de sujeito portador de história.

Noutros termos, o que neste trabalho tomaremos então por comunicar é o acontecer do ser à emergência do aberto às possibilidades de estar-para-outrem. O princípio configurativo da comunicação enquanto um pôr-se a comungar até o ponto de criarmos as condições de um viver-em-conjunto, é já um tipo de invocação intencional da figura do Outro que se nos apresenta como alheio em seu revelar. E des-velando essa figura no mais íntimo de seu ser pelo comunicar, construímos os sentidos que são a pura constituição ontológica de nosso existir no-mundo.

Ao portarmos história ${ }^{45}$, deixamos o estado de seres viventes ${ }^{46}$ e passamos ao de sujeitos cujo ser permite-se capturar pelo dis-positivo do comunicar. Vivente, nos termos como aqui o entendemos, é a negatividade enquanto de-cadência do intencionar. E se tratamos antes a respeito de uma dimensionalidade axiológica na condição de um bem emergente da própria intencionalidade, é porque o valorar se dá agora no priorizar-o-outro. E valor, evidentemente, está na possibilidade dessa abertura.

Observamos então as duas dimensionalidades fenomenológicas da vontade que orientam conhecer o Outro que nos vem-de-encontro. Uma trata do querer originário, cujo intencionar enquanto ato de consciência revela o existir das coisas mesmas e a possibilidade de haver nelas algo de não visto. A outra, de sua vez, trata de nosso dirigir-se-a na condição de vontade como preenchimento de um fiat criador. Em ambas, nota-se a condição de possibilidade do encontrar-se a partir de situações especificamente comunicacionais que nos constituem existenciariamente. A consciência de estar ciente da própria figura do Outro - que se vê também cônscio de que em nós há algo de singular e próximo - faz operar em nós o status sentiendi da vontade de dis-por. Mas é importante perceber que o sentir do querer originário não é necessariamente uma espécie de insuficiência em relação ao estar-em que institui o comunicar. Pois ainda que não baste a vontade para que nos movamos ao afeto em relação a outrem, quando intencionamos o Outro à emergência do presentar-se de seu Rosto, é sinal de que nos orientamos pelo dis-positivo de satisfação do mais essente do querer primeiro.

\footnotetext{
${ }^{45} \mathrm{E}$, portanto, sequenciarmos à própria circularidade dos sentidos pelo comunicar, que agora penetram o cerne do vivido cultural.

${ }^{46}$ HEGEL, 2002.
} 
Se passamos ao largo, como reforçamos há pouco, é tão somente porque nosso querer originário não se deixou capturar por quaisquer motivações em relação ao encontro. Ou, noutros termos, quando o ser não se entrega à crença de que algo na relação emergirá a ponto de se deixar construir algum sentido. Isso não seria, a princípio, o mais aparente do desprezara-outrem? Não exatamente. O desprezo se apresenta apenas na emergência mesma do querer negativo. Como não tratamos disso até aqui, resta considerar então que, querendo, o ser deixa-se capturar por possibilidades outras ao relacionar. Percebam assim que a ineficácia do encontrar-se não é o mesmo que uma impossibilidade sua em operar. Contornar a relaçãocom-outrem é também des-velar a impraticabilidade por ausência de alguma motivação que oriente o dis-por. Do contrário, comunicar seria sempre o mais aparente do estar-jádeterminado.

Se o querer que nos funda essencialmente humanos pelo des-velar à consciência não é condição primeira ao relacionar, é preciso se ater ao fato de que também não é da vontade mesma que nos fazemos seres-para-o-outro. O atributo essente de que tratamos é uma segunda vontade, i.e., a de atender à primeira pelo encontrar-se do ser que se abre às possibilidades. É preciso então querer saciar o querer originário. Render-se ao fundamento de manter com o Outro o relacionar que estreita mais aquilo que nos torna tão concomitantemente iguais e discrepantes.

Se mantivermos esse mesmo pressuposto em relação às premissas concernentes ao dialogar, vistas no tópico anterior, entendemos que não há necessariamente a obrigatoriedade de uma linguagem em comum para que mantenhamos quaisquer tipos de afetividade paracom-o-outro. Se tratamos a respeito do mais essencial do querer, sobretudo da vontade de deixar-se ceder a este, basta então o encontrar-se para que do intencionar tenhamos a relação? A este respeito, nos posiciona Rousseau:

\footnotetext{
desde que um homem foi reconhecido por outro como um ser sensível, pensante e semelhante a ele próprio, o desejo ou a necessidade de comunicar-lhe seus sentimentos e pensamentos fizeram-no buscar meios para isso, tais meios só podem provir dos sentidos, pois estes constituem os únicos instrumentos pelos quais um homem pode agir sobre outro, aí está, pois, a instituição dos sinais sensíveis para exprimir o pensamento. (ROUSSEAU, 1978, p. 159).
}

Aos homens incorre, por sua vez, que também os sentidos, os sentimentos e o próprio querer de dar a eles substância junto ao outro, são parte do dis-positivo que configura nossas ações comunicativas a partir do intencionar. Mas percebam que, à ausência do partilhar de um 
sistema simbólico codificado consensualmente a partir do in-comunicar, não teríamos condições de orientação ao con-viver pacífico. É preciso então observarmos como o preenchimento do querer originário institui as articulações necessárias à relação humana na instância de um estar-em socialidade. Noutros termos, perceber em que medida da vontade de atender a vontade primeira, configuramos as instâncias donde emergem as possibilidades de nosso relacionar, sejam linguisticamente estruturadas ou movidas por sentidos que sustentam algum tipo de entendimento.

Vimos, até aqui, que essa transição do intencionar à relação pontua, na realidade, outra de importância fundamental, qual seja, a da barbárie ao estado de civilidade que nos fundou na condição de sujeitos. Essa ideia é cara àquilo que mais adiante entenderemos como o princípio da socialidade pelo intencionar do especificamente essente ao fenômeno comunicacional e também enquanto emergência à atividade jornalística. Mas por hora, mantenhamos a problematização deste tópico. Se Rousseau acreditava que a paixão nos fez migrar de um estado de constante conflito ${ }^{47}$ a um entendimento que se mostrou pelo desejo de conhecer o Outro, temos no dis-positivo o marco que celebra essa passagem.

A noção de positividade, enquanto chave conceitual à compreensão desse tipo singular de articulação se apresenta como elemento histórico a conter em si as normas e procedimentos que mais tarde se transformarão em instituições, tomando rumos outros à medida que evoluem os modos pelos quais se configuram o viver social diante do próprio estar-emcomunicação. Embora não tratemos especificamente do conjunto de regras ${ }^{48}$ a que consensualizamos a partir do mais essente à abertura do in-comunicar, é a ideia de sujeito que apropriamos aqui para orientar as premissas que fundaram as formações em torno de um princípio mesmo de socialidade para, somente então, observar os contextos que fizeram do jornalismo a esfera de ordenação informativa com a qual hoje lidamos.

Em primeiro lugar, na condição de ser-que-se-põe-a-relacionar pelo querer intencional, experimentamos as próprias vivências enquanto repertórios para-nós, embora o abrir-se do ser seja menos questão de aprendizagem do que de ver-se em livre-arbítrio à clareira inicial pelo comunicar. Disto, criamos estruturas específicas a ponto de fazer com que a emergência mesma do relacionar não se oriente pela indiferença ou belicosidade

\footnotetext{
${ }^{47}$ Por acreditarmos que não haveria no Outro um ponto de semelhança que a princípio nos unisse.

${ }^{48}$ Apesar de nos situarmos em relação a uma perspectiva existencial e humanística quanto ao fenômeno comunicacional, não deixaremos de pontuar alguns aspectos concernentes à sua dimensionalidade normativa, embora nada tendo esta que ver com a constituição mesma de regras ao comunicar, e sim às singularidades existenciárias da própria relação.
} 
mútuas. O dis-positivo opera então no sentido de reconciliar essa natureza espiritual de servivente com o aspecto mais histórico concernente à construção de saberes, institucionalizando as regras que conservarão a pacificidade de um viver possível. Essa premissa não direciona à contramão do tipo de ontologia fenomenológica que até aqui se propôs? Não necessariamente. Se acaso quisermos nos aproximar das singularidades da episteme jornalística e seu modo de operação, é preciso antes compreender o início do estar-em-socialidade a ponto de enxergar a partir de que princípio operativo se deu a emergência sua enquanto atividade. De todo modo, se o que buscamos é o eidos do fenômeno comunicacional à operação do jornalismo, a proposta maior deste trabalho permanece inalterada. Pois nos humanizamos, então, pela operacionalização do encontar-se que institui as mudanças do limiar da animosidade por não conhecer ainda quem é para nós esse Outro e o con-viver apoiado às condutas que garantirão um estado pacífico.

A noção de dispositio encerra em si uma dimensionalidade diferente em relação ao que até então pressupomos. Já não se trata do dis-por enquanto abrir-se às possibilidades a partir de um fiat criador, mas, na própria instituição do ser visto na condição de sujeito, aquilo que se dirige ao fazer-se-capturar. Sendo assim, sua operação específica concerne ao modo de construção do permanecer-em-si responsável como forma de gerência do coletivo. Se tratamos da transição da barbárie à civilidade, foi necessário que o sujeito emergisse como um limiar, orientando os homens à não de-cadência do querer originário.

A a positividade se constrói agora em função do formar-sujeito. Isso não nega o pressuposto aceito até então a respeito de um sair-de-si como orientação ao Outro? Não necessariamente. Em primeiro lugar, as normas consensualizadas a ponto de formar as primeiras articulações em torno de uma socialidade foram resultado da emergência do dis-por inicial do ser. Segundo porque, o sujeito constituído agora na condição de ser-capturado, permite-se sair-de-si como direcionamento ao con-viver na conjuntura, i.e., pela visão de conjunto implicada no estar-em-socialidade.

Há então que se questionar: se há certa urgência quanto à pacificação de entes ainda não tidos por sujeitos, não estariam os dis-positivos impondo limites estratégicos ao próprio viver e, portanto, à relação de mutualidade que criamos junto ao próximo? Para tanto, consideremos essa ontologia das criaturas de que até então tratamos, i.e., nossa condição primeira de seres-para-o-relacionar, na qual não havíamos ainda descoberto - ou ao menos não tivesse daí emergido a urgência para tal - a vontade de con-viver a ponto de criar laços 
intersubjetivos de afetividade com o alheio. Vivíamos, por isso, voltados ao conflito e à estranheza de não nos reconhecer nesse não-eu. Despertamos a consciência de que havia neste uma proximidade que nos separava pela ausência intencional da vontade de atender ao querer de estar-com-e-para.

Indo então de-encontro- $a$ e constatando a possibilidade de um relacionar orientado ao bem, percebemos que teríamos de sofisticar o telos do in-comunicar no sentido de impedir a de-cadência mesma de estados outros de barbárie e negatividade a operar no mais aparente do não-solidário enquanto precedência. Pusemos assim em operação os primeiros dis-positivos que configuraram o modus vivendi deste ser aberto que agora é sujeito pelo deixar-secapturar.

Uma terceira instância surgiu desse deixar-se-capturar no mais essente do ser, se interpondo como aquilo que supera o status de conflito perpétuo. Nos tornamos, portanto, seres que não apenas passaram a construir formas singulares de subjetividade, como também as fizemos circular à temporalidade ${ }^{49}$ dos primeiros agrupamentos condicionados pelo relacionar, criando saberes e normas a servirem de conduta a partir do sair-de-si enquanto orientação ao estar-para-o-outro numa circunstância situacional coletivizada. Cultivamos então a permanência desta nova condição, pelo encontrar-se a ponto de engendrar camadas valorativas e mesmo morais que nos guiaram à civilidade a partir de consensos e convenções pelo tensionar e estar-em-solidariedade, preenchendo o querer originário que nos moveu ao mais emergente do relacionar-com.

É desse deixar-se-capturar, portanto, que tratamos aqui a ideia de dis-positivo enquanto princípio operativo ao estar-em-relação da condição humana, ou ao menos do querer preencher o querer originário de pôr-se-a-relacionar no encontrar-se do ser que se permitiu abrir-se às possibilidades do fiat $t^{50}$ ao próprio comunicar. Nos permitimos à captura a ponto de criarmos toda uma articulação - agrupamentos, comunidades, linguagens - que atendesse ao querer de viver junto-ao-outro. Pois preferimos, por assim dizer, os grilhões da relação a ter de encarar o conflito perpétuo e a solidão. Somente assim engendramos as condições necessárias e adequadas à transição entre guerra e pacificação enquanto já sujeitos,

\footnotetext{
49 Temporalidade tida aqui nos termos de um estar-ao-âmago do mais histórico enquanto tradição cultivada pelo incomunicar.

${ }^{50}$ Este fiat criador é aqui entendido nos termos de um que-assim-seja enquanto princípio configurativo do comunicar, i.e., como aquilo que há de mais prático do pôr-se-a do relacionar.
} 
desenvolvendo mais e mais as instituições que mesmo hoje garantem nossas relações e impedem, até certa medida, que hajamos para e pela carnificina.

Se removermos o sujeito enquanto emergência do encontrar-se, regressaríamos ao estado primeiro de não-dis-posição como o mais essencial do permanecer-em-si. Do mesmo modo como, ao eliminarmos as instituições que criamos à finalidade de autogestão, enfraqueceríamos os laços então desenvolvidos ou teríamos de pensar em formas outras a ponto de reforçá-los. Quando da vontade de conhecer o Outro nos orientamos ao deixar-secapturar do querer-atender, fizemos mais que simplesmente satisfazer a vontade primeira enquanto ato consciente, porquanto buscávamos, a princípio, um estado de felicidade antes não experimentado como forma de constituição do próprio existir. Enxergamos no Outro a possibilidade de nos vermos humanamente felizes pelo dis-por no encontrar-se da semelhança.

Ponderemos brevemente: se nos permitimos à captura do dis-por a ponto de engendrar as condições do relacionar com-e-para, a incorporação da estrutura sistêmica aqui compreendida como jornalismo não estaria institucionalizando sentidos já postos em circulação? O que o jornalismo então opera é uma expansão de um saber antecipadamente formulado por sujeitos que nada têm que ver com sua estrutura mesma? Como não tratamos aqui da noção de dis-positivo em consonância com a de aparato técnico, mas na condição de deixar-se-capturar que opera sentidos e nos move ao mais essente do relacionar, o jornalismo é tido como instância singular donde se formam possibilidades outras ao enunciar-a-respeitode.

Tomemos por princípio a ideia de que o resultado da atividade jornalística, i.e., os produtos específicos que também operam na condição de dispositivos ${ }^{51}$, têm por função preparar um sentido ainda não instituído pelo encontrar-se do ser dos entes e que não aparece quando da formulação primeira a que chegamos no vivido. Noutros termos, quando criamos sentidos pelo relacionar-com-e-para que mantemos com o Outro, também produzimos uma compreensibilidade mútua que é sustentada pelo estar-em pressuposto no comunicar. Por outro lado, não esgotamos as possibilidades de extensão dos sentidos postos em circularidade, apesar de criarmos os fundamentos de uma con-juntura enquanto socialidade. Somos então

\footnotetext{
${ }^{51}$ Sejam estes jornais, revistas, livros ou quaisquer outros de natureza equivalente.
} 
convidados a fazer construções sobre outras já realizadas, numa espécie de continuidade semântica que em nós rebate até o ponto de também formar subjetividades outras.

O sentido nos constitui na condição de seres de vontade enquanto telos orientado pelo querer do estar-em-relação. Neste ponto, apesar de não termos ainda entrado no escopo da discussão concernente aos modos de singularidade operativa do jornalismo, é possível enxergá-lo já como sendo este invólucro que nos captura ao querer da compreensão ${ }^{52}$ e à vontade de intencionar pelo encontrar-se do que antes também se orientou como tal. $\mathrm{O}$ próprio exercício jornalístico, como possibilidade de sustentação do que é compreensível, também deixa-se-capturar pelo nosso relacionar a ponto de estar-em-circularidade como construção de sentidos outros. Do contrário, seu exercício não haveria de se justificar tão somente enquanto institucionalização arbitrária de ordenação do vivido.

Deste modo nos emancipamos ${ }^{53}$ na condição de sujeitos. Estamos cônscios de nosso agir e institucionalizamos saberes à emergência do dis-por que nos institui existenciariamente. Mas será que o dis-positivo pelo qual opera a atividade jornalística em sua tentativa de ordenar o vivido pela pretensão comunicativa não engendra, contraditoriamente, um afastarse acerca deste? Estaria no próprio controlar a razão da perda de um sentido mesmo que é instrumental e, portanto, desprovido de projeto? Não racionalizamos o viver para dominarmos a con-juntura a que chegamos pelo relacionar. É preciso então fazer o seguinte questionamento: a razão de ser e estar do jornalismo na forma como hoje se configuram nossas sociedades não marca o fim da racionalidade a que chegamos pelo comunicar, que tem em si o entendimento e a solidariedade como primados? Seria a atividade jornalística, portanto, a celebração do fim da vontade de atendimento ao querer estar-com-e-para o Outro?

Passemos então à discussão concernente às formações sociais e, em seguida, ao modo como fizemos surgir uma prática necessária de ordenamento dos sentidos circulados a partir do relacionar que se apresenta como intencionalidade informativa. O que nos capturou, se, de início, não havia ainda uma estrutura como a do jornalismo? É a respeito das condições adequadas a tal emergência de que trata o próximo capítulo deste trabalho, que também levantará as bases conceituais acerca de uma configuração comunicacional operando em sua articulação epistemológica.

\footnotetext{
${ }^{52} \mathrm{E}$, portanto, da sustentação enquanto sentido mesmo.

${ }^{53}$ Emancipação entendida aqui enquanto sair-de-si pela orientação mesma de um construir-sentido.
} 


\section{DAS FORMAÇÕES SOCIAIS PELO IN-COMUNICAR (OU DA UNIDADE COMO PRINCÍPIO DO ESTAR-EM-SOCIALIDADE)}

Vimos que a estruturação das línguas se tornou resultado imediato do querer originário no qual, pelo intencionar, nos movemos à vontade de estar-com-e-para à emergência de toda inquietude e desolação. Do mesmo modo como, pelo presentar-se ôntico do Outro a partir dos aspectos seus enquanto alheio, a intencionalidade se apresenta como vontade de atender ao querer fundante, numa espécie de captura do ver-se-em-jogo que nos direciona à ação. Desse dis-positivo, portanto, demos início à configuração de um estar-emsocialidade pelo mais essente do in-comunicar.

Os sentidos postos-em-circulação numa ambiência agora tida por societária, sequenciam atos comunicativos a ponto de a mutualidade do relacionar compor a lógica operativa à formação do viver-em-comunidade. Noutros termos, configura-se a reciprocidade entre o $\mathrm{E} u$ que é essencialmente comunicativo e o Nós alcançado somente numa instância que também é comunicacional. Se, por um lado, do querer originário fizemos emergir uma relação nos termos do mais essente do fenômeno comunicacional, por outro, foi a partir das estruturas criadas a ponto de se ampliar e regular o próprio estar-em-socialidade que nos conduziu às primeiras articulações de um viver à con-juntura. Fizemos então operar os dispositivos enquanto telos que é sempre Bem em seu se-mostrante e à vontade mesma de comungar sentidos.

Somos compelidos então a perceber que o início de uma in-socialidade se mostra possível quando nós, já na condição de sujeitos que deixaram a barbárie pelo encontrar-se do querer fundante, confrontamos situações de um pôr-se-a-relacionar que se volta ao existir coletivo pelo estar-em da comunicação. Trata-se, ao fim, de tensionamentos ou excitações que envolvem - e, portanto, capturam - à orientação pelo bem comunalizado do querer-continuar com o Outro a ação comunicativa que nos institui sujeitos no-mundo. Mas esta, de sua vez, deve partir do arbítrio fundante de um querer-estar-junto.

É preciso que o dis-positivo da vontade de atender a vontade primeira de direcionarse-para-o-outro opere no sentido de engendrar as condições possíveis de nosso relacionar. Mas há aí, entretanto, algo que extrapola o querer e que também é condição sine qua non à 
estruturação de um estar-em-socialidade, qual seja, o interesse. Vimos antes ${ }^{54}$ que Rousseau trata de um bem comum na condição de finalidade de uma formação social. Somente a vontade geral em torno de algo intencionado pode organizar os conflitos de interesses particulares numa articulação que se dá pelo agrupar-se. Noutros termos, o que "existe de comum nesses vários interesses forma o liame social e, se não houvesse um ponto em que todos os interesses concordassem, nenhuma sociedade poderia existir" ${ }^{55}$. É, portanto, um compromissar-se - para usar o vocabulário rousseauneano -, embora interesse é tido aqui menos como um agir estratégico do que um fim último orientado ao viver-à-con-juntura.

O que configurou os primeiros agrupamentos pelo estar-em pressuposto na noção de socialidade, não foi resultado de operações originadas pela negatividade característica do nãorelacional, i.e., nada tiveram que ver com a anterioridade ${ }^{56}$ do próprio in-comunicar. No estado de seres viventes, nos deparamos com obstáculos que sobrepujaram as forças de que dis-pomos para nele nos mantermos ${ }^{57}$, e que, em maior ou menor grau, tratam da ausência do encontrar-se a partir do fazer-história. Assim, do dis-por enquanto preencher do intencionar, passamos agora ao contrato que moraliza o que não tínhamos antes do estar-à-con-juntura.

Antes de intencionarmos o mundo, nossas ações conscientes se orientavam pela sobrevivência e à perpetuação da espécie. Mas o que fazíamos quando não realizávamos nenhuma destas atividades? Tentávamos, afinal, compreender o ambiente em que vivíamos. Despertamos assim a vontade teleológica que futuramente nos conduziu à urgência de pôr-seem-relação com o Outro. Percebemos em algum momento que se estivéssemos em con-junto com este, teríamos condições necessárias à continuidade do agir de sobreviver e procriar. Do querer fundante à emergência do intencionar, configuramos a necessidade do comum pelo telos da con-vivência. Os termos de nosso contrato, a princípio, tinham por finalidade a orientação à sobrevivência, e, não propriamente, relação ou garantia de um direito comum. Mas operamos, no entanto, o início de uma comunicação em nós já instituída. Se chegamos a um acordo - seja este de orientação estratégica ou à solidariedade pelo Bem -, foi tão somente pelo fato de que despertamos o querer do in-comunicar. E do contrato, também tomado por

\footnotetext{
${ }^{54}$ Cf. p. 36, § 2 e segs.

${ }^{55}$ Cf. ROUSSEAU, Jean Jacques. Do contrato social: Ensaio sobre a origem das linguas; Discurso sobre a origem e os fundamentos da desigualdade entre os homens; Discurso sobre as ciencias e as artes - 2. ed., Sao Paulo: Abril Cultural, 1978, p. 43.

${ }^{56}$ Anterioridade vista aqui enquanto estado que antecede o pôr-se-a-comunicar e não, propriamente, uma precedência ao fenômeno.

${ }^{57}$ Cf. Id., ibid., p. 31.
} 
um tipo específico de dis-positivo surgido da urgência, aprendemos a voltar nossas ações comunicativas no intento de mantê-lo e dar sentido à sua operação.

A noção de contrato, portanto, razão alguma teria se removêssemos de seus atributos o princípio do querer-estar-em-relação. Por isso, enquanto tal, não basta a si mesmo, já que é necessária uma constante regulamentação pelo comunicar até o ponto de fundar as condições de sua manutenção. Fica então o questionamento: se o contrato nos garantiu a civilidade operada comunicacionalmente e nos guiou então ao bem comunalizado, não havia então convenção alguma no estado de natureza? Tratamos já acerca de duas necessidades que garantiram mesmo depois o estabelecimento de um contrato entre nós: sobrevivência e procriação. Nesse sentido, tínhamos tão somente um tipo outro de urgência, que não se apoiava ao telos nos termos como aqui o entedemos. Ora, se versamos a respeito de uma essência que nos funda e pela qual constituímos nosso existir pela orientação teleológica do querer estar-para-outrem, não é pela convenção que chegamos ao contrato, mas a partir da vontade de querer movimentar o que então asseguraria o Bem comum. Noutros termos, sabíamos que havia um modo de nos tornarmos con-viventes pelo intencionar. Apenas não havíamos ainda sido capturados pelo dispositivo que movimenta o querer corresponder ao querer originário.

O operar do contrato não deve ser encarado tão só enquanto resultado, mas complemento do agir a que chegamos pelo in-comunicar, no sentido até de operarem juntos a ponto de assegurarem a transição de um $\operatorname{limiar}^{58}$ a outro. A operação do contrato pelo comunicar remete, sobretudo, a outra não menos pertinente: a de unidade enquanto princípio de validade do pôr-se-a-contratuar. A premissa aqui é a de que, para que se mantenha o contrato, é necessário auxílio mútuo no sentido de sequenciar as operações nas quais este se baseou, que, neste caso, trata-se do relacionar cujo telos se apresenta nos termos de uma pacificação do agir humano.

Em nossas relações intencionadas, tivemos de negociar os sentidos que nos dirigiram a esse estado de positividade enquanto sair-de-si. E disto, compomos um agrupamento maior, centrado nas lógicas das convensões:

desde o momento em que essa multidão se encontra assim reunida em um corpo, não se pode ofender um dos membros sem atacar o corpo, nem, ainda menos, ofender o corpo sem que os membros se ressintam. Eis como o dever e o interesse obrigam igualmente as duas partes contratantes a se auxiliarem mutuamente, e os mesmos

\footnotetext{
${ }^{58}$ Retomando aqui, portanto, a noção de limiar como lugar de passagem, e, não propriamente o que separa
} 
homens devem procurar reunir, nessa dupla relação, todas as vantagens que dela provêm. (ROUSSEAU, 1978, p. 35).

Estabelecemos, pois, os fundamentos de um relacionar enquanto condição de possibilidade, cujo agir se orienta à manutenção contratual na emergência mesma da sustentação da compreensibilidade pelo sentido. Disto, chegamos ao estado de unidade de comunhão no mais aparente do estar-em-socialidade. Agora, se partindo dessa ideia de unidade de comunhão, formamos a estrutura da socialidade, que princípio nos difere doutras espécies de animais que também se organizam em favor de uma atividade comum? Basta observarmos a condição de privilégio quanto ao modo como instituímos nosso viver-à-conjuntura, i.e., o ser do dis-por que se abre às possibilidades do in-comunicar. Para além da premissa de que convencionalizamos regras singulares de conduta, o fazemos antes no que compete ao querer de tornar geral uma vontade a que chegamos consensualmente. Noutros termos, o contrato também garante a convensão de nossa vontade consensualizada, que emerge do negociar das relações. O que nos orienta e difere, portanto, de quaisquer outras espécies, é a ideia mesma de que nessa unidade instituiremos os princípios que guiam ao bem comunalizado.

Da formação da unidade, no entanto, emerge outra de natureza semelhante à contratual, cujo fim último se volta à responsabilidade de asseguramento da vontade à figura de um só. Há uma diferença, portanto, entre convencionalizar a vontade de um único sujeito e transferir a este o escopo das nossas. Para que a relação que se dá nos termos deste negociar não se torne o prelúdio de uma dominação de um sobre todos, é preciso um princípio que também consensualize essa transferência, qual seja, o de legitimidade. Assim se garante também a sensação de que o único regerá a vontade geral de modo a respeitar a não distinção dos sujeitos em razão da unidade. Por isso é fundamental um crer-em nos termos de uma legitimidade, que se dirija ao con-junto de nossas vontades e garanta a continuidade do relacionar-com-e-para. Mas há que se questionar: não se trata, ao fim, de uma sujeição estratégica? Acaso também não foi assim que estruturamos as condições ao surgimento de uma atividade como a do jornalismo, no sentido de ordenar o que a princípio não éramos sozinhos capazes?

Em primeiro lugar, é preciso observar a característica fenomêmica do próprio pôr-sea-contratuar, i.e., compreender que também ele é resultado emergente do estar-em- 
socialidade como forma de orientação ao Bem. Negociamos os sentidos de nossas crenças e vontades e concordamos de antemão com o que virá à seguir, como se abríssemos ao ser a temporalidade de um por-vir. Do mesmo modo como, na condição de fenômeno, damos continuidade ao próprio negociar até o ponto de convencionalizar sentidos outros que se somam àqueles então abandonados. Só há a troca, a negociação e, de igual importância, a reformulação, por sermos livres à lógica do contratuar. Por esse motivo tratou Rousseau acerca de um rompimento, porquanto não há "nenhuma lei fundamental que não possa ser revogada [...], pois, se todos os cidadãos se reunissem para, de comum acordo, romper esse pacto, não se pode duvidar que fosse muito legitimamente rompido" ${ }^{\text {"59 }}$.

Se devemos considerar o resultado de nossas convenções como sendo um tipo específico de sujeição, sem a operação de um romper-com, teríamos em nosso relacionar tão somente um instrumentum ao estar-em-socialidade. Mas acaso não é o próprio rompimento o princípio operativo de qualquer revolução ou bruscas mudanças estruturais? Se percebemos que as convenções se orientam aos benefícios de um só em vez de uma solidariedade precedente ao próprio agir, rompemos com a con-juntura a que chegamos quando do estabelecimento do contrato primeiro. Pois se lidamos aqui com negociações que operam por tensionamentos e partilhas simbólicas no in-comunicar, exercitamos saberes no sentido de sequenciarmos o mais essencial do pôr-se-em-relação na medida em que comunicamos.

Se chegamos até aqui partindo da premissa de que as convenções que fundamentam o estar-em-socialidade se dão na emergência mesma do in-comunicar, é preciso então observar o modo pelo qual possibilitaram a urgência de um jornalismo cujo exercer de si também se consolidou pelo relacionar-com-e-para. Nesse sentido, em que medida o estar-em pressuposto do comunicar fez surgir uma atividade que buscou inicialmente ampliar os sentidos postos já em circulação? O que funda o jornalismo é também um contrato que nos fez transferir algo a uma entidade ordenadora de nossos sentidos ou resultado de um rompimento pelo pôr-se-a-contratuar? Deste ponto em diante será necessário debruçarmos ao locus donde a atividade jornalística se principiou, i.e., ao seio do que trataremos a seguir como núcleo do estar-em-publicidade. Daí, chegaremos à discussão concernente à circularidade de sentidos no vivido em consonância com o saber-fazer jornalístico.

\footnotetext{
${ }^{59}$ Cf. ROUSSEAU, 1978, p. 114 - Grifo nosso.
} 


\subsection{Da Formação dos Espaços Públicos ao Início da Atividade Jornalística}

Se antes, quando da instituição dos contratos, chegamos a uma forma de ser que, sendo, se vê em-socialidade, por outro lado, também criamos um status hierárquico de configuração que opera os termos do próprio negociar. Em razão disto, moldamos essa espécie de espacialidade universal ${ }^{60}$, que, a longo prazo, fez também despertar em nós o querer de engendramento doutros que operassem novos tipos de tensionamentos. E se, da relação nos pusemos ao mais essencial do in-communis, foi a partir da diferença de interesses entre uma e outra que tentamos recuperar o que o modelo hegemônico de algum modo nos fez perder. Assim surgiu em nós a vontade de estruturar um espaço outro, que fugisse à lógica da estrutura primeira, mas que, também ele, fosse consequência imediata de um viver-conforme.

Com efeito, esse novo espaço se mostrou tanto mais frágil, embora dinâmico se considerados os sentidos a que chegamos pelo in-comunicar e também as informações que fizemos circular sem pretensão alguma de operar a relação. De um lado, o querer-romper como modo de instituição nossa no-mundo. Doutro, a estruturação formal a partir de normas específicas de uma ambiência ${ }^{61}$ orientada ao debate do que ocorria noutras instâncias. Nasce assim o que aqui entendemos como núcleo do estar-em-publicidade, i.e., uma esfera social donde o tornar-visível de nossos saberes se fez menos como estratégia do que, propriamente, condição de urgência de preenchimento à vontade mesma de construir sentidos outros.

Há um detalhe que carece de atenção: no instante em que atendemos à vontade de atribuir a outrem a responsabilidade de reger nossos saberes e governar sobre nosso vivido, enfraquecemos o laço de proximidade solidária que, antes, no estado ainda de não-civilidade, tentamos reforçar ao presentar-se do Outro. Disto, chegamos a um estado de con-vivência que articula pontos de isolamento em relação àqueles que se afastam do núcleo operativo de nosso co-mungar. Mas se antes os agrupamentos humanos mantinham isolamentos entre si, o que mudou quando da organização em torno do estar-em-socialidade? Alterou-se a noção de estratégia. Se o isolamento nos era imposto pelas condições do ambiente ou pela não sapiência de haver outros que viviam como nós, passamos a instituir espaços relacionais no sentido de reforçar vínculos com aqueles que se tornavam mais próximos se comparados aos

\footnotetext{
${ }^{60}$ Cf. WOLTON, Dominique. Pensar a comunicação. Brasília: Editora Universidade de Braília, 2004.

${ }^{61}$ Utilizamos aqui o termo ambiência no sentido de reforçar sua característica enquanto modus vivendi pelo instituir ontológico do ser, e não meramente de lugaridade física.
} 
demais. O princípio do relacionar-com-e-para passou a operar pela estratégia de um novo tipo de sobrevivência, i.e., transações comerciais ou tentativas de união territorial.

O viver civilizado não pontuou o fim da barbárie ou da negatividade do ser. Apenas migramos do desconhecimento à estratégia de um estar-consciente-de pelo querer-a, em que a vontade mesma de romper-com nos orientou a tipos outros de agir. Uma vez engendrada a estrutura a que chegamos, o conjunto de nossas relações passou a ser não mais numeroso e menos contraditório, posto que não se tratou mais do estar-junto a fim de conhecer o Outro, mas de conseguir deste aquilo que nos fosse de serventia. O estar-em-socialidade, nesses termos, celebra então o fim do in-comunicar a partir das afetidades da relação do ser dos entes em extensão? Evidentemente que não.

Como não havia mais o total desconhecimento do Outro que se nos apresentava à emergência do ser pelo deixar-se-intencionar, passamos então a querer reforçar o vínculo com os que estavam familiarizados às normas já convencionalizadas. Por certo não eliminamos as hostilidades ou a noção da estranheza, muito embora o ser de nossa instituição mesma tenha se constituído pelo sair-de-si enquanto orientação à não de-cadência. Estávamos já aptos a nos organizar em-socialidade e manter vínculos a ponto de privilegiar uma convivência que também nos fundou existenciariamente.

Passamos então a digirir todas as diferenças pontuais que, a princípio, ruíam a pretensão de unidade que criamos. Se fizemos operar a vontade de independência frente aos desígnios de um só a quem elegemos consensualmente pelo princípio de legitimidade, também criamos um locus que operasse a circulação de um sentido bastante singular, qual seja, a emergência de nosso opinar. Não buscávamos mais a representação de alguém que nos regesse, mas tão somente o presentar-se do que se formava a partir dos tensionamentos dóxicos no vivido.

O princípio operativo à lógica disto a que entendemos por núcleo do estar-empublicidade era o da auto-nomia. Ver-se não necessariamente livre do que era até então circulado, mas cônscio de ter ao ser a razão prática no ato de opinar enquanto fundamento para o pensar crítico ${ }^{62}$ a respeito da con-juntura do ver-se-em-civilidade. Pusemos assim em articulação o resultado do que antes racionalizamos até o ponto de romper-com - ou

\footnotetext{
${ }^{62}$ Por crítica, entendemos aqui a singularidade pensante do ser que, no abrir-se às possibilidades, vê-se em condições de avaliar as potencialidades e limitações de si e do mundo circundante.
} 
sugerindo-o como possibilidade - em relação aos tipos de saber tornados hegemônicos a partir do pôr-se-a-contratuar.

Se transferimos a responsabilidade à figura de um só, que teria de nos guiar a um estado de justiça e harmonia ${ }^{63}$, agora, por sua vez, sentimos que a situação tomou novas proporções no sentido de despertar em nós o querer que encerra em si a possibilidade de rompimento.

Do querer enquanto ter-para-si-a-auto-nomia, o abrir-se do ser que em nós é de mais essente permitiu-se capturar à mudança pelo romper-com e à circularidade de sentidos pelo dóxico. Desse modo, do espaço em que publicizamos a opinião dissociada do saber hegemônico, fizemos também emergir o início de uma atividade reguladora de nosso opinara-respeito-de, até o ponto de levá-lo à luz de lugaridades outras. Nascia dessa urgência o embrião do fazer-jornalístico. Sua função enquanto tal nada é senão que uma criação moderna e resultado quase imediato do esclarecer próprio ao Iluminismo. Sua essência, por outro lado, precede a Modernidade e a necessidade que se fez emergir dos espaços de publicização do opinar. Antes da própria necessidade ao ser na medida em que nos deixamos capturar à emergência do querer-romper-com, havíamos já criado as condições necessárias para que, dos sentidos construídos e circulados, surgisse também a vontade de ter-ciência-acerca-de.

A atividade jornalística, portanto, não nasce na condição de saber nunca antes operado, mas tão somente como preenchimento duma vontade que em nós era primeva, qual seja, a de fazer circular comunicacionalmente o conjunto de sentidos dóxicos pela racionalização. Este saber-fazer nada tem que ver com uma urgência ao mais essente do ser, mas disto, revela a emergência de se estruturar o já estruturado pelo aberto existenciário. Por exemplo, quando instituímos nosso existir a partir do comunicar orientado pela precedência do amor e da responsabilidade, nos pomos à configuração do estar-em-socialidade. Percebam então que a razão constituinte do jornalismo enquanto atividade mesma é epistemológica no sentido de que seu verdadeiro emergente já nada tem que ver com a clareira fundante, mas com as possibilidades do que se vê então aberto, ainda que se fundamente pelo relacionar.

Pode-se então questionar se dessa configuração passamos à urgência de se institucionalizar uma atividade que a princípio surgiu do querer-relacionar-com. $\mathrm{O}$ fato de termos criado uma estrutura aos moldes duma burocratização estatal que também ela opera

\footnotetext{
${ }^{63} \mathrm{E}$, portanto, ao mais essente do Agathon (Bem) pelo des-velar das coisas mesmas.
} 
por legitimidades, não conduziu à separação nossa enquanto sujeitos a ponto de não buscarmos mais uma relação que se orienta pela compreensão do Outro e tem por primado a solidariedade? Por hora, centremos a continuidade da análise no modo como esses espaços em que passamos a publicizar sentidos guiaram à urgência de uma estruturação jornalística aos moldes como hoje a conhecemos.

Partindo do que até aqui foi exposto, não foram os espaços em si que, de algum modo, estenderam o agir-pelo-comunicar a instâncias outras, mas estas é que fizeram emergir a possibilidade de se apresentarem de modo inabitual. Pelo in-comunicar operamos o querer de fazer disto o telos de um estar-para. E desses espaços de publicização do que se discutia, nasceu ainda outro tipo de urgência, qual seja, a de reificar o discutido numa linguagem outra que não a fala, mas que, ela própria, carregasse em si a potência discursiva do que então já fazíamos. Criou-se uma espécie de medear entre o que era enunciado e o alvo primeiro da enunciação, i.e., os sujeitos que passaram então a assumir a postura de público.

Dessa urgência de materialização do temático posto em discussão, tivemos de pensar no potencial de alcance a que chegaria o resultado do que se discutia, que não era, a princípio, $\mathrm{o}$ mero ato de se ater ao que ocorria na lugaridade primeira. O objetivo era fazer operar o querer mesmo de racionalizar, problematizar a con-juntura e chegar à vontade de romper-com a partir do esclarecimento pelo comunicar. Por isso não bastou que um único sujeito se pusesse em consonância ao que se discutia nesses espaços e, disto, levasse o resultado do que era pontuado a outros em que também tomava parte. A urgência a qual aqui tratamos nos guia ao medium, essa espécie de limiar que permitiu não apenas a reificação dos temas e propostas, mas garantiu a sequencialidade do discorrer-acerca-de.

Se a ideia era fazer com que os assuntos problematizados não fenecessem quando do alcance a espaços outros, foi preciso então que algum meio os sequenciasse a ponto não de assegurar-lhes a validade existencial, mas a certeza de que moveriam sujeitos a pensar em possíveis resoluções e saídas aos conflitos de uma época. Por isso se mostrou insuficiente o atrevimento daqueles que se prestavam a esse trans-portar do discutido entre espacialidades diferentes $^{64}$, muito embora tenha sido disso que fizemos surgir a urgência. Foi necessário, pois, a criação de um meio específico a ponto de fazer germinar a atividade de uma imprensa quase aos moldes como hoje a conhecemos.

\footnotetext{
${ }^{64}$ Cf. KOVACH, Bill; ROSENSTIEL, Tom. Os elementos do jornalismo: o que os jornalistas devem saber e o público exigir. - 2. ed. - São Paulo: Geração Editorial, 2004, p. 37.
} 
Tomemos a seguinte questão por premissa: essa atividade de dar seguimento às discussões nos espaços públicos substituiu o ato mesmo de se discutir-acerca-de. Do mesmo modo como não bastou estendê-las de canto a canto dos espaços públicos, pois foi também insuficiente a ação de alterar a construção comunalizada a ponto de orientar às propostas iluministas ${ }^{65}$. Tivemos de, uma vez mais, delegar a responsabilidade à figura de um só, que lidimasse o exercício e o compromisso de fazer emergir dos sujeitos a vontade primeira que a princípio era essência da condição de estar-em-publicidade, i.e., o querer discutir movente à vontade mesma de romper-com. Dessa legitimidade e urgência, profissionalizou-se o exercício que assegurava a perpetualidade da essência aqui considerada. Criamos, da necessidade e da singularidade das circunstâncias, a razão de ser e estar de uma nova condição: a de jornalista.

Aos poucos, a atividade de assegurar a continuidade do que se discutia cedeu passagem à necessidade de criar um conjunto de normas que legitimasse o saber-fazer jornalístico que tomava forma. Do resultado imediato de sua formulação ${ }^{66}$, pusemos em operação os produtos que encerravam em si a ideia formal do ato mesmo de discutir-sobre, que, neste caso, presentava-se às páginas do próprio papel a servir de matéria aos jornais. Em si, não era este o produto de que aqui se trata, porquanto fazia as vezes de dispositivo que preparava aos sentidos ${ }^{67}$ e garantia uma continuidade enunciativa. Trata-se então do modo como eram organizados os assuntos pelo pôr-se-a-medear, i.e., de como hierarquizar aquilo que se discutia nos espaços públicos no sentido de engendrar um todo significativo àqueles agora tomados na condição de público. A esses produtos, inicialmente tidos em forma de críticas literárias e artísticas, atribuiu-se a característica que hoje comumente se costuma chamar de notícia.

Mas o que assegurou a criação das deontologias que serviram de princípio ao exercício? A mera transferência de responsabilidade à figura de um profissional que emergia desse cenário não foi condição primeira ao desenvolvimento da atividade. Foi preciso, de início, especializar a ação mesma que em si a lidimava. Noutros termos, não se tratou unicamente do fazer, mas do que este operava e que diferia da atividade dos demais sujeitos

\footnotetext{
${ }^{65}$ Cf. RODRIGUES, Adriano Duarte. Estratégias da comunicação: questão comunicacional e formas de sociabilidade. Editorial Presença, 2. ed., Lisboa, 1997, p. 41.

${ }^{66}$ Que se orientava por princípios e valores a ponto de engendrar uma deontologia própria e singular à atividade então nascente.

${ }^{67}$ Para análise mais aprofundada, ver MOUILLAUD, Maurice; PORTO, S. Dayreall (Org.). O jornal: da forma ao sentido. 2. ed. - Brasília: Editora Universidade de Brasília, 2002.
} 
agora tidos por não especializados. Do mesmo modo como também as regras não garantiram o desenvolver do embrião jornalístico, pois era preciso o despertar da vontade de a elas aderir. A lógica operativa do início da atividade do jornalismo guiava à sua institucionalização a partir do próprio conjunto de regras criado, engendrando uma espécie de conhecimento gnóstico em relação aos atos que as sustentavam. Nesse sentido, à formulação do conjunto de regras que orientaram os primeiros profissionais e, concomitantemente, a ideia mesma acerca do que seria um, criaram-se grupos mais ou menos fechados e com ideologias mais ou menos próximas de um exercício que a princípio todo cidadão fazia já de comum acordo.

Se, portanto, nossas discussões articuladas nos espaços públicos não exigia quaisquer tipos de especialização ${ }^{68}$, por que então chegamos à urgência de uma? O que justificou o profissionalizar e em que medida a criação de uma nova classe à emergência desses espaços fez com que, a longo prazo, instrumentalizássemos ações que a princípio se nos foram essência do agir comunicativo? Em primeiro lugar, consideremos o seguinte: se antes os sentidos de nossas discussões dependiam da inteligibilidade mútua do simbólico que compartilhávamos pela linguagem, no início da atividade de imprensa tivemos de guiar a outro meio o que antes fazíamos. Isto, por outro lado, nos fornece premissas para questionar se acaso não iniciamos os processos que solaparam provisoriamente os espaços criados para a discussão e vontade de rompimento.

De início, centremos a atenção à figura do profissional. Antes mesmo de se convencionalizar as regras que faziam operar a própria atividade, o que emergia dos espaços públicos não era ainda o jornalista. Os encarregados de dar continuidade às discussões articuladas nesses espaços foram os literatos. Se o exercício da continuidade enunciativa exigia o aporte da escrita, nada mais lógico que deixar ao encargo de escritores a incumbência de assegurá-lo. Mas dependiam, no entanto, de atividades que se lhe garantiam o próprio exercício, e que, ao fim, eram exteriores à sua própria, no sentido de operarem tão somente quando da realização dessas outras. A bem da verdade, tratava-se menos de dependência do que, propriamente, de intercalações no próprio exercício. Nesse sentido, formas outras ${ }^{69} \mathrm{de}$ especialização passaram a também lidimar a atividade de início duma imprensa; decorrência imediata da necessidade de manuseio do maquinário que dava forma aos primeiros jornais.

\footnotetext{
${ }^{68}$ Pois se mostravam tão somente enquanto resultado mesmo da vontade que nos movia ao querer-produzir e circular sentidos.

${ }^{69}$ A esta altura, já operava a prensa de tipos móveis que possibilitou a emergência da mediação do jornal nas discussões publicamente engendradas.
} 
Já no início da atividade, fez-se notar uma separação daquilo que se discutia nos espaços públicos e o que, de fato, emergia das páginas dos primeiros jornais. Mas até que ponto esse afastar-em-relação-a criou uma dissonância entre o que se discutia nas ruas e o que ganhava espaço às páginas da imprensa? Se se trata não mais de um estar-emdependência, é possível que ao aprender a lógica operativa das discussões públicas, o jornalismo tenha legitimado a própria autonomia? Evidentemente, como se verá mais adiante neste trabalho, o espaço do vivido e o das mediações a partir das quais se configura o jornalismo não são, de modo algum, realidades de todo separadas uma da outra.

Há que se considerar, por outro lado, que a formação de um grupo gnóstico composto por literatos intelectuais que racionalizavam o mundo vivido fez surgir, aos poucos, a possibilidade para que outros também o fizessem. E se o modo singular de configuração desse início de jornalismo guiava ao afastamento dos espaços públicos e à autonomia legítima que assegurava não mais a continuidade das discussões, mas a da própria existência sua enquanto atividade, é quando da criação de um espaço outro que as regras particulares ao exercício foram convencionalizadas. Eis o modo como emerge a ambiência da redação, que foi para a atividade e profissionalização jornalísticas o que foi a esfera pública àqueles que se propuseram, em dado momento, a romper racionalmente com as conjunturas vigentes.

Se a criação desse novo espaço lidimou a operação de novas regras que fugiam à lógica do estar-em-publicidade donde emergiam as discussões, também ele assegurou-se da formação dos que, ad arbitrium, convencionalizavam as deontologias que orientavam sua techné. Mas, por outro lado, a intelectualidade dos escritores não se mostrou como condição essencial à sobrevivência da atividade que a princípio emergiu dos espaços públicos. Como a mediação que operava a circulação de sentidos era antes tida na linguagem enquanto condição mesma ao relacionar, apenas a submissão das temáticas à razão solidária e comunalizada assegurava a vontade de romper-com.

As discussões enquanto resultado mesmo da essencialidade de nossa vontade que movimentava toda inquietação, tornaram-se uma celebração contratual. Não de natureza semelhante àqueles que nos fizeram migrar da condição de seres viventes à de sujeito pelo estar-em-relação, mas ante a imposição à lógica operativa de uma imprensa enquanto mercado em que quaisquer vontades de fuga são então consideradas como forma singular de resistência. As transformações que configuraram o novo exercício que se diferia do que era 
feito nas ambiências públicas fez com que déssemos ao espaço redacional jornalístico a característica que se aproxima desta espécie de arena de tensionamentos.

É preciso então lançar luz a respeito da questão: migramos ${ }^{70}$ da possibilidade de se discutir à luz da razão todo tipo de assunto que despertava em nós aquilo que se nos capturava à vontade de rompimento com a con-juntura. Disto, criamos espaços outros em que se fez operar relações de tipo diferente do que tínhamos antes, orientados ao mercado ascendente e às lógicas do sistema financeiro. A ambiência da redação exigiu toda uma rearticulação de saberes e de poder no sentido de fazer com que mesmo os intelectuais que assumiram a frente se adaptassem aos ditames dessa nova estrutura. Mas acaso esta, a longo prazo, não fez surgir também nova vontade de rompimento naqueles que imiscuíam-se aos espaços públicos que mesmo a atividade jornalística não findou? Mais até: na tentativa de buscarmos o esclarecimento a ponto de romper com os pensamentos dissonantes duma época, não criamos então uma estrutura semelhante àquela que a princípio buscamos distância?

Ora, se o jornalismo é resultado da urgência de se expandir os sentidos articulados nos espaços públicos para que alcançássemos pela racionalidade outros tantos, sua institucionalização não teria nos orientado à vontade de um querer-romper com os princípios que o constituíam? Para tanto, temos de descentrar as atenções daquilo que legitimou o início da atividade, observando então a lógica do que assegurou a continuidade sua mesmo quando do afastamento daquilo que se discutia no vivido. Se bastassem apenas os princípios regentes do mercado, seria tão somente profícuo que eles próprios instruíssem o exercício do saberfazer jornalístico.

Deve haver algum princípio outro que dê suporte às premissas da própria atividade, porquanto o que lhe justificou a urgência nada tinha que ver com a orientação mesma do mercado. Sendo assim, antes de partirmos aos modos singulares pelos quais o jornalismo assegurou sua legitimidade, é preciso lançar luz a este princípio em consonância à noção de técnica. Se, quando da formação de deontologias, fizemos com que o espaço redacional emergisse, foi de igual importância então que o acesso a este se desse de modo diferente do que se fazia nos espaços públicos. Observemos, então, como a técnica jornalística assegurou a legitimidade que deu sentido à continuidade do exercício jornalístico.

\footnotetext{
${ }^{70}$ Do mesmo modo como antes o fizemos quando da celebração do primeiro contrato que nos pôs em relação.
} 


\subsubsection{Da Técnica como Princípio Configurativo do Fazer Jornalístico (ou da não Subexistência do Jornalismo Enquanto Razão Prática à Vida)}

De início, tomemos uma premissa concernente à ideologia tecnicista que hoje comumente se vê operar na estrutura sistêmica do jornalismo: a de que ela própria garante, eo ipso, a normatividade presente nas singularidades de produção dos sentidos no espaço das relações que estabelecemos mutuamente fora do locus que se criou à atividade da imprensa. Esta normatividade é muitas vezes confundida com o normalismo das operações deontológicas encontradas na própria estrutura que sustenta a atividade mesma. Noutros termos, o maquinário que fez surgir as condições apropriadas à imprensa nos obrigou a pensar a respeito de uma técnica da técnica, que nos pusesse não somente à operação destas, como também à criação de saberes que sustentassem a razão de nosso exercício enquanto tal.

Aderimos, portanto, a uma tecnologia que passou a medear o simbólico que então se interpunha entre a ambiência da redação como extensão da discussão pública e o estar-emsocialidade. Desta tecnologia, tirou-se o pressuposto de que tão somente ela daria conta de fazer circular os sentidos pelo pôr-se-a-relacionar, muito embora não dependia de relação alguma entre os sujeitos. Em que medida, então, o conjunto de técnicas passou de modus a ethos do fazer e pensar jornalísticos? Para tanto, tomemos de empréstimo a noção heideggeriana ${ }^{71}$ concernente à essência da técnica, para então chegarmos ao esclarecimento da questão.

Em primeiro lugar, ponhamos em parênteses a concepção corrente de técnica, para, daí, regressarmos ao modo como esta é apropriada no âmago da ideia mesma de jornalismo e que nos permitirá um questionamento acerca de uma essencialidade que lhe é própria. Se partirmos do pressuposto de que é ela um meio e fazer humano singular, esbarraremos com o ponto em que suas dimensões se voltam a uma finalidade do agir enquanto determinação instrumental a partir da estratégia mesma. Cabe então o questionamento: não há nada além de sua essência que esta noção com vistas a um operar por e sobre que nos guia a um objetivo não comunalizado? Para tanto, tomemos de empréstimo a ideia de desabrigamento ${ }^{72}$ enquanto

\footnotetext{
${ }^{71}$ Ver HEIDEGGER, Martin. A questão da técnica. In: Revista Scientiae Studia. - V.5, N.3 - São Paulo: USP, 2007, p. 375-398.

${ }^{72}$ Cf. Id., ibid. Adotou-se, para fins últimos neste trabalho, a edição datada de 2007, que trata daquilo que o autor, em conferência à Escola Superior Técnica de Munique, proferiu.
} 
o des-velar que se dá pela intencionalidade, i.e., um direcionar-se-à-frente ${ }^{73}$ por nós conduzido. A respeito desta concepção estratégica de técnica, atentemos à reflexão:

também a técnica moderna é um meio para fins. Por isso, todo esforço para conduzir o homem a uma correta relação com a técnica é determinado pela concepção instrumental da técnica. Tudo se reduz ao lidar de modo adequado com a técnica enquanto meio. Pretende-se, como se diz, "ter espiritualmente a técnica nas mãos". Pretende-se dominá-la. O querer-dominar se torna tão mais iminente quanto mais a técnica ameaça escapar do domínio dos homens. (HEIDEGGER, 2007, p. 376).

Parece-nos claro, então, que deve haver algo oculto no cerne mesmo que institui a razão teleológica duma técnica dissociada de fins- $a$. Um ponto específico e singular a que possamos dar por essência sua e que também nos oriente à reflexão do saber-fazer. Se partirmos da premissa de que o aspecto mais eidético da técnica se dá no mostrar-se de sua operação enquanto tal, o questionamento que aqui se faz tem por norte a compreensão sua quando da apropriação humana e o que faz dela aquilo pelo qual - em jornalismo - toma-se por princípio legitimador de diferenciação entre sujeitos comuns e agentes especializados, no sentido de delinear a construção de conhecimento gnóstico.

Quanto à essencialidade do que buscamos, Heidegger nos dá pistas pertinentes ao entendimento a partir doutra concepção recorrente, mas que, a bem da verdade, vai de encontro a este fazer orientado a fins estratégicos. Estabelecemos fins e empregamos meios no tentame de alcançá-los (id., ibid., p. 376), constituindo então aquilo a que podemos inferir como sendo um fazer humano a compor o ser da técnica. Disto, comprendendo-a também na condição de aprontamento, i.e., de um pôr-se- $a^{74}$, temos nela o instalar próprio (instrumentum), que nos direciona- $a$. Neste sentido se dá nossa compreensão do desabrigar; este levar à frente enquanto modo, que se essencializa como intencionalidade donde a ação consciente em si se dá. Mas há que se ressaltar, no entanto, que essa essencialidade, em seu mostrar-se operativo à atividade jornalística, não se dá nos termos de um intencionar enquanto ato mesmo de des-velamento, porquanto, em sentido outro, é tida na condição de apropriação energética das coisas que se encontram à manualidade, cujo fim último não se orienta necessariamente ao telos. O que é tido então por verdadeiro à emergência mesma do presentar-se, nos direciona a uma

\footnotetext{
${ }^{73}$ Cf. Id., ibid., p. 381.

${ }^{74}$ Assomado a este fazer-para, que, em si, é já essencialmente estratégico.
} 
livre relação com o que nos toca a partir de sua essência. De acordo com isso, a correta determinação instrumental da técnica não nos mostra ainda sua essência. Para que possamos chegar a ela, ou pelo menos à sua proximidade, devemos procurar, passando pelo que é correto, aquilo que é verdadeiro. Devemos questionar: o que é o instrumental mesmo? (HEIDEGGER, 2007, p. 377).

Deste questionamento, passamos de uma finalidade técnica ao incomodar-se que se dá na busca mesma de sua essencialidade, que nem sempre se mostra à emergência mesma do verdadeiro. Por outro lado, o que se nos é oculto guia, também, à libertação pela verdade. Por isso este desabrigar emerge tão somente do que é livre e que conduz, de sua vez, o que também vê-se liberto. É, portanto, o que "iluminando oculta, em cuja clareira paira aquele véu que encobre o que é essencial em toda a verdade e deixa surgir o véu como o que encobre"75 e nos direciona à essência.

A noção de instrumentalização operada a partir da e pela técnica, este fazer-por que nos condiciona a fins- $a$, é também concepção recorrente da tradição filosófica concernente à ideia de causalidade. Heidegger retoma esse princípio, para disto seguir adiante, em consonância às quatro causalidades que desocultam o que é a técnica na condição de meio. Tem-se, a princípio, a causa material, tida na forma como algo se nos apresenta. Disto, o que se toma por causa formal, dá-se na instalação do que é material numa dada figura, que constitui ela própria a matéria que de algo é feito. Uma causa final, que em si é já o cerne de qualquer teleologia, i.e., o "sacrifício" para o qual algo é requerido (id., ibid., p. 377), e, então, a que se tem por causa efficiens, que designa o efeito a que algo se destina. O questionamento de Heidegger, a partir dessas quatro concepções de técnica, nos conduz a indagar se, elas próprias, não são insuficientes a ponto de compreender a essência mesma da técnica. Se a recorrência desta noção é também resultado dos princípios operativos da causalidade, por certo há que se considerar que não são nestes o lugar em que instala-se aquilo a que o autor toma como sendo o essente. Do contrário, a técnica enquanto instrumentum permaneceria sem fundamento, no sentido de que não é apenas de causa que se faz seu ser autêntico.

Chegamos, portanto, à ideia de que técnica não se trata tão simplesmente de um meio, o que, na concepção heideggeriana, tem ela à essencialidade a noção de verdadeiro, do desabrigar. Esta ideia à qual se apoia o autor nos remete aos tipos de explicação possível a partir do ato mesmo de conhecer, o que, é também explicação à emergência dos modos

\footnotetext{
${ }^{75}$ Cf. Id., ibid., p. 388.
} 
singulares de nosso saber-operar. Vimos pouco antes, que essa noção conduz à premissa de um levar-à-frente, que à lógica da Modernidade, também nos direciona a outra, qual seja, a de desafiar (Herausfordern). E como tal, este estabelece à natureza as condições e a exigência do que tem ela a nos fornecer (id., ibid., p. 381). Noutros termos, dominamos a técnica pelo desabrigar que nos põe em desafio com a natureza, que, de sua vez, tem algo a nos oferecer e que guia à transformação do que nela exploramos como modo de apropriação energética.

Deste desafiar como forma de exploração e transformação, também passamos ao armazenamento em que se inicia a distribuição do que a princípio desafiamos, pois tornamos a energia apropriada uma subexistência à estratégia mesma do apropriar-com-fins-a. Tem-se, portanto, na noção de desabrigar essa espécie de relação cujo ato em si de desafiar não prevê algo indeterminado, mas caminhos possíveis e dirigidos que nos permitem esse levar-à-frente no sentido de também nos mover a requerer algo pelo tornar subexistente. É, afinal, o que nos desafia a desafiar as forças naturais das quais tiramos o substrato para um seguir-adiante de nosso próprio modo de operar no-mundo.

Nos aproximamos, aos poucos, da particularidade que garantiu a manutenção do jornalismo na condição de atividade. Trata-se menos de assegurar sua existência tendo por apoio tão somente os princípios de legitimidade do que, propriamente, de emergir enquanto desafio à urgência de um querer que nos põe em movimento. Se tivemos de diferenciar os sujeitos que operavam os sentidos das discussões nos espaços públicos daqueles que também o faziam no interior das redações a partir do exercício destes primeiros, é porque o ato em si de especializar é também decorrente do desafio posto pela emergência de um novo agente na sociedade, encarregado de pôr em movimento de continuidade o desejo mesmo de um quererromper que ia de desencontro a ideais e princípios surgidos das novas conjunturas que deram início ao período moderno.

Temos então a base para questionarmos a respeito de um enfraquecimento da normatividade comunicativa em face da atividade instrumentalizada do jornalismo. Em princípio, é também o processo de instrumentalização o que se fez emergir do desafio imposto às condições de existência e continuidade do fazer e pensar jornalísticos, no sentido de dependerem de apropriações energéticas em que se vê ausente um telos no sentido de Bem (Agathon) comunalizado. Ora, como a mera urgência de um querer-levar-adiante o escopo das discussões públicas não assegurava, per se, a continuidade do exercício jornalístico, a solução mais plausível foi esta orientação a partir da instrumentalização. Se a ação operada 
pela atividade então surgida pautava-se por fins guiados à expanção da circularidade de sentidos, à medida que evoluía e intercalava um desafiar e ser-desafiado-por, também se passou a ter como intento a garantia das condições que permitiam o operar jornalístico. Pois o querer fundante de despertar na sociedade a vontade de um romper-com não era, a fortiori, condição primeira à sua existência.

Ainda que tenha emergido da urgência do próprio querer, sua razão mesma de ser enquanto um estar-em-socialidade se justifica tão somente pela dependência a outras atividades? Evidentemente que não. Do contrário, da vontade pura que nos pôs a querer conhecer o outro pelo intencionar enquanto ação comunicativa, teríamos instrumentalizado tudo o mais quando do ordenamento do caos simbólico que nos instituía. É nesse sentido, portanto, que a noção heideggeriana de técnica nos permite a compreensão de nossa própria essência, a ponto de arriscar a asserção de que somos seres de comunicação capturados pelo querer atender a vontade primeira que nos move a algo pelo desafiar a partir de urgências dadas. Também somos, com efeito, seres de técnica.

A partir do que até aqui foi exposto, temos bases conceituais para nos aproximarmos da premissa inicial deste trabalho, que se dá no sentido de entender até que ponto é pertinente inferir a respeito de uma especificidade comunicacional à emergência configurativa do jornalismo. Por hora, entretanto, há ainda o que se discutir a respeito das singularidades suas enquanto exercício, sobretudo no que concerne a dispositivos outros, que, de sua vez, condicionam a formas singulares de desafiar e ser desafiado-por.

Em primeiro lugar, partimos aqui de uma concepção de técnica operada por este desabrigar de que trata Heidegger, que em seu sentido moderno, opera enquanto apropriação energética das coisas que se encontram já à mão. A própria vontade que nos fez atender o querer puro é resultado do desafio emergido do desconhecimento acerca do Outro pela intencionalidade mesma. Seria então a técnica, o dis-positivo que nos guia ao bem comunalizado? Para tanto, tomemos por pressuposto o fato de que algo surgido do desabrigar pode não se voltar, necessariamente, à pacificação ou à solidariedade dos sujeitos. Uma mentira contada ou mesmo uma ação voltada à estratégia de um benefício próprio podem, com efeito, ser resultado de uma intencionalidade desafiada. Do mesmo modo como, se nosso ato de comunicar é também desvelamento que movimenta o desafiar, pode se orientar ao egoísmo, à não compreensão e ao engano conscientes. 
Nesse sentido, não há como inferir que o processo de institucionalização da atividade jornalística apoiado à técnica tenha, em princípio, solapado as ações de comunicação donde emergem os sentidos primeiros. Tampouco obliterado uma razão prática orientada ao telos. Acaso não é ela própria também resultado de discussões, de decisões pontuais e processos outros de racionalização? Não é, em si, o que desafia e que é desafiado responsáveis pelo tipo de exercício jornalístico que se configura hoje, mas um levar à frente que se apoia naquilo que foge ou que não compete ao bem comum.

Desta não-compreensão da própria essencialidade da noção de técnica, a atividade jornalística evoluiu em consonância àquilo que emergia na condição de desafio aos processos que asseguravam o operar maquínico que dava vida ao produto final de seu exercício. Em algum momento, a técnica já posta em operação no sentido de desafiar a urgência de um querer-romper cedeu lugar a tipos outros de necessidade em que se mostrou mais pertinente priorizar o que assegurava o funcionamento das condições que materializavam o produto tido por jornal do que, propriamente, levar as ações comunicativas a espaços outros. Evidentemente, o próprio surgimento do jornalismo foi decorrência imediata da urgência desta segunda, porquanto aquilo que o configurou nada era senão a consonância com os ideais iluministas vigentes, que tinham por princípio a igualdade e a vontade de mudanças.

A necessidade de se aprimorar os mecanismos que faziam operar a continuidade da atividade no sentido de assegurar seu resultado na forma de um produto final foi decorrência da urgência de garantir aquilo que se tomava primeiramente como sendo o mote a seu surgimento, i.e., o desejo de pôr em circulação (ao maior número possível de sujeitos) aquilo que se discutia nos espaços públicos. E conforme se expandiam as sociedades, crescia também a urgência de guiar o pensamento tido por emancipatório para além da jurisdição do espaço donde emergiam os sentidos.

Partamos, portanto, ao seguinte questionamento: entendida a técnica como sendo este desabrigar que põe em movimento o que desafia e é desafiado, como a atividade jornalística dela se apropriou quanto a uma estratégia com fins direcionados ao lucro e à sobrevivência a partir deste? Com efeito, é preciso compreender as singularidades do tipo de intencionalidade para com a técnica na qual mesmo hoje se apoia o jornalismo. Há dois pontos norteadores nesse sentido, quais sejam, o de que técnica é tudo o que assegura o fazer próprio da atividade graças aos aparatos tecnológicos que materializam o produto final, e o de que é ela própria uma espécie de conduta profissional operada em consonância ao funcionamento das 
máquinas. Ao jornalismo, então, ela se mostra nas condições de instrumentum e ethos, que, operando juntos, deram vez à urgência de melhorar a sociedade a partir de uma racionalidade principiada nos espaços públicos, guiada ao interior da estrutura que se engendrou à operação do exercício jornalístico e à sociedade uma vez mais.

Se o operar sistêmico nos distanciou da racionalidade mesma que se arrefeceu diante do operar mecânico de novas tecnologias, por certo há que se pensar numa separação a ponto de resgatar não a independência desses processos que a princípio nada mais têm que ver com o tipo de comunicação que nos fez querer comungar o bem comunalizado, mas uma forma outra de pensá-los enquanto agimos. Uma emancipação, por assim dizer, decorrente de urgências outras e que desafiam as con-junturas e são por elas desafiadas. Uma técnica emnós e para-outrem, afinal, cujo fim último se mostra sempre metafisicamente enquanto telos orientado ao Bem.

Com isso, não se trata de dizer que há algo de errado no fazer jornalístico em consonância com a tecnicização do processo que possibilita o produto último de sua atividade, mas compreender que o há quanto ao modo como pensamos a razão mesma em sua dimensionalidade prática. Acaso é a asseguração do jornal ou qualquer outro tipo de resultado de sua techné o que sequencia o operar do próprio jornalismo? Se assim fosse, bastaria então que removêssemos do processo tudo o mais concernente à relação e ao que nos põe em movimento, quando de sua circulação, a ponto de querer transformar sentidos, porquanto encarregar-se-ia a máquina do restante.

Fica então a pergunta: que é feito do laço social, característico do que se tem nos espaços públicos, quando este é desafiado pela urgência mesma de uma técnica que o regule e dê continuidade? Noutros termos, até que ponto perdemos, à medida em que desenvolve-se a técnica, a especificidade comunicacional que instituiu nossa produção e circulação de sentidos? Por hora, partamos do pressuposto de que este laço entre sujeitos ganha novas dimensões quando da interferência de uma estrutura sistêmica como a do jornalismo, a ponto de o simbólico precisar agora do escopo de nosso relacionar-com-e-para no sentido de apresentar-se à mediação doutra instância. Não se pode inferir que as singularidades desse tipo de medear o tenha apenas incorporado em seu mostrar-se enquanto saber legítimo. Por certo, a técnica adotada e aperfeiçoada pelo jornalismo institucionalizou os processos de ação comunicativa que antes fazíamos operar noutros espaços. Mas ela própria não é condição primeira dessa lógica operativa, porquanto mesmo o que antes nos dis-punha a relacionar pela 
vontade do querer-romper era, em princípio, o que desafiou a necessidade de compreender e nos fazer compreender no mundo à sustentação dos sentidos.

Se nos deixamos capturar pelo dis-positivo enquanto encontrar-se que se apresenta como condição de satisfação ao querer fundante do relacionar pela intencionalidade, foi porque, em última instância, também a proaíresis (vontade) de estar-com-e-para nos desafiava a todo instante. Por isso nos dis-pusemos a codificar o simbólico, a facilitar o que nos pacificava, a agir no sentido de um entendimento mútuo e, sobretudo, a produzir sentidos que apenas na relação eram engendrados a ponto de sustentar a compreensibilidade nossa. Tivemos então de adotar técnicas específicas que assegurassem tudo o mais, muito embora não a título de estratégia, mas tão somente de entendimento solidário a presentar-se enquanto Bem comunalizado. Do contrário, nossas relações pautar-se-iam por tentativas infindas de dominação mútua.

Se de processos técnicos também se constituiu aquilo que nos pôs-a-relacionar sem que se perdesse a essencialidade que lhe é concernente, seja talvez correto afirmar que não tenha sido o operar da técnica aquilo que condicionou à instrumentalização do ato mesmo de comunicar. Deve de haver algo recôndito nessa lógica, que ainda não enxergamos, e que oculta esta essência de que trata Heidegger. Devemos compreender que o desabrigar que nos põe à frente não é necessariamente um fazer humano. Os frutos duma árvore são também resultado do que ela, na condição mesma de organismo, desafiou a ponto de assegurar a continuidade sua enquanto existir. Mas o desafiar, em seu aspecto moderno, nada tem que ver com a urgência do que se apresenta enquanto natural pelo intencionar. Na condição de apropriação energética do que se encontra aí, é ele a configuração de um pôr-se-a-subexistir, no sentido de tornar outros elementos tão somente um instrumentum a serviço da própria razão prática de uma técnica da qual se lança mão.

O que assegura o exercício jornalístico em sua dimensionalidade técnica não é, em princípio, o elemento fundante à emergência mesma do que é natural, mas também um consumir de energia das coisas mesmas que se nos vem de encontro pela urgência. É preciso então enxergar não o que a técnica fez ao jornalismo e, portanto, à comunicação quando do pôr-se-a-relacionar, mas observar o modo específico pelo qual o jornalismo se apropriou da razão técnica e dela fez instrumentalizar a prática que instituiu o sequenciar de si enquanto tal.

É necessário considerarmos aqui ambas as concepções de técnica. Sendo uma concernente ao tipo maquinal e que não ocorre somente no e para o homem (e, portanto, mais 
recorrente quando se trata de analisar o que configura o fazer jornalístico) e outra, por sua vez, que institui um dos atributos de nossa capacidade mesma de estar-em-comunicação, qual seja, aquilo que se mostra à urgência de um querer atender ao querer primeiro. Numa, portanto, técnica é procedimento, ao passo que, noutra, nada é senão dis-positivo. Partindo então de ambas as concepções, fica pendente apenas a compreensão do que se mostra enquanto urgência do ato mesmo do desabrigar, i.e., o que faz operar a urgência daquilo ao qual algo se destina.

O que nos conduz, por sua vez, ao seguinte questionamento: de que modo se apresenta a armação à configuração mesma da atividade jornalística? Se esta é o ato em si do desafiar enquanto apropriação energética, não haveria um fim último ao exercício do jornalismo a se mostrar na condição de telos e não necessariamente à subexistência das coisas mesmas em razão de uma praticidade instrumental? Para tanto, regressemos à ideia que nos serviu de base. O jornalismo se tornou possível na ambiência societária por conta da urgência de estarem os sentidos produzidos e em constante circulação pelo pôr-se-a-comunicar adiante dos espaços que lhes serviram de embrião. Sendo assim, tivemos de atender a uma necessidade que se tornou possível apenas quando da vontade em nós desperta de querer atendê-la. Nossa incapacidade de expandir os sentidos para além donde inicialmente foram engendrados se viu desafiada a ponto de nos mover a estruturarmos novos modos de relação e que requeriam tipos outros de técnica. O fazer técnico, nesse sentido, há muito em nós operava, o que faz da atividade jornalística tão somente um processo especial de continuidade em seu aspecto mais moderno, i.e., de redução energética à emergência mesma de um tornarsub-existência em razão do elemento prático da operação jornalística.

Não há uma dubiedade ou contradição no modo como se apresenta a técnica nesse espaço, porquanto se trata de experiências diferentes que se instituem pelo ato mesmo de desabrigar no intencionar daquilo que se nos vem de encontro. A armação no processo maquínico que materializa o produto final do exercício jornalístico se apresenta então quando da necessidade de pô-lo em operação, i.e., a partir do instante em que a restrição da circulação de sentidos na esfera pública foi desafiada ao surgimento de uma atividade que a evitasse. Todo agir técnico, uma vez configurado à teleologia de um Bem comunalizado, será sempre emergência nos termos contrários de um tornar-sub-existente enquanto órganon de uma praticidade egológica. 
Chegamos, assim, ao atributo primeiro da técnica, aclimatada à discussão de tipos outros de essencialidade concernentes ao jornalismo e à constituição ontológica de um estarem-comunicação. Este, por sua vez, nada tem que ver com um perigo, posto que, em princípio,

a ameaça dos homens não vem primeiramente das máquinas e aparelhos da técnica cujo efeito pode causar a morte. A autêntica ameaça já atacou o homem em sua essência. O domínio da armação ameaça com a possibilidade de que a entrada num desabrigar mais originário possa estar impedida para o homem, como também o homem poderá estar impedido de perceber o apelo de uma verdade mais originária. (HEIDEGGER, 2007, p. 390).

É, pois, uma questão de sensibilidade. De descortinar o que há de recôndito nas entrelinhas do que nos desafia. Em princípio, estávamos já entregues a um destino que se delineava na condição de barbárie, donde fizemos emergir relações de entendimento como resposta ao desafio que nossa própria essência enquanto existir-no-mundo nos impôs. A partir de então, tudo o mais se mostrou enquanto dis-positivo a nos capturar para algo, conquanto permanecesse em nós a vontade mesma do querer fundante. De modo não diferente se deu a emergência do fazer jornalístico, que intentava a urgência de não deixar fenecer o resultado do pôr-se-a-comunicar, muito embora sua prática e objetivos tenham se direcionado mais e mais a uma instrumentalização que atendia aos ditames de um mercado em constante desenvolvimento.

O que nos faz retomar o questionamento há pouco feito, qual seja, de saber se a instrumentalização do jornalismo não acarretou o fim dos tipos singulares de relação que mantínhamos antes da urgência de seu nascimento. Por certo, a técnica maquinal dos primeiros aparatos que davam conta do processo de materialização de um produto foram responsáveis não apenas pela fixação do simbólico previamente engendrado em meios duráveis como, em última instância, asseguraram a amplitude de sua reprodução.

É possível até considerar que, somada à lógica de um dispositivo e de uma técnica em que a realidade mesma se viu desafiada, o início do fazer jornalístico muito teve que ver com um tipo especial de querer até então não visto, qual seja, o que nos pôs em vontade de luta e tudo o mais que ia de desencontro a quaisquer desesperanças. É pertinente até diferenciarmos essa forma de querer daquela que nos instituiu na condição de sujeitos e que se nos orientou às vontades de um estar-junto, porquanto víamos unidos por laços e vivendo con-forme as 
convenções de um contrato há muito estabelecido. Mudamos, de modo semelhante quando do início de nosso relacionar, o direcionamento do querer puro que sempre nos movimentou.

Se antes o desconhecimento e o temor da solidão se mostravam como nêmeses ao que nos instituía enquanto humanos, a vontade mesma do romper-com nos orientou a ponto de compreender que a pacificação assegurada no contrato pela transferência de responsabilidade à figura de um só já não mais garantiam que todo o restante se direcionasse ao Bem comunalizado. Por isso, não se pode inferir acerca de regressos, mas tão somente de avanços pontuais que se permitiam à luz de toda razão possível. Essas condições desafiaram a urgência de um tipo singular de atividade pela tomada de consciência, desabrigando então a vontade de levar adiante o próprio esclarecimento. E da treva de toda incerteza, fizemos emergir o querer-clarificar das discussões atinentes à racionalização a ponto de chegarem a outros corações e capturá-los à vontade de atender o querer-mudar.

Até aqui, considerou-se um tanto mais pertinente compreender a noção de técnica quanto à sua dimensão que concerne a essência mesma de um desabrigar pelo desafio a se mostrar menos enquanto intrumentalização do que na condição mesma de telos, pois deste modo se principiou a atividade jornalística. Por outro lado, é tão necessário quanto, observar a maneira com a qual o jornalismo atribui à técnica um fazer último voltado a estratégias comerciais e, sobretudo, à asseguração do que operava seu propósito de ser e estar quanto a uma materialidade que se fazia notar. Noutros termos, a dimensão de instrumentum encerra em si a forma como hoje conhecemos o exercício próprio ao campo. Partindo disso, se faz necessário outro questionamento: se a técnica instrumentalizada do jornalismo na condição de armação não solapou nosso relacionar essencialmente comunicativo, teria ela então nos direcionado a outro tipo de ação relacional? Mudamos, por certo, os modos como nos interacionamos, sobretudo no que diz respeito à liquidez de tempo e espaço então pulverizados pelo medear de aparatos tecnológicos. Do mesmo modo como, apesar da institucionalização de uma atividade que nos era orientada pelo pensamento crítico, a ubiquidade da figura do outro não foi de todo obliterada, porquanto o próprio exercício jornalístico se viu dependente dos acontecimentos na esfera do vivido cotidiano. Pois as máquinas, eo ipso, nada tinham que ver com a realidade experimentada. 
Se partirmos do pressuposto de que os termos de um in-comunicar não assinalam o fim dos problemas que lhe são inerentes ${ }^{76}$, também a técnica não se assegurou de tal. O medo da incompletude e da condição de conflito perpétuo sempre se apresentou em nós também na condição do que move-a-alguma-direção, porquanto ele próprio é já um tipo singular de querer. Agora, por outro lado, se observa um medo bastante específico: o de permanecer na escuridão da ignorância; sentimento este que principia toda a teleologia do Iluminismo.

Se do medo do desconhecimento em relação ao Outro fizemos emergir a necessidade de uma pacificação pelo relacionar, foi também no temor de permanecer aos grilhões da desrazão que nos pusemos em vontade de romper-com. Trata-se, portanto, de dois momentos distintos em que nossas ações voltaram-se à transferência. No primeiro, transferimos as responsabilidades à figura de um só que se nos assegurasse o bem comunalizado e orientasse tudo o mais pelo estar-em-pacificidade, enquanto, no segundo, transferimos à atividade jornalística a missão de executar o que de início não pudemos, i.e., despertar em todos o querer fundante que move e rompe. Em ambas as situações, delegamos responsabilidades sem que se perdesse de todo a autonomia. E em ambas, também, adotamos técnicas em decorrência de urgências e desafios, muito embora o modo como estas foram apropriadas pela atividade jornalística tenha se voltado à continuidade dela própria por vezes desprovida de um querer-romper e em consonância tão somente à lógica doutras instâncias, sobretudo a de mercado.

Na condição de instrumentum, a técnica no jornalismo erigiu as bases para a criação de deontologias específicas que não apenas garantiam o próprio fazer como, de modo semelhante, lidimavam as ações daqueles que então se especializavam a ponto de se diferenciarem dos demais sujeitos. Estes, apesar de também produzirem e circularem sentidos, não partilhavam do domínio das regras ou do maquinário técnico que operava a materialização do produto final. A não ser, evidentemente, que se dispussessem a aprendê-los, conquanto se compromissassem também a adotar essas primeiras como código de conduta.

Da adoção de regras e do aperfeiçoamento operativo do que então passou a configurar a atividade de jornalismo, chegou-se a tipos outros de conduta que convergiram a um único princípio, qual seja, o de eficácia. Noutros termos, conforme evoluía seu exercício, migrou-se da urgência de um despertar do querer a esta forma de garantia de que o processo técnico, eo

\footnotetext{
${ }^{76}$ Considerando-se aqui o fato de que não bastaram dis-positivos, desafios ou mesmo o querer puro a ponto de se resolver de vez o problema com o Outro no sentido de um estar-junto-e-para pela pacificação e Bem comunalizados.
} 
ipso, daria conta de tudo mais que o fosse. Ainda que seja um fenômeno em nós e para nós, se mostra menos como um objeto (proprietas) a mais do que como esse modo singular de acontecer que só é quando ocorre e ocorre quando o é num horizonte de metas que é sempre tendência ao con-viver pacífico.

Por não ser a comunicação uma mera coisa, a própria noção de eficácia se torna um tanto deslocada quando se trata de aclimatar uma à outra, no sentido de que, quanto mais eficientes forem as técnicas operativas, tanto mais o será também nosso modo de comunicar. A pertinência se daria apenas caso fosse o fim último da vontade que nos move a comunicar tão somente a mera consecução de um resultado estratégico. Não se pode também atribuir à noção de eficácia o telos de nosso pôr-se-a-relacionar, como se houvesse nisso - e tão somente assim - a razão última da condição mesma de estar-em-comunicação-com-o-outro. Se há um escopo no encontrar-se do querer fundante, nada é senão que o Aghaton comunalizado, a solidariedade mútua e o entendimento ético a que chegamos quando do intencionar pelo presentar-se ôntico do Outro a mostrar-se sempre enquanto primado ao aberto do ser.

É nesse sentido, portanto, que a eficácia técnica e ferramental do jornalismo contraria o tempo de nossas relações, no sentido de que, ao fim, as pausas características de argumentações e raciocínios cedem vez à velocidade de transformação opinativa. Isso não significa inferir que estão solapadas as formas singulares de racionalidade pelo simples fato de que agora, se veem transferidas a uma instância mediada. Mas, por sua vez, compreender que é possível estarmos diante doutra urgência, qual seja, a de tentar recuperar a sugestionabilidade de um tempo que nos fora aparentemente tomado, no sentido de aproveitar a potencialidade comunicativa do jornalismo a ponto de criarmos espaços outros de discussão, como os que deram-lhe sentido e origem. 


\section{DA ANTINOMIA ENTRE COMUNICAÇÃO E JORNALISMO}

\subsection{Informar Enquanto um Pretender-se-comunicativo}

Epistemologicamente, do mesmo modo como o fenômeno comunicacional, a noção de informação não é estável a ponto de propormos com clareza indubitável que a busca de um verdadeiro que se dá no-mundo a partir do ato informativo partilhe, a princípio, dos mesmos atributos quanto ao eidos próprio ao estar-em-comunicação. Mas até que ponto, agindo como princípio operativo do exercício mesmo, há no que aqui compreendemos como pretender-seinformativo algo que possamos considerar como sendo próximo ou semelhante à noção de comunicar?

Em primeiro lugar, consideremos a noção de um agir orientado pela busca do verdadeiro a partir do ato mesmo de narrar-a-respeito-de. Se o considerarmos na condição de pretensão ${ }^{77}$, perceberemos que sua orientação se volta à possibilidade de um pôr-se-arelacionar nos termos de uma comunicação operada pelo negociar responsável e solidário enquanto modo de estar-para-o-outro. Mas isto, por outro lado, se mostra menos como informar do que, propriamente, a sensibilidade que se tem de perceber o que se passa na realidade experienciada pelo estar-em-comunhão. Noutros termos, esse agir informativo de que tratamos se apresenta como instância acabada da vontade mesma que se manifesta a partir de um agir primeiro, i.e., o de buscar no mundo circundante aquilo que se toma por verdade e, disto, ordenar os sentidos até o ponto de comporem estes um todo significativo ao escopo da atividade jornalística.

A noção de ordenação nos será cara ao entendimento da análise eidética quanto a um pretender-se-informativo como modo de intencionar o que vem-de-encontro no mais essente do in-comunicar. Mas, por hora, centremos as observações em torno da seguinte questão: se a busca de um verdadeiro emergente como forma de pôr-em-relevo o vivido se mostra na condição de possibilidade ao exercício do jornalismo concernente ao agir informativo, é possível inferir que o saber gnóstico que legitima sua techné seja então construído a partir de saberes outros e alheios à própria estrutura do campo?

\footnotetext{
${ }^{77}$ Cuja finalidade se fundamenta não na comprovação de uma verdade em si, mas pela impressão de que houve rigor ético na busca.
} 
É necessário trazer à luz a noção de que, por ter se configurado a partir do pôr-se-acomunicar com o Outro, o agir orientado por um pretender-se-informativo foi, antes, menos uma espécie de coleta na qual se ordenou coerentemente os eventos característicos de um acontecer do que um negociar de sentidos à ordenação em consonância com o rigor deontológico da estrutura do campo. $\mathrm{O}$ ato mesmo do narrar, a bem da verdade, encerra em si duas pretensões: a de ordenar-para-informar e, disto, a de despertar-para-compreender.

Se tomarmos por norte o início da atividade jornalística, notaremos que, em ambas as pretensões, sua narratividade opera como dispositivo que prepara aos sentidos em dois momentos específicos: a) o instante da relação entre sujeitos jornalistas e não-jornalistas que os captura à urgência de uma negociação comunicativa a se orientar pela ordenação dos eventos do vivido e; b) o momento específico da transformação dessa ordenação em produto mediado, cujo propósito é regressar ao mundo vivido a ponto de, por ser ela própria um dispor- $a$, despertar os sujeitos à compreensão de um todo já organizado pela ação de informar.

Logo, a intencionalidade informativa, enquanto pretender-se à ordenação do caos dado aprioristicamente no-mundo, é também condição à formulação deontológica que se convencionou em torno de uma ação outra que evidencia o caráter ordenador do próprio informar, i.e., a de noticiar-a-respeito-de. Percebam: não bastou tão somente uma organização de tudo o mais que se apresentasse como desordem a ponto de se fazer urgente um informar pela coerência. Foi preciso, antes, criar a impressão de que esse pretenderinformar era em si um procedimento rigoroso cujo intento se orientava pela busca de um verdadeiro enquanto modo único de pôr em relevo.

Como o agir informativo não era, em princípio, uma performance restrita à figura do jornalista - posto que, qualquer um, em qualquer lugar, se vê capaz de tal -, se mostrou urgente que um princípio operativo do próprio informar-sobre na condição de organização e despertar de compreensão diferisse do tipo de agir comum a outros sujeitos que não partilhavam das regras e da lógica operativa do campo jornalístico. Noutros termos, a ação de informar por parte de um jornalista nada teria que ver com a mesma ação praticada por um sujeito não-jornalista, porquanto este primeiro, à luz de uma racionalidade especial, adotaria por finalidade um rigor enquanto busca pelo entendimento. Informar, para o jornalista, se tornou como tal tão somente por encerrar em si um proceder legítimo convencionalizado por essa espécie de agir-com-fins-ao-noticiar. 
A questão que se levantou não foi ainda resolvida. Até que ponto o pretender-seinformativo no ato mesmo de noticiar se apresenta como apropriação de saberes outros e que, por sua vez, se legitima tão somente por ser ele próprio um saber original? Por certo, alguns dos princípios operativos no jornalismo só se sustentam pelas impressões de que não há neles uma arbitrariedade inerente. Mas o agir enquanto pretensão informativa apresenta uma especificidade singular que aqueles que se situam no mundo vivido - e, portanto, fora da estrutura do campo - não a têm, qual seja, a de fazer com que os próprios enunciados adquiram consistência a ponto de se alçarem na condição de discurso. Noutros termos, aquilo que se enuncia no jornalismo, por um agir orientado pelo informar-com-fins- $a$, é apresentado no formato de uma pretensão discursiva que é validada por aquilo que se convencionou chamar de notícia.

O tipo de saber original que movimenta a atividade jornalística enquanto apropriação é, com efeito, uma espécie de saber não-legítimo no sentido de estar aquém da potencialidade discursiva daquilo que se enuncia em jornalismo. Noutros termos, da busca por um verdadeiro à emergência do vivido donde circula o saber originário, o exercício mesmo passou à condição de verdade legítima pela impressão do rigor que traz em si qualquer uma de suas pretensões. A verdade que se fazia circular no vivido foi, em decorrência da evolução do exercício de transformar em discurso os saberes pelo noticiar-a-respeito-de, aos poucos sendo considerada como ilegítima por não haver nela os mesmos princípios que se apresentavam na discursividade jornalística a ponto de creditarem a confiança na certeza dos eventos ocorridos e dos quais se extraía o tipo de informação necessária à continuidade da construção de sentidos.

É confiável, por conta da impressão que se mostrou como pretensão do exercício jornalístico, aquilo cujo ato mesmo de informar-sobre tenha necessariamente passado pelo rigor dos mesmos critérios adotados pela estrutura do campo. Do contrário, o que se enuncia enquanto informação no espaço do vivido nada é senão que um tipo de falar-a-respeito-de, cujo fundamento não opera em consonância à busca de uma noção de verdade a ser extraída do real experienciado, mas enquanto ação descompromissada, por assim dizer, com a busca de um verdadeiro emergente.

Enquanto entidade discursiva, a apropriação dos saberes originários se mostrou como condição de possibilidade à formulação de um saber próprio, lidimado pelo rigor deontológico que lhe é específico e pela impressão mesma de que, neste, se encerra o dis-positivo que nos 
toma à vontade de um bem comunalizado que é sempre telos no mais essencial de seu devir como modo de abertura futuralizada. É preciso, então, enxergar o procedimento de se noticiar-acerca-de, a ponto deste se alçar enquanto discurso à pretensão doutro agir específico no tipo de narratividade jornalística, i.e., o de normalização.

Dessa normalização, que é também resultado da urgência de se evidenciar a impressão de que existem critérios à obtenção do verdadeiro operada pelo rigor de uma postura ética inerente, o jornalismo passou a regular a ação mesma do informar-sobre a partir de uma uniformização consensual do modo como os enunciados decorrentes das negociações de sentido com o vivido eram transformados em discurso. A notícia, tida então enquanto padronização do agir na forma de um pretender-se-narrar, uniformizou também o ethos do especialista, porquanto já não era possível se orientar conforme as regras do campo sem, antes, aderir a todo este processo de normalização discursiva. A dimensão epistemológica da ação do informar se apresenta como sendo a própria pretensão de que, agindo como busca de uma verdade que se dá no modo do relatar-a-respeito-de, o exercício jornalístico se apresente também na condição de um pôr-se-a-relacionar pelo negociar semântico no mostrar-se da meta de um estar-para-outrem.

É preciso considerar, por outro lado, que o agir na condição mesma de um pretenderse-informativo, cuja orientação é regulada uniformemente a partir do querer-noticiar-o-quevem-de-encontro não é uma criação própria ao espaço de atividade do jornalismo. Por certo ele o padronizou a partir de convenções e tensionamentos, muito embora antes, quando da formação das primeiras sociedades, havia já a urgência de se relatar o que acontecia num determinado espaço a outros cuja a ação do acontecer não se lhe estendia. Tanto em forma quanto no conteúdo, o que se toma por notícia no jornalismo nada é senão que um aprimoramento do pôr-se-a-relatar-sobre, que antes se viu operado pela música nas composições poéticas populares dos jograis ambulantes ${ }^{78}$. O que se pode questionar então é: se exercia jornalismo mesmo antes deste se apresentar enquanto tal? Evidentemente que não.

Como o tipo de configuração que dava forma às sociedades era todo ele operado à emergência do pôr-se-a-comunicar, o que se teve antes da instituição do jornalismo eram preâmbulos da urgência que lhe serviu de embrião ao próprio surgir, sendo que, com efeito, se apresentava já como essencial ao modo de sequenciar o que construíamos de sentido. Noutros

\footnotetext{
${ }^{78}$ Cf. KOVACH, Bill; ROSENSTIEL, Tom. Os elementos do jornalismo: o que os jornalistas devem saber e o público exigir. - 2. ed. - São Paulo: Geração Editorial, 2004, p. 37.
} 
termos, enquanto exercício que se institucionaliza pela legitimidade de uma ação mesma de informar, continua sendo o jornalismo essa espécie de "invenção moderna". Por outro, no entanto, a essencialidade que lhe é intrínseca como dispositivo que nos move a atender a vontade de algo, se mostra um tanto mais primevo que seu próprio surgimento ou das premissas que lhe serviram de mote ao continuar-de-si.

A diferença, então, consiste no fato de que também esse agir no jornalismo enquanto pretender-se-informativo alçou-se à institucionalização a ponto de a própria notícia apresentar-se menos como um princípio operativo surgido da urgência de se levar adiante os sentidos do estar-em-relação, do que de ser ela uma disponibilização enquanto produto. Não há neste processo algo que se possa tomar por comunhão, a menos que, uma vez apropriada pelos sujeitos componentes do público, se mostre como condição de possibilidade à construção de sentidos outros.

Há ainda outra peculiaridade na ação informativa do jornalismo, qual seja, a de possibilidade de renovação do ato mesmo de relatar tão somente quando da ocorrência de um acontecimento tido por inesperado.

Noutros termos, a normalização discursiva do exercício jornalístico pela ação do informar-sobre é reguladora do modo como se enuncia, e não, propriamente, daquilo a que se enuncia. Tendo como sustento de si, o jornalismo precisou também padronizar o formato específico com o qual o resultado de sua apropriação do vivido seria então posto-a-informar. Pois não bastou instituir-se enquanto locus donde se discursa, já que, para tanto, tinha de aprimorar um mecanismo sofisticado a ponto de fazer com que outros reconhecessem nele um saber legítimo. Por isso a notícia opera a partir de uma urgência outra da que tínhamos quando os acontecimentos de nossa experiência sensível tinham de ser relatados a outros espaços donde não chegava a circularidade dos sentidos então construídos.

Do ponto de vista normativo, o ato do noticiar-a-respeito-de é essencialmente interação de força entre as instâncias da atividade jornalística, no sentido de que, para que haja uniformização, é necessário antes uma espécie de acordo tácito a ponto de fazer com que o padrão alcançado não seja, em vez de uma convenção, apenas um mecanismo arbitrário com o qual se intenta a consecução de fins estratégicos. Nada impede, evidentemente, que o exercício do jornalismo o faça enquanto tal, muito embora ruir-se-ia (na condição de atividade mesma) quando da percepção de suas pretensões desfiguradas. 
Se o que se toma então por notícia é esse princípio normalizador que opera no sentido de passar ao público a impressão de que, nessa ação legítima, exista algo importante a ser informado, por certo há também neste aquilo que se mostra um tanto tautológico quanto a um esgotar-se-em-si-mesmo. Os sentidos que construímos e fazemos circular na espacialidade do vivido são, de sua vez, apropriados pelo exercício jornalístico a partir dos princípios operativos que lhe são próprios, como o ato do informar em si. Assim, as singularidades dos eventos de quaisquer acontecimentos são transformados em narrativa potencialmente expandível do ponto de vista discursivo - pela techné que lhe é própria -, até regressar ao vivido. Como então, neste movimento, a lógica que configura o exercício pode ser vista fora dos parâmetros de um fazer tautológico? Para tanto, é necessário compreender a noção de informação para além de sua dimensionalidade concernente à novidade que surpreende e, de algum modo, perturba a ordem vigente das coisas pela ação mesma de um ordenar. Se acaso removermos como princípio essa pretensão de dar sentido ao mundo a partir de um ordenarcom-fins- $a$, o que nos restaria afinal e que, de todo modo, pudesse ser tomado ainda enquanto intencionalidade informativa?

Noutros termos, se desconsiderarmos momentaneamente a noção de informação enquanto ordenação do caos dado a priori no-mundo, com que, afinal, emergeríamos enquanto razão outra de princípio operativo? Estaria nisto algo a que possamos considerar como sendo especificamente comunicacional no ato mesmo do informar? Partimos aqui do pressuposto de que informar e comunicar, enquanto acontecimentos performáticos, não partilham dos mesmos atributos que lhe são de essência. Por outro lado, têm ambos uma ambiguidade quanto às noções epistemológicas que deles se pode observar.

Iniciemos, pois, com a ambiguidade epistemológica concernente à noção de informar. Quando da recorrência ao étimo que lhe serve de raíz, informação deriva do termo em latim informare, que se refere à capacidade de modelar algo, dar-lhe forma e algum significado coerente. Esta concepção, um tanto mais primitiva de se observar a essencialidade da informação, foi comumente aceita no século XII, quando a atividade jornalística sequer via-se como embrião ${ }^{79}$. Embora os eventos que se lhe mostraram como desafio à urgência primeira tenham se desenvolvido períodos antes, até então, o modelar de algo não tinha necessariamente que ver com algum tipo de acontecimento, porquanto atribuía-se sentido a fenômenos que não ocorriam.

${ }^{79}$ Cf. WOLTON, Dominique. Pensar a comunicação. Brasília: Editora Universidade de Braília, 2004. 
Disto, atravessemos três séculos adiante, quando a atribuição que se fazia da noção mesma de informação passou a designar tudo o qual nos punha "ao corrente de qualquer coisas" $" 80$, i.e., aquilo que nos movia ao encontro e entendimento da ocorrência de algum evento. Nesta segunda concepção, a ideia de que há algo acontecendo é cara à essencialidade da noção que se confere ao sentido do termo, pois, enquanto fenômeno performático, o ato mesmo do informar se apresentava como uma perturbação de uma ordem primeira, e que, de algum modo, punha a própria realidade vivida em movimento no sentido de estarmos em consonância às mudanças do próprio real. De todo modo, o que precisa aqui ficar claro, é o fato de que não se trata de uma evolução no modo de se atribuir sentido à noção mesma do ato de informar, posto que ambas as concepções estão, cada qual, operando semanticamente no mesmo fenômeno.

Percebam então que, tanto uma quanto a outra, enquanto ações que são, remetem a uma última não menos pertinente, qual seja, a de ordenar. Se, na primeira, damos forma a algo no intento de organizar os sentidos da forma como este se nos apresenta, na segunda, perturbamos a realidade vivida para construirmos uma noção de verdade que componha um todo significativo à compreensão. Observemos:

si reflexionamos en la etimologia del término in-formación, descubrimos que designa a lo que tiene 'forma', entendida esta como estructura. Lo contrario es lo que no tiene forma, lo que no tiene ser; información por eso es aquello que está en la clave de la existencia, en el orden que nos constituye y nos da presencia en el mundo. (LIHON, 1985, p. 38).

Centremos então nossas observações no seguinte problema da visão lihoneana de se debruçar sobre o fenômeno informativo: se o informar, enquanto ação, é parte do que nos constitui na condição de humanos, e se, de modo semelhante, é a comunicação como performance que dá sentido ao que nos constitui, teríamos então uma natureza essencialmente ambígua? Mais até: do ponto de vista ontológico, as ações de informar e comunicar, enquanto essencialidade nossa, estariam a nós restritas?

Em primeiro lugar, consideremos a noção de informação não como uma capacidade que se esgota em si, mas um fenômeno que se mostra no intencionar daquilo que nos vem de encontro pelo estar-em-comunicação. Se partirmos dessa premissa, mesmo o fato de que informar é uma ação epistemicamente objetiva perderia o propósito enquanto tal, porquanto

\footnotetext{
${ }^{80}$ Cf. Id., ibid., p. 504.
} 
há, em jornalismo, a singularidade de pessoas que se movem ao construir de sentidos. Nesses termos, há uma característica quanto ao ato mesmo de informar-a-respeito-de, que se apresenta à configuração fenomenológica de um querer-informar-a-respeito-de.

Por certo, como dado autômato, a informação armazenada a partir de uma lógica coerente e computada por um sistema que de algum modo a processe nada tem que ver com as vontades nossas. Dito noutro modo, não se pode tratar de um aspecto ontológico da informação fora dos termos de uma teleologia da vontade em consonância ao querer fundante em seu mostrar-se enquanto pôr-se-a-informar. Esse tipo de ontologia de primeira pessoa ${ }^{81}$ quanto ao pôr-se do informar-com-fins-a é sempre o se-mostrante seu na condição de telos ao in-comunicar. À ausência dessa configuração, o resultado mesmo de todo informar ver-se-ia tão só como aquilo que, em seu presentar-se, se dá na perspectiva de um voltar-se-àestratégia do mero informar-para.

Nos termos de um informar epistemicamente objetivo, não temos de todo um controle quanto ao tipo de fluxo informativo que é operado à lógica de processamento de uma máquina. Mas percebam: ainda que qualquer sistema maquínico opere independentemente de nossos desígnios, a capacidade que lhe é singular quanto ao operar-em-e-para-si é por nós aprimorada e desenvolvida. O que se observa então, é que a informação a se apresentar na condição de dado é precedida de um fazer próprio que, a princípio, se mostra ontológico por natureza. Não se trata de propor aqui um tipo de ontologia característica ao exercício jornalístico, mas, na atividade mesma de seu exercitar-se, enxergar aquilo que se apresenta enquanto ontologicamente orientado por ser de início a condição de satisfação (preenchimento) do querer puro que nos move a estar-para-outrem.

É preciso considerar o modo como a noção de informação se configura no jornalismo. Por tratarmos então de um tipo de agir que é ontologicamente orientado, observaremos o modo como, enquanto performance, a informação se nos apresenta como nivelamento ${ }^{82} \mathrm{em}$ seu mostrar-se na condição de telos.

Nos apropriaremos dos níveis ${ }^{83}$ descritivo, explicativo, preditivo, prescritivo e um último atinente ao que se considera como sendo emotivo, para observarmos o modo como se apresentaram na atividade jornalística no decorrer de seu desenvolvimento. Essa observação

\footnotetext{
${ }^{81}$ Cf. SEARLE, John. R. Intencionalidade. - 2. ed. - São Paulo: Martins Fontes, 2002.

${ }^{82}$ Cf. LIHON, Danilo Sanchez. Teoría y practica de la informacion. Lima, Peru: INIDE, 1985.

${ }^{83} \mathrm{Cf}$. Id., ibid.
} 
se faz necessária no sentido de, por ser o pretender-se-informativo uma postura epistemológica no jornalismo, pôr em relevo suas singularidades se quisermos enxergar nisto algo que se nos apresente enquanto especificamente comunicacional. Será também preciso observar o que institui o fenômeno do in-comunicar a ponto de inferir se acaso partilham ambos dos mesmos atributos ou se, com efeito, operam por princípios antinômicos e cuja natureza essencial de um nada tenha que ver com a que se mostra noutro.

Partamos ao primeiro nível do fenômeno informativo de que trata Lihon, acerca da descrição como princípio operativo do ato mesmo de informar-a-respeito-de. Neste, o atributo da informação enquanto agir se mostra em seu aspecto factual, i.e., aquilo que, da realidade vivida, se considera como sendo um acontecer. É comum à atividade jornalística a busca de um verdadeiro emergente nesse evento a partir de um relatar-com-fins-a que lhe é próprio ao tipo de narrativa, sendo operado, como antes visto, pelo ato em si do informarsobre. Noutros termos, é um nível informativo usual ao exercício, diferente daquele que se toma por explicativo, cuja finalidade é fundamentada pela eficiência mesma quanto ao modo de informar.

Lidamos então com um nível um tanto mais complexo se comparado à ação de relatar tendo por princípio um ordenar-para, porquanto o que se extrai agora do fenômeno é a explicação em torno do organizar-sentidos, que é sempre finalidade de qualquer fazer científico. Muito embora o exercício jornalístico nada tenha que ver com uma ciência ${ }^{84}$, o esforço que despende quanto a um interpretar-das-coisas-mesmas se mostra como tentativa de explicar o mundo pela ordenação. Esta é fundamentada tão-só pela apresentação concreta (em quaisquer uma de suas mediações possíveis) de evidências que atestam aquilo do qual por vezes não se presenciou ou afirmou.

Nestes dois primeiros níveis, portanto, o ato de informar no jornalismo opera no sentido de fundamentar a própria pretensão de busca por um verdadeiro à emergência do vivido, impressionando pela seguridade mesma de que toda e qualquer evidência se encontra não em sua estrutura enquanto campo, mas na espacialidade donde se veem os acontecimentos, i.e., no próprio mundo experienciado.

\footnotetext{
${ }^{84}$ Porquanto se constituiu e se institucionalizou como atividade de busca pela verdade mesma das coisas a partir de um relatar de eventos por vezes não presenciados e que se orienta, então, pela negociação donde emerge uma confiança ao pôrse-a-relacionar.
} 
À medida em que se aprimorava a técnica jornalística, enquanto instrumentum de seu saber-fazer, também evoluía um terceiro nível concernente ao modo como opera a informação, qual seja, o preditivo. A este respeito, o que Lihon considera como sendo a predictibilidade do fenômeno informativo nada é senão que a atribuição de valores probabilísticos a todo tipo de informação que serve como banco de dados, para que, disto, se preveja as regularidades a ponto de obter pela testabilidade resultados outros. Este nível informativo é próprio ao fazer maquínico, não tendo em si algo que opere especificamente a partir de algum princípio jornalístico, a menos que consideremos a necessidade que a estrutura do jornalismo tem de armazenar o resultado da própria atividade como conjunto de informações acessíveis. De todo modo, não há nisso algo que seja essencial ao exercício ou ao dispositivo que toma os jornalistas a um querer executá-lo, ficando então restrito à lógica operativa de uma tecnologia.

Tratemos, então, dos dois últimos níveis a que Lihon considera como sendo essenciais ao fenômeno informativo, quais sejam, o prescritivo e o emotivo. A respeito deste primeiro, a ação de um informar se vê orientada pela busca não de um verdadeiro emergente, mas de uma normalização que é sempre condição de um devir ao ato de informar-sobre. No caso do exercício jornalístico, a tentativa de se estabelecer uma normalização se apresenta no fazer discursivo que lhe é próprio, o que, com efeito, é ainda condição ao engendramento de ideologias específicas. Pois ao normalizar seu ethos e sua techné, também o faz quanto à pretensão de uma formulação ideológica que a caracterize enquanto atividade no sentido de se orientar por um princípio particular, operado pela vontade mesma de conduzir a razão ao bem comum pelo entendimento e solidariedade.

O nível que nos resta considerar, partindo de sua aclimatação ao fazer jornalístico, é aquele comumente tido por emotivo, e que, de sua vez, se mostra no modo das formas artísticas. Nesse sentido, é possível inferir que a sensação que temos ao nos deparar com algum tipo de expressão é, a princípio, aquilo que também podemos considerar como sendo informação? Evidentemente que não, porquanto não se trata do modo como nos colocamos diante de uma forma de expressão que se apresenta como sendo um princípio operativo do informar, mas tão somente a maneira como esta se nos vem-de-encontro, enquanto sensível, que de fato o é. Logo, se considerarmos o resultado da atividade jornalística na condição de produto de arte - i.e., enquanto techné -, o que se toma por nível emotivo opera entre a pretensão de impressionar pela ação informativa e a sensação interpretativa que disto se faz. $\mathrm{O}$ 
saber-fazer jornalístico, portanto, tem por finalidade o informar pelo sensível de um impressionar, cuja operação se dá no nível de um emprestar-se-à-emoção.

Há uma especificidade quanto ao modo como, na condição de exercício pelo institucionalizar-de-si, o jornalismo opera esses níveis do pôr-se-a-informar, embora não tenha se apresentado na sequência aqui exposta ou, sobretudo, um por vez conforme o desenvolvimento da atividade no decorrer da história. Cada um desses níveis, alguns antes, outros depois, se interpenetrou a ponto de configurar a noção corrente que temos hoje acerca do modo como opera a informação no jornalismo. Numa espécie de "pré-história" da operação informativa ${ }^{85}$ - correspondente à formação das primeiras sociedades e impérios pelo relacionar humano -, o informar se dava a partir da mesma urgência que serviu de embrião ao jornalismo, qual seja, de se promover a discussão pública donde emergia um opinar-arespeito- $d e^{86}$. Somente muito depois passou a se orientar pelo noticiarismo, i.e., quando do instante em que a ação com fins orientados à informação se legitimou pelo pretender-se do ato mesmo de noticiar, surgido das singularidades de organização das sociedades medievais.

Resta, pois, a seguinte questão: saber se é deste pretender-estar-em-relação enquanto intencionalidade informativa que se mostra a especificidade comunicacional que aqui buscamos. Noutros termos, até que ponto o ato de informar como sendo um levar-adiante pode, dadas as circunstâncias, se alçar à condição de uma relação possível entre sujeitos? Para tanto, será preciso antes observarmos um pouco das singularidades do próprio fenômeno comunicacional enquanto pôr-se-a-relacionar, para enxergarmos os limites do agir informativo quanto à pretensão de um in-comunicar.

\subsubsection{Do Especificamente Comunicacional no Fazer Jornalístico}

Assim como há uma ambiguidade no modo como se nos apresenta o fenômeno informativo, diferente não o é quando se trata de uma essencialidade à comunicação. Se, por um lado, é por vezes considerada tão somente a partir das tecnologias de caráter informativo que a configuram como instrumentum, por outro, se complexifica quando tida enquanto

\footnotetext{
${ }^{85}$ Cf. MONTALBÁN, Vázquez. Inquérito à informação: o fundo do problema da informação. Lisboa, Portugal: Iniciativas Editoriais Lisboa, 1971.

${ }^{86}$ Muito embora não se apresentasse ainda como necessidade de um levar-adiante a ponto de romper-com.
} 
aquilo que é imanente ao ser no sentido de uma razão absoluta a nos orientar. Por conta disso, ela própria na condição de campo acadêmico de produção concernente a um saber específico se vê atravessada por outras áreas do conhecimento humano por não ter força necessária a ponto de sustentar-se enquanto fenômeno fundante do que, sendo, simplesmente somos no modo de tendência que é sempre devir.

Não há consensos ou certezas consistentes para que se tome por definido um objeto de estudo que seja próprio ao comunicar, pondo em jogo então uma tensão ontológica ${ }^{87}$ a lhe acompanhar desde sempre. Pois ora é tido por uma constituição existenciária do ser, ora como estratégia com fins orientados à consecução de algo - e, portanto, de instrumento-a-serviço-de - que não se orienta necessariamente pela ética instituínte de um pôr-se-a-relacionar. Nesse sentido, portanto, não há uma estabilidade fenomenológica quanto a uma noção fundante de comunicação, porquanto ao lançar nela luz sobre quais aspectos e elementos lhe são essenciais, costuma-se fazê-lo a partir de parâmetros que lhe são exteriores, i.e., tendo por base conceitual os saberes doutros campos do conhecimento humano.

Não trataremos aqui das singularidades de uma crise epistemológica no campo da comunicação, porquanto interessa tão somente analisá-la enquanto fenômeno a nos instituir existenciariamente numa dimensionalidade normativa que se dá sempre pelo pôr-se-arelacionar como modo de orientação teleológica. Esse é o modo como, partindo de uma epoché fenomenológica, nos debruçamos sobre ela. Não por ser esta a postura que se mostra mais correta à sua compreensão, mas por nos conceder a pertinência consonante ao problema deste trabalho. Por isso se assumiu desde o início que, excluídos boa parte dos atributos que não lhe são essenciais como princípios operativos, aquilo que resta é, pois, o ser-para-outremque-tem-vontade, i.e., a coisa primeira cujo querer se funda à captura do dis-por que lhe ponha a querer-atender à vontade de estar-em-relação.

Lidamos, portanto, com uma dimensão humana de compreendê-la enquanto fenômeno que está-em-nós-e-para-outrem, muito embora tenhamos desconsiderado outras visadas por não serem pertinentes às reduções eidéticas que até aqui se fez. Mas a relação com o Outro não é operada apenas pelo querer operante de um estar-em-relação, porquanto pode haver nisto um agir estratégico quanto ao fim último nos termos do próprio relacionar. Para que este

\footnotetext{
${ }^{87}$ Cf. NAVARRO, Raúl Fuentes. La produción de sentido sobre la producción social de sentido: hacia la construcción de un marco epistemológico para los estudios de la comunicación. In: VASSALO DE LOPES, Maria Immacolata (Org.). Epistemologia da Comunicação. - São Paulo: Edições Loyola, 2003, p. 15-40.
} 
não se configure tão só enquanto mero instrumento de um fenômeno que é, de saída, ontologicamente afetivo no sentido de nos mover a um querer-estar-para-o-outro, operamos a todo instante em nossas negociações relacionais os princípios atinentes a um agir ético e solidário. É este operar que, por sua vez, impede que a comunicação se configure apenas pelo instrumentalizar-de-si, a ponto de se nos assegurar a vivência comunalizada com base num pôr-se-a-dominar-o-outro.

Reflitemos. Seria possível pensar numa configuração comunicativa para além da noção processual constituída de dois pólos - i.e., emissão e recepção - no modo como opera o jornalismo enquanto atividade de um informar-a-respeito-de? Disto, em que medida a apropriação $^{88}$ do que se mostra como acontecer à nossa sensibilidade pode orientar os mesmos princípios operativos de um agir essencialmente comunicacional nos termos de um estar-para-outrem?

É preciso, para tanto, que nos orientemos à direção oposta da lógica de que há um emitir de sentido a deixar o sujeito, que reifica-se pela linguagem, e, então, alcança o Outro a ponto de se ter nisso um compreender possível. Noutros termos, desconsiderar que há no fundamento do estar-em-comunicação um princípio que se aproxime do meramente processual, por haver nisso uma paralização da dinâmica quando da interposição de uma mediação - como a própria linguagem, por exemplo. Pois o que se faz do ato nada seria senão um tipo de interrupção dos sentidos que já circulam.

Portanto, um medium não é uma extensão possível sua enquanto fenômeno, mas tão somente um tipo especial de configuração que permite a continuidade do simbólico que construímos antes no agir intencional. Se comunicação trata menos de uma coisa em si do que, propriamente, de um acontecer à emergência de ações orientadas teleologicamente ao intencionar de um pôr-se-a-relacionar, o que se vê no medear de aparatos tecnológicos que configuram o fazer jornalístico é tão somente outro tipo especial de apropriação de um acontecimento que lhe é precedente.

Trata-se, então, não de uma sequencialidade enquanto lógica operativa, mas um conjunto de acontecimentos mais ou menos autônomos e organizados segundo uma configuração emergente no mais singular do estar-em-relação. Noutros termos, algo ocorre tão somente quando nós, no intencionar daquilo que se-nos-vem-de-encontro, nos pomos

\footnotetext{
${ }^{88}$ Já como campo estruturado por uma techné.
} 
também ao-encontro-de como modo de preenchimento pelo encontrar-se do in-comunicar. Do mesmo modo como, a apropriação do que já aconteceu por parte da atividade jornalística é também uma relação com tipos outros de acontecimento, no sentido de ela própria se mostrar como possibilidade à formação de um novo acontecer que já nada tenha que ver com aquele de tipo primeiro do qual se apropriou.

Ponderemos a respeito do seguinte: se a noção fenomenológica aqui apresentada enquanto acontecer nada tem que ver com uma operação processual sua, a urgência que serviu como condição à atividade jornalística - quanto ao sequenciar de sentidos construídos no vivido - operou na direção oposta a de um pôr-se-a-comunicar? Acaso não haveria uma especificidade comunicativa no jornalismo justamente por ele próprio, enquanto atividade mesma que se orienta à continuidade daquilo a que já se discutia, ter sido fundado a partir de um estar-em-processo?

Se in-comunicar, enquanto evento performativo como emergência mesma de um ato consciente, é menos uma coisa a dar-se de modo processual do que, propriamente, um acontecer como modo de preenchimento do querer fundante de estar-para-o-outro, em vez então de uma sequencialidade, devemos observá-lo na condição de agir mais ou menos duradouro ou mais ou menos extensivo e que se orienta à construção e circulação de sentidos que sustentam nossa compreensibilidade pelo deixar-se e permanecer-se aberto do ser.

Destaquemos então, em seu aspecto apofântico, as singularidades do acontecer enquanto in-comunicar, no sentido de deixarmos momentaneamente a problemática concernente àquilo que é tido por comunicação para atermos ao quando eventual deste fenômeno, i.e., não ao que é como tal, mas ao quando é por ser ele próprio um agir no mais aparente do sendo desse pôr-se-a-comunicar. Se observamos já parte do que orienta ao mais essente do querer-estar-em-relação-com-e-para, quais as condições a um quando eventual enquanto o se-mostrante do fenômeno comunicacional?

Sendo assim, o que tomamos por acontecer como sendo o mais aparente de um pôr-sea-comunicar enquanto evento nada é senão que o essente mesmo de um agir teleológico orientado à condição maior que se dá nos termos de um estar-para-o-outro. Solidariedade e razão ética são, portanto, primados à abertura do ser como o entender aquilo que se nos vemde-encontro, pois em seu aspecto noemático, o presentar-se é sempre deixar e fazer ver ao querer fundante que se empresta ao ser. Resta, portanto, investigar esse quando eventual na condição de emergência mesma ao in-comunicar a partir de quatro constituições 
existenciárias que lhe são essenciais enquanto tal, quais sejam, as de tempo, ocupação, dizível e ausência.

No que diz respeito ao aspecto existenciário do tempo, é possível observar que há uma temporalidade não no que concerne à duração de nosso pôr-se-a-comunicar, mas a uma dimensão que nos permite o entregar-se ao estar-em-relação como condição de satisfação ao querer puro, i.e., uma instância temporalmente situada que nos serve de momento ao agir pelo intencionar-o-que-vem-de-encontro. Se excluímos aqui a noção de processo como sendo o cerne do que ocorre ao fenômeno comunicacional, por certo uma temporalidade que lhe é própria nada tem que ver com a duração que se faz dos atos mesmos. Tempo, nesse aspecto, é menos a sequencialidade que respeita a uma cronologia - que se principia com aquilo ao qual, num ato comunicativo, enunciamos e fazemos com que o Outro nos perceba enquanto sujeito que fala - do que, propriamente, à criação de um momento singular donde emerge o construir de nossos sentidos no encontrar-se do aberto do ser e que se apresenta sempre enquanto possibilidade num horizonte futuralizado.

Por conta então da criação desse momento que nos é único, um ato comunicativo

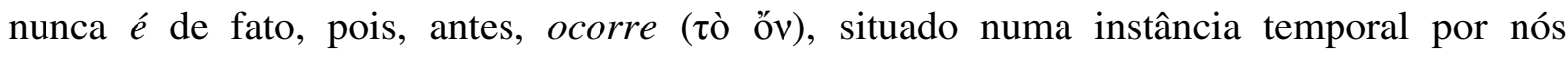
permitida. É como se, a bem da verdade, criássemos nosso próprio tempo quando do instante em que nos emprestamos à captura do dis-positivo que desperta o querer-atender à vontade de estar-para-outro, pois sendo, se difere do tipo de sequencialidade diacrônica do tempo que institui o vivido. Trata-se de uma temporalidade especial que só ocorre quando nos comunicamos, e que, de sua vez, só é tida por comunicação por ocorrer enquanto tal, no âmago de um tempo que nos é próprio enquanto sujeitos que agem orientados por uma relação possível que se funda pelo compreender- $a$.

Para que a temporalidade constituída do momento que criamos pelas ações que nos são comunicativas seja um evento em si, é preciso que, antes, também se crie uma espacialidade específica que a comporte enquanto tal. Um acontecer a partir de uma instância temporal depende, para ocorrer, de um lugar donde sejam partilhados os sentidos construídos pelo estar-em-comunicação. Sem isso, não haveria a possibilidade de fazer com que o resultado desse pôr-se-a-construir-sentidos se realizasse enquanto ato mesmo de intencionar. Mas este lugar, no entanto, não se vê restrito à espacialidade pública ou às instâncias institucionalizadas que se apresentam como locus discursivos, mas, também, aos tipos de lugares criados pelo próprio estar-em-relação, que em si é já um ocupar-se no tempo. 
Percebamos que a noção de ocupar não se refere tão só a um espaço possível à manifestação do relacionar, mas ao tipo de lugar formado pelo intencionar à emergência de um estar-em-relação. Por exemplo, há o lugar donde falamos, que se mostra como espaço de acontecimento a se estender numa temporalidade específica, e há, por conseguinte, o lugar que, desse espaço, se apresenta como instância somente a nós coerente. Ocupar, nesse sentido, é a própria ocorrência singular na instância do partilhar simbólico que nos institui, diferindo do tipo de lugar em que se dá atos outros de comunicação. O que acontece conosco numa situação de relação, se apresenta como um ocupar em dissonância do que emerge noutra também orientada pelo in-comunicar. Não se trata de um espaço já dado no-mundo, mas, no ocupar deste espaço mesmo, aquilo que emerge de singular a ponto de engendrar uma lugaridade nos termos de um partilhar-sentidos pela relação.

Essa noção de lugaridade enquanto ocupar-se no tempo pelo ir-de-encontro pressuposto no pôr-se-a-comungar da relação, pode também ser aclimatado ao tipo de espacialidade engendrado pelo jornalismo. Enquanto espaço institucionalizado, é ele um locus discursivo que regula e controla sentidos pela termitência noética de seu dirigir-se-a. Seu agir último se apresenta como um pretender-se de relação orientado às negociações cujos princípios tendem à ética e ao entendimento possíveis. Mas o ocupar à emergência daquilo a que partilhamos não é um princípio configurativo do jornalismo enquanto campo, i.e., não se vê nele esse tipo de agir por se situar, a priori, num espaço que é em si institucionalizado. Noutros termos, sua estrutura se apresenta menos como lugar de partilha semântica do que um espaço configurador de discursos. Mas enquanto atividade de um pretender-estar-emnegociação, há uma tentativa de instituir com o Outro o tipo de lugar característico de uma relação, a ponto de se criar a instância singular e temporalmente situada donde emerge o semostrante do partilhar.

Reflitemos. Na condição de estrutura estruturante de discursos, o jornalismo nada tem que ver com o tipo de partilha de sentidos característico da lugaridade que também configura o in-comunicar enquanto ocupar-se. Mas, por outro lado, o que se observa é a criação - pela atividade mesma que lhe funda - de lugares que se mostram como condição de possibilidade ao pôr-se-a-negociar pela relação. O que se vê como resultado do exercício é insipiente a ponto de lhe atribuirmos a característica de um ocupar-se no vir-de-encontro do estar-emrelação. Rememorando, portanto, as três instâncias comunicativas do exercício jornalístico, notaremos que o princípio do ocupar-se enquanto o mais aparente do quando eventual se situa 
na primeira e terceira, i.e., da atividade mesma do jornalista ${ }^{89}$ e dos tipos de ocupação no apropriar-se semântico por parte dos sujeitos componentes do público ao qual se dirige o produto do jornalismo.

Aquilo que por hora temos de pôr em relevo diz respeito à segunda instância comunicativa da atividade jornalística, i.e., o momento de negociações entre aqueles que se especializaram segundo as lógicas do campo institucionalizado. Nesse sentido, partindo da premissa de que estas são também tipos outros de estar-em-relação ${ }^{90}$, não seria o caso de isolarmos o resultado aparente da atividade do campo a uma espécie de quarta instância? Observemos o seguinte: as relações no interior do campo jornalístico se apresentam ocultas enquanto tais, pois, a princípio, interessa tão somente o resultado da atividade primeira a partir do ato em si de um informar-a-respeito-de.

Consideremos então como segunda instância esse oculto que não se mostra aparente como um pretender-se-relacionar, sendo a terceira, portanto, aquilo que se dá no mostrar-se seu enquanto atividade pretendida. O problema nisto é que não há uma relação essencialmente comunicativa no presentar-se do exercício jornalístico, posto que falta aí a consistência a ponto de se configurar como lugar de relação. Deste procedimento de isolar o resultado aparente a uma instância outra, temos que a noção de jornalismo não corresponde à especificidade do que lhe funda enquanto princípio a um estar-em-relação.

É possível agora inferir a respeito de dois tipos de jornalismo. Um se apresenta como não-aparente e a operar pelo pôr-se-a-relacionar de uma comunicação orientada ao estarpara-o-outro, em que solidariedade e compreesão são precedências no abrir-se do ser. E o visível como produto acabado, que oculta as singularidades do próprio fazer, mas que, por outro lado, se legitima pela impressão de que há nestas um rigor ético a ponto de se lhe configurar um ethos próprio. Nesse sentido, caso desconsideremos o que emerge como nãoaparente na atividade, o ato em si de um informar-sobre nada seria senão que uma imposição de sentidos prontos que nada têm que ver com uma condição de relações possíveis. Do mesmo modo como, se não atentarmos às possibilidades de um estar-em-relação quando da apropriação desses sentidos, o resultado aparente no enunciar jornalístico seria apenas um discurso termitente à emergência de um verdadeiro pretendido.

\footnotetext{
${ }^{89}$ Que, em princípio, é pretensão de relação enquanto tal.

${ }^{90}$ Diferentes, portanto, daquelas observadas no mundo vivido somente quanto à finalidade, levando-se em conta que a orientação é a mesma, ou seja, trata-se, antes, de um relacionar voltado ao entendimento e à negociação que se pauta por uma ética intrínseca à busca de um verdadeiro emergente.
} 
Deste ocupar-se na lugaridade singular de um acontecer tomado aqui por incomunicar, chegamos à ideia de que, se considerarmos tão somente o jornalismo como o tipo de saber termitente em seu mostrar-se, nada terá ele de especificamente comunicacional. Porquanto toda e qualquer possibilidade de relação apresentar-se-ia improvável diante da discursividade acabada que não se apresenta como acontecimento, mas enquanto um falsear de que aquilo que se enuncia ocorreu junto ao que no vivido aconteceu. Há algo noeticamente singular quanto ao pôr-se-a-informar, que pode, dadas as circunstâncias do próprio acontecer enquanto preenchimento do querer-estar-para-o-outro, ser tido assim como um ver-se-emcomunicação.

Ponhamo-nos então a observar outro dos caracteres existenciários quanto ao pôr-se- $a$ comunicar enquanto acontecer singular, i.e., as especificidades de um dictum na condição mesma de vontade à emergência do intencionar. Noutros termos, tratemos a respeito do conjunto de tudo aquilo a que se enuncia em situações circunscritas numa temporalidade e lugar específicos. O que se diz tem, com efeito, uma substancialidade que lhe é própria por conta da reificação que se faz daquilo que pensamos em dizer, quais sejam, por exemplo, a forma das palavras ou a sonoridade que apresentam. Mas o dizer, enquanto ação mesma, tem já essa característica ontológica que lhe precede, i.e., uma espécie de pré-intencionalidade que se principia no pensar de um dizer até deixar-se capturar pelo dis-positivo da linguagem enquanto condição de satisfação ao querer fundante de dirigir-se-a pelo dizível. Nesse sentido, enquanto não-ação no encontrar-se do entendimento, o propor-se-a-dizer é tão somente pretensão de um estar-em-relação, ou, quando muito, vontade que intenta alçar-se enquanto tal.

Temos de enxergar a singularidade da ação de propor-se-a-dizer enquanto intencionalidade mesma no mostrar-se de dois momentos e espacialidades distintos. De um lado, a consciência na qual se desperta na condição de querer e, de outro, a realidade extraconsciência $^{91}$, donde se apresenta na forma de sons que engendram palavras a partir de codificações sofisticadas. Aclimatando essa lógica ao modo como se configura o jornalismo, é possível compreender que aquilo que se diz à emergência de um estar-em-relação é também atributo eidético ao in-comunicar, até o ponto de, enquanto preenchimento de um querer puro, engendrar os momentos em que emerge o construir dos sentidos nossos. No entanto, não é o dizível em si que se apresenta como relação, mas, antes, a vontade de um querer-

\footnotetext{
${ }^{91}$ Em seu sentido noético de ir-de-encontro- $a$.
} 
relacionar que nos move à formulação de regras e convenções para tal. Noutros termos, a essência do pôr-se-a-relacionar-pelo-dizível nada é senão que um decidir-se no querer estarpara-outrem, e não, propriamente, a forma materializada no mostrar-se do dizer a partir da convenção de símbolos e códigos que pontuam linguisticamente nosso relacionar.

Nos resta agora pôr em relevo esse tipo de configuração quanto à sua pertinência com a instância institucionalizada do fazer jornalístico. Esta, como visto, nada tem que ver com o estar-em-relação no construir dos sentidos pelo intencionar do dizer-sobre, posto que, na condição de saber discursivo, é menos uma deixa simbólica a ponto de fazer com que os sujeitos componentes do público se movam a querer a relação frente ao que é enunciado, do que um dizível termitente e que se esgota em si mesmo. Mas se cairmos na ingenuidade de considerar o se-mostrante do discurso jornalístico tão-só enquanto um enunciar-com-fins-a, não enxergaremos as fissuras contra-discursivas que lhe são próprias, i.e., os espaços e brechas donde os sujeitos, também em situações de fala, argumentam, refutam, concordam, discordam e, disto, constroem sentidos outros que não aqueles primeiramente circulados pela ambiência do jornalismo.

A respeito do que podemos considerar como essencialmente comunicativo na lógica operativa do jornalismo, partindo de uma dimensão normativa concernente a um estar-parao-outro, tem-se que a noção de seu orientar-se ao bem comunalizado pela compreensão em instâncias verdadeiramente dialógicas ${ }^{92}$ é condição de possibilidade ao pôr-se-a-relacionar. Esta, de sua vez, só se mostra enquanto tal por trazer em si o querer fundante que, antes, pôs em movimento o próprio intencionar do pretender-se relacional. Seu fim último quanto à negociação, é sempre telos à emergência do mostrar-se do saber-fazer da profissão, que se apresenta mais como possibilidade de circulação semântica do que, a princípio, de transmissão ${ }^{93}$ enquanto pôr-se-a-informar pela pretensão de que há nisto algo de essencial ao sustento de si na condição de atividade organizada à dinâmica de uma estrutura sistêmica.

Esta que consideramos como sendo a terceira instância da atividade jornalística é, por essência, também um falsear de relação até o ponto de - enquanto termitência discursiva no presentar-se de seu enunciar-sobre - ser incipiente quanto a um estar-em-relação. Por outro lado, é necessário considerar a pontencialidade que apresenta como condição a um relacionar, posto que, da apropriação no espaço do vivido que se faz do dizível institucionalizado, tem-se

\footnotetext{
${ }^{92} \mathrm{E}$ que, portanto, que não falseiam um diálogo possível entre sujeitos, mediado pela ilusão interativa de seus aparatos.

${ }^{93}$ Independentemente da natureza pela qual se mostra o meio.
} 
uma reordenação de sentidos que é possibilidade a momentos outros de um propor-se- $a$ relacionar. Reflitemos. Não se trata aqui daquilo que é dizível pelo jornalismo como discurso institucional com as regras que lhe são próprias, mas, disto, o que é feito com o já dito e de que maneira, a partir de então, se engendram as condições necessárias ao in-comunicar orientado pelo negociar solidário e responsável à emergência da relação.

O dizer no jornalismo é sempre o singular que, em seu se-mostrante enquanto pôr-sea-comungar sentidos, emerge como condição de possibilidade a um relacionar. Importa menos o que é dito do que, propriamente, o intencionar como modo de dirigir-se-a pelo virde-encontro-daquilo-que-se-mostra a ponto de fazer com que, do que se diz, sentidos outros circulem pelo in-comunicar. Por outro lado, o recusar-se do estar-em-comunicação - que é de-cadência ${ }^{94}$ em sua essência - no mais aparente da termitência discursiva em jornalismo não anula ou dificulta quaisquer tipos de relação possível. A fronteira do dizível é, antes, um potencializar de situações donde se tem a possibilidade de pôr-se-a-comunicar, cujo princípio operativo não se inicia pelo ato mesmo de informar-sobre, mas pela pretensão de que, partindo disto, momentos de relação surgirão à dinâmica do estar-em-comunhão.

Compreendidos esses caracteres existenciários do in-comunicar, partamos então àquele concernente ao que se toma aqui por ausência e que também se vê presente no mostrar-se de um estar-já-em-comunicação. Consideremos que, no tipo de ocupar-se que instituímos a partir das circunstâncias situacionais de nosso pôr-se-a-comunicar, haja uma espécie de espaço não visto e, portanto, não manifestado nos momentos dialógicos entre os sujeitos. Noutros termos, neste ideal a que buscamos numa relação enquanto modo de estarpara-o-outro, há tão somente à intersubjetividade intencionada aquilo que, por alguma razão, permaneceu fora do escopo dessa busca. É tudo o mais considerado, nas possibilidades de um in-comunicar, o que se apresenta como silêncio, i.e., as ideias, sentimentos e vontades que de algum modo não se deixaram capturar por uma reificação pela linguagem.

Entende-se que o pôr-se-a-comunicar opera aquém do visível emergente do estar-emrelação, sendo a não-manifestação de um aspecto ou outro o tipo singular de sentido a construir-se, muito embora ausente quanto ao emprestar-se à circularidade. Seria, então, suficiente a ponto de ser considerado essencialmente comunicativo? Sim e não. E a noção de circulação uma vez mais nos será cara deste ponto em diante. Em primeiro lugar, retomemos a

\footnotetext{
${ }^{94}$ Cf. $\S 1$, p. 24.
} 
ideia de que nossas primeiras organizações humanas, enquanto um estar-em-socialidade pelo deixar a condição de ser vivente ${ }^{95}$, foi, a princípio, também de natureza não-linguística. Nestes termos, a própria celebração do contrato tinha algo de silencioso em seu operar, pois as convenções que realizamos no orientar-se negociativo do in-comunicar contemplavam também o não-dizível naquilo que enunciávamos, i.e., tudo o mais que, enquanto ideia e querer fundante, presentava-se de modo não-presentável na forma como as reificávamos.

Não há garantia alguma de que, no reificar, a totalidade de nossos pensamentos assumirá uma forma compreensível a partir do pôr-se-a-comunicar. A própria noção de negociação é uma espécie de estar-em-jogo em que se tensiona, maximiza e minimiza objetivos no intento de se alcançar um telos. O aparente manifestável em nossas relações dialógicas pode, por certo, ocultar um aspecto ou outro do que pensamos, sentimos ou queremos, posto que, partindo da premissa de que negociar é também desistir de algumas intencionalidades em benefício doutras, é o silêncio uma espécie de elemento que se imiscui ao pretender-se do in-comunicar. Mas ele próprio, enquanto não-aparência no intencionar, não deve ser de todo considerado como essencialmente comunicativo, pois se o aspecto mais noemático não for, a fortiori, percebido por outro sujeito pelo mostrar-se da intencionalidade mesma, evidentemente permaneceu de fora no estar-em-relação.

Mas enquanto possibilidade ao propor-se-negociar, o fim último de seu mostrar-se é já um estar-em-relação-com-outrem. Noutros termos, muito embora não se tenha a percepção de que algo se nos é ocultado numa situação relacional dialógica, o silêncio em nosso querer fundante e não visível no dirigir-se- $a$ engendra a própria relação até o ponto de, tomando-o também enquanto constitutição do que nos põe a negociar, compor os sentidos que de sua vez nos orientarão ao mais teleológico do acordar-se-com.

Se o não-dito pode - por ser ele próprio uma ação de silenciar - se apresentar enquanto intencionalidade numa ação outra que é, portanto, comunicativa, a questão que se coloca é: em que medida o silêncio é para o jornalismo o que o é à comunicação? Noutros termos, até que ponto um silenciar-no-presentável-que-se-oculta pode, dadas as circunstâncias, ser um se-mostrante enquanto princípio configurativo da atividade jornalística? Há, no pretender-informar, uma configuração que se dá em dois momentos ou dimensões distintas: o instante em que se diz algo pela impressão de que há nisto a totalidade

${ }^{95}$ Cf. $\S 2$, p. 44 e segs. 
de uma busca por um verdadeiro, e, por sua vez, o momento em que, deste intencionar, também se soma outro que se principiou por um tipo de negociação operada pelo ocultar.

Se nos atermos tão só à instância do dizível institucionalizado, veremos que o modo pelo qual também se configura o pretender-se do informar no jornalismo é uma espécie de querer-des-ocultar-ocultando, até o ponto de haver sempre um conjunto ${ }^{96}$ de elementos a permanecer ausente em seu discurso. Pelo negociar enquanto modo de in-comunicar, configura-se a ausência no mostrar-se-continente daquilo que é posto ao silenciar do estarem-relação-para-o-outro. O discurso jornalístico, em seu intencionar como forma de pretender-informar a partir do deixar-transparecer de um rigor ético quanto à busca do verdadeiro no vivido, de fato se mostra como um dizer termitente. Mas o propor-se-anegociar que lhe é próprio apresenta-se, antes, no operar de pausas, diálogos e silêncios comuns a quaisquer formas de negociação. Reflitemos:

\begin{abstract}
no discurso midiático, os silêncios são insuportáveis e intoleráveis, uma vez que assinalam a perda da relação com o público e são, por conseguinte, encarados como um risco letal para o próprio funcionamento do seu dispositivo de enunciação. Falar, falar sempre, mesmo que seja para não dizer nada; [...]. É por isso que uma das funções comunicacionais mais importantes do discurso midiático, além da função referencial, que consiste em dar conta dos acontecimentos que ocorrem no mundo, é a função fática, que consiste na manutenção do contato com o público. (RODRIGUES, 2002, p. 218 - Grifo nosso).
\end{abstract}

No que concerne à intencionalidade do pretender-informar em jornalismo, nada mais evidente que sua operação consista em passar a impressão de que há algo acabado no que se enuncia a ponto de funcionar sem intermitência alguma, como se o tipo de saber engendrado pelo ato mesmo de um informar-a-respeito-de, fosse já o que se toma por verdade. Mas toda ela se configura, em princípio, por interrupções e tensionamentos relacionais quanto ao pôrse-a-comunicar nos silêncios desse estar-já-em-relação. Há, portanto, dois momentos neste in-comunicar: o negociar dos sentidos tanto na instância do vivido, como nas de ordenação no pretender-se do informar-sobre e o instante em que operamos uma con-vivência nos termos de um estar-em-pacificidade.

Essa noção de con-vivência é cara ao que aqui tomamos por comunicar enquanto intencionalidade orientada ao telos de um propor-se-a-construir sentidos. Esse princípio em nada difere do deixar-se-capturar como modo de estar-para-o-outro, que nos pôs a organizar

\footnotetext{
${ }^{96} \mathrm{E}$ que, portanto, é este o que se toma aqui por não-dizível ou não-manifestado.
} 
as primeiras sociedades humanas. O preenchimento do querer puro quanto ao dirigir-seàquele-que-nos-vem-de-encontro foi também uma urgência à necessidade de conviver-junto$a$, como forma de nos guiar à pacificidade e ao fim de toda barbárie pela ignorância ${ }^{97}$. Deste modo nos despertamos a querer partilhar aquilo que nos constitui existenciariamente, i.e., toda e qualquer vontade de ver-se-junto-a-outrem.

Do con-viver enquanto fim último ao estar-em-comunicação, podemos também compreender que, na configuração de um jornalismo cuja atividade se apresenta mesmo hoje pela urgência no desafiar a $\operatorname{algo}{ }^{98}$, seu agir na condição de pretender-se- $a$ pode direcionar à pacificidade. Se, de um lado, temos uma intencionalidade concernente a um ordenar-peloinformar, por outro, há a finalidade de manter uma con-vivência possível entre os sujeitos que se situam aquém e além daquilo que se mostra como aparente no enunciar termitente do jornalismo. O especificamente comunicacional nisto, portanto, vê-se à emergência noética do intencionar como manutenção ao querer-conviver. O que o conjunto de ações no jornalismo opera, antes de se limitar à mera ordenação do que se encontra já aí no mundo, nada é senão que este deixar-se-emprestar à vontade mesma de um conviver-com-e-para, até o ponto de fazer circular sentidos outros que já nada têm que ver com o que se discursa no campo jornalístico.

A dinâmica mecanicista de ordenar o vivido a ponto de transformar o resultado deste pôr-se-a-organizar em produto que se lhe regressará uma vez mais é, com efeito, parte disto a que tomamos por ciclo tautológico do jornalismo. Mas, considerando que sua techné não se limita tão só a esse proceder-de-si-para-si, é preciso pôr em claro aquilo que lhe constitui enquanto essência, visto que o ato mesmo de um informar-a-respeito-de não lhe é único enquanto atributo fundante.

Lidamos agora com uma noção de jornalismo cujo operar tem no configurar-de-si a condição de orientação à con-vivência que se sustenta pelo telos que é sempre devir em sua futuralidade. Tratemos, pois, de uma urgência outra que não aquela que serviu de embrião à sua atividade, ou tampouco à que se lhe mostrou como pretender-se-sustentar, mas, uma que é razão primeira da essencialidade mesma em seu se-mostrante. A ordenação do mundo como modo de intencionar a partir do informar-sobre é pretensão que, no pretender-se- $a$, se mostra

\footnotetext{
${ }^{97}$ Embora permanecesse esta, como se vê hoje, enquanto pretensão de fins meramente estratégicos.

${ }^{98}$ Que é, neste caso, informar para ordenar e dar sentido a um mundo aprioristicamente caótico do ponto de vista de uma organização coerente.
} 
enquanto con-viver nos termos de um estar-já-de-saída-para-outrem. Ainda que a techné jornalística sirva de instrumentum aos processos mecanicistas que dão forma a seu produto ${ }^{99}$, é possível observar uma teleologia do exercício no que diz respeito ao negociar de sentidos no pôr-se-a-relacionar que é sempre comunicacional. Há nisto uma tríplice configuração, que concerne àquilo que se enuncia, o que é informado partindo deste enunciar como modo de irao-encontro-de e o que é compreendido pelo apropriar que se faz quanto ao dirigir-se-para-oque-está-aí-no-encontro.

O que se enuncia e, sobretudo, o modo como esta enunciação se dá, não emerge à estrutura institucionalizada do jornalismo como um saber finalizado em si, ainda que se configure pela impressão mesma de uma termitência discursiva. Para que se engendre as condições a um dizer-sobre no mostrar-se de uma não-termitência, é necessário que o dirigirse- $a$ enquanto apropriação do vivido se dê nos termos de um mover-se-à-relação no con-viver essencialmente teleológico.

Pode o jornalismo então operar somente a partir de um pretender-informar que é intencionalidade no des-velar que oculta? Mais até: se informação é, como visto até aqui, potencialidade que conduz a relações e não, propriamente, a relação em si, em que medida a essencialidade comunicativa que lhe é própria no sentido de nos mover a uma convivência possível é suficiente a ponto de assegurar a pacificidade em nosso viver?

O reconhecimento daquilo que se enuncia pela atividade jornalística é operado quando do instante de sua apropriação pelos sujeitos componentes do público aos quais se destina o escopo de todo exercício. O que assegura essa apropriação é a partilha de uma linguagem a todos comum e que, ela própria, se apresente pela convenção a que se chegou no sentido de fazer com que o dizível que emerge de seu saber-fazer assuma a compreensão como sendo um todo significativo aos que se põem no estar do comunicar.

Noutros termos, a pretensão de ordenação do mundo só foi possível por haver já um aspecto ordenador na linguagem, que serviu de suporte ao ato mesmo de um informar-arespeito-de, porquanto é também atributo ao exercer da profissão. Ocorre que, por ser uma atividade no operar de um dizer, o intencionar enquanto pretender-informar não pode se alçar à condição de extra-linguística, a menos que algo naquilo a que se enuncia, de algum modo, se oriente à dominação. Mas aí, teríamos qualquer outro tipo de intencionalidade que não a

\footnotetext{
${ }^{99}$ Que é sempre fim último no mais aparente e superficial de seu mostrar-se.
} 
informativa, porquanto esta última, ao menos no dizível do jornalismo, não é suficiente a ponto de algo nesse sentido.

Se observarmos a lógica operativa desse exercício tão somente com vistas a essa única instância, cairíamos na ingenuidade de considerar que não há nada além da instrumentalização em sua intencionalidade. Ou, noutros termos, que o escopo da techné jornalística guia à contramão de uma ação que se pode considerar como sendo comunicativa. A bem da verdade, a articulação da instância discursiva do jornalismo nada é senão que uma organização particular que emergiu de relações e negociações que se apresentaram antes como essencialmente comunicacionais. Não esqueçamos, pois, a instância última donde se apropriam os sentidos engendrados pela ação discursiva da profissão e, disto, à circularidade de produções semânticas outras.

$\mathrm{O}$ limite em considerarmos o pretender-se do informar-a-respeito-de enquanto intencionalidade comunicativa também se dá no sentido de que as instâncias se juntam até compor um todo significativo que dá sentido a um con-viver possível. Por exemplo, na instância primeira da atividade, a relação com o Outro é condição sine qua non à apropriação de sentidos daquilo que emerge do vivido, e que, nesses termos, o que se enuncia na estrutura do campo é menos uma continuidade do que se apropriou, do que complemento do já semanticamente engendrado. Do mesmo modo, quando da apropriação do resultado de toda intencionalidade informativa pelo discurso jornalístico, os sentidos outros que emergem ocorrem em concomitância ao instante de sua percepção pelos sujeitos componentes do público, i.e., a partir do momento em que, na condição de produto, aquilo que se informa passa a assumir uma dimensão diferente do que até então se tinha.

Nesse sentido, se isolarmos o momento do ato mesmo de informar, nada nos restaria a ponto de inferir que há nele algo de especificamente comunicacional, muito embora, enquanto configuração, em instância alguma tenha se apresentado como sendo isolado. Por isso é preciso pensar a lógica configurativa da atividade jornalística como um ciclo complexo e ininterrupto de articulação de sentidos vários, até o ponto de, dessa dinâmica, emergir as condições de possibilidade a um con-viver pacífico e orientado sempre ao telos.

O tipo de pôr-se-a-relacionar enquanto condição à construção de sentidos não emerge, necessariamente, do ato mesmo de informar-sobre. Noutros termos, ainda que a informação jornalística se apresente como condição a relações ulteriores, é falso inferir que estas surgem tão somente por ter havido antes a pretensão de querer-informar. A chave para compreensão 
do modo como nos relacionamos quando da operação do exercício jornalístico é menos o tipo de apropriação que fazemos do ato informativo do que, especificamente, o modo singular como a informação nos vem-de-encontro. Antes da própria codição de sujeitos, pretendíamos já atribuir sentidos às coisas. Partindo dessa perspectiva, nossa relação não se dá especificamente com a informação do jornalismo, mas com o mundo possível que foi antes formado a ponto de assegurar a própria intencionalidade do informar.

Não é a informação, portanto, que nos orienta à convivência, mas o mundo coerente que a ela se associa no sentido de, por ser ele próprio instituído a partir de relações negociativas, se apresentar enquanto articulador de quaisquer relações que venhamos a ter na circummundaneidade. Somente na relação com este mundo que se nos apresenta enquanto tal, movemos os sentidos a ponto de reforçar os laços de comunicação que nos fundam na condição de sujeitos, o que faz do ato mesmo de um informar não o atributo essencial de uma intencionalidade comunicativa, mas uma espécie de articulação que potencializa o que pode emergir de nossas relações a ponto de ser considerado como comunicação. Movemos sentidos quando do pôr-se-a-comungar com o mundo possível e coerente do jornalismo, que de sua vez, é também instituído a partir de mundos outros a trazerem sua própria singularidade semântica. O que se toma por informação, enquanto ação de termitência discursiva é parte de sua configuração, embora, em essência, não seja esta um comunicar.

Sendo assim, não se trata tão somente de inferir que o informar-a-respeito-de seja comunicativo por se apresentar como condição de possibilidade a uma relação, mas, antes, de compreender que ele próprio, enquanto tal, emergiu de uma convivência alcançada pelo pôrse-já-a-comunicar. Isso faz do ato informativo uma configuração essencialmente relacional? Não exatamente, porquanto não há garantias de que relações outras sejam potencializadas tãosó pela pretensão de informar com fins orientados à convivência. O que se pode questionar, por outro lado, é em que medida a atividade jornalística faz dessa intencionalidade informativa uma pretensão de mover os sujeitos que se situam aquém e além de sua estrutura de campo a um querer-relacionar-com.

Tem-se claramente uma finalidade decorrente do exercício jornalístico a partir de um informar-a-respeito-de, qual seja, a de ordenar o mundo que se nos apresenta enquanto caótico. Como visto aqui, essa organização a partir de um todo que nos fosse simbolicamente coerente se apresentou como urgência de dar sentido ao mundo e, com efeito, como desafio à estruturação de toda a atividade a partir de uma ambiência que lhe fosse própria. Pois foi 
preciso alçar-se como um campo que lhe justificasse o saber-fazer e que se diferenciasse da techné doutras áreas de conhecimento. Em princípio, a necessidade de uma ordenação tinha que ver com o asseguramento de uma convivência possível, até o ponto de, por ela própria se mostrar enquanto dispositivo, nos mover ao querer desta convivência. Mas, por outro lado, ao transformar a intencionalidade informativa num produto cujo intento se dirige ao sustento de si, a dinâmica que lhe é própria já nada então tem que ver com a pretensão de uma relação que se orienta à con-vivência.

Mas, se o exercício jornalístico se orienta hoje pela capacidade estocástica de conteúdos simbólicos que emergiram antes da espacialidade do vivido, a pretensão de uma convivência possível a partir das relações é tão somente uma consequência que lhe foge do propósito? O problema, por certo, está associado à noção de mensagem em jornalismo, i.e., os tipos de "produtos de comportamentos relacionados com os estados internos das pessoas"100. Estes conferem ao ethos do jornalismo uma pretensão outra que se apresenta no sentido de serem seus profissionais os mensageiros que ordenam o mundo com a techné que lhes é própria. Disto, tem-se também a falsa impressão de que o escopo da atividade se configura pelo transporte de um saber àqueles que, em princípio, não o detém. Falso, pois, enquanto simbólico operando a partir de uma mediação específica, não há essa espécie de saber pronto transmissível, mas a disponibilização de um saber de fundo que é desenvolvido sobretudo para além da instância donde se situa o pretender do pôr-se-a-informar.

Se o intencionar do pretender-informar-sobre não se mostra, em jornalismo, como mera mensagem ordenadora de saberes transmissíveis, não há então como desconsiderar a dimensionalidade normativa que também lhe funda enquanto ato, i.e., enxergá-la como condição de possibilidade a convivências emergentes de negociações nas relações comunicativas. Reflitemos:

a informação é um veículo de conhecimento e conhecimentos. Para o homem da rua converte-se em sabedoria e interpretação do mundo e dos homens que o rodeiam. Esta sabedoria e interpretação forjam uma opinião e, dado o caráter comunal dos meios informativos, forjam uma opinião pública, apoiada numa ideologia colectiva. (MONTALBÁN, 1971, p. 220).

Esta noção de veicular é pertinente com o que até aqui se discutiu, visto ser um guiarà-frente de sentidos que não foram aprioristicamente engendrados pelo campo jornalístico,

${ }^{100}$ Cf. BERLO, David, O processo da comunicação: introdução à teoria e à prática. SP, Martins Fontes, 1999, p. 167. 
mas que emergiram do vivido a ponto de, na própria estrutura institucionalizada, ganharem nuanças e pretensões outras que não aquelas primeiras. $\mathrm{O}$ intencionar enquanto pretender-seinformativo como mera transmissão de mensagens de um estado a outro de percepção é tão somente atribuir ao próprio ato uma causalidade específica que pode não ser atributo de uma essência sua. Noutros termos, se o ato em si de informar fosse ao jornalismo apenas um proceder orientado à ação e reação frente ao que se enuncia informativamente, não haveria relação possível nesta dinâmica que se configura de modo sumariamente mecânico.

Mas, por outro lado, não se pode deixar de considerar que exista a princípio um tipo singular de reação por parte dos sujeitos componentes do público ao qual se destina a atividade jornalística, qual seja, a que move a vontade de contar a outrem o que se informou. Percebam, então, que reação aqui nada tem que ver com a causalidade iniciada pela transmissão a ponto de se apresentar como resposta ao ato mesmo de informar, mas a possibilidade de se deixar capturar pelo dispositivo que nos move a querer atender à vontade de um contar-a-respeito-de. Reação é, portanto, um deixar e fazer ver singular de um querer que se mostra como potencialmente relacional.

Da urgência de ato que se configura pelo ordenar, a intencionalidade informativa que se apresenta na ação mesma de um noticiar-sobre é também condição de possibilidade à articulação do dis-positivo que nos move a querer principiar uma relação partindo do já enunciado pelo discurso jornalístico. Noutros termos, somado ao conjunto de suas operações, o ato de informar é, do mesmo modo como uma ação essencialmente comunicativa, um tipo singular de estar-em-negociação pelo comungar de sentidos à emergência do já informado. É preciso então compreeder que, para além da atribuição de um aspecto que lhe seja normativo, o informar não teria condições de se configurar como tal se, disto, fossem excluídas ou desconsideradas as negociações comunicativas que pontuam a própria pretensão que antecede a ação informativa com a qual opera a atividade jornalística.

Haveria limites quanto à exclusão de uma normatividade da informação mesmo se, a princípio, considerássemos tão somente um de seus atributos concernentes à ideia de dado. Nesse sentido, ainda que opere como mensagem epistemicamente objetiva, o próprio modo como se configura enquanto tal é decorrência de um agir humano no sentido de que não foram as máquinas as responsáveis pela própria configuração que apresentam. Temos, assim, uma premissa básica: independentemente do modo como se apresenta no mundo, informar é uma ação que nos movimenta a algo. E na ambiência do jornalismo, esta lógica operativa não se 
mostra de modo contrário, uma vez que a informação não nos chega necessariamente na forma de simples mensagem a ser decodificada por um repertório cultural e simbólico que nos é prévio, mas também como possibilidade a um pôr-à-frente aquilo que move uma comunicação possível.

Evidentemente, tratamos aqui de um tipo singular de potencialidade que se apresenta como atributo essencial à ação de informar, conquanto se oriente esta pela con-vivência. Por isso, não podemos inferir de antemão que seja o pretender-se informartivo enquanto intencionalidade um tipo de estar-em-comunicação. Mas na condição daquilo que nos dispõe- $a$, por outro lado, é ela parte da essência que nos institui enquanto seres de comunicação, até o ponto de despertar o querer-relacionar. No entanto, não basta tratarmos de uma condição de possibilidade se, a princípio, o resultado da atividade jornalística em nada se propõe a este querer mesmo, posto que a necessidade de uma ordenação ainda lhe é cara àquilo que lhe sustenta o saber-fazer. Enquanto proposta percebida por outros, fica tão somente visível a urgência de um falar-sobre, que é operado pela ação de informar, não ficando exposto como pretensão à urgência de nos mover a uma relação até o ponto de pacificar o con-viver.

É preciso salientar a ideia de que os tipos de relações surgidos da potencialidade do ato mesmo de informar-sobre não se apresentam como consequência emergente dessa configuração tratada acima, pois lidamos aqui com uma complementaridade a pontuar toda a dinâmica. Sendo assim, a circulação de sentidos pela relação não é consequência imediata do ato em si de informar, mas tão somente a condição de que, uma vez noticiada as dimensões de um acontecimento no vivido, relações de tipo outro serão engendradas. Entedemos aqui esse "tipo outro" como sendo toda relação negociativa que não emerge necessariamente daquela entre sujeito jornalista e não-jornalista, i.e., por não haver de fato uma efetividade relacional na própria mediação dos aparatos que materializam o produto jornalístico, o conteúdo por sua vez noticiado se apresenta como pretexto à discussão. A não ser, evidentemente, que se estabeleça, de algum modo, o contato possível entre ambos e a operar em tautócrono no que diz respeito à produção semântica. Com isso, há por certo uma manutenção daquele princípio operativo que serviu de embrião ao exercício jornalístico, mesmo antes de este se institucionalizar como estrutura sistêmica.

$\mathrm{O}$ acontecer no jornalismo não se mostra como ordenação, mas como aquilo que emerge de um inesperado até então não possível. Noutros termos, a intencionalidade no 
noticiar-sobre se apresenta na forma de um produto cuja razão mesma de ser se justifica pela imprevisibilidade do que ainda não é. É como se, a ação de noticiar pelo princípio operativo da informação operasse apenas no sentido de presentar-se como um inesperado aos sujeitos componentes do público, que, de sua vez, interpretam já a informação como um tipo singular de imprevisibilidade emergente do vivido. Nesse caso a intencionalidade do pôr-se-ainformar é também uma espécie de acordo tácito entre os sujeitos que se situam aquém e além da estrutura do campo jornalístico, a ponto de se verem nas condições adequadas a uma negociação dos sentidos que surgem disto.

Se, portanto, algo no jornalismo só acontece por haver, antes, essa espécie de acordo de que, para ocorrer, deve ele se apresentar como um inesperado daquilo que emerge do vivido, por certo a ação de informar é também uma pretensão de impor uma estrutura àquilo que acontece ${ }^{101}$. A bem da verdade, a própria intencionalidade noticiosa é já um tipo singular de tentativa no sentido de se estruturar ordenativamente um evento ocorrido. O problema nisto, é acreditar na impressão de que algo aconteceu tão somente por ter se mostrado notório à ação de informar a seu respeito, i.e., de que a busca por um verdadeiro no vivido resultou numa verdade em si mesma que só é enquanto tal por intentar a impressão de que foi o discurso jornalístico a partir do ato de noticiar que assegurou o que a princípio se toma por acontecimento. Falso, porquanto o princípio adotado pela deontologia jornalística no sentido de dar notoriedade a um acontecimento é o da relevância e pertinência aos tipos de postura que os profissionais de seu campo adotam como ethos e não, propriamente, o de que há nesse tornar-visível pelo discurso uma noção de verdade simplesmente por se mostrar como acontecimento noticiado.

A ordenação que se faz então pela impredictibilidade ${ }^{102}$ só se apresenta como condição de possibilidade à negociação de sentidos por ser, ela própria, uma aceitação a priori de que aquilo a que se noticia é um produto enquanto tal. Disto, o que se tem é uma dinâmica concernente à ação de informar a partir de repetições e renovações do conteúdo enunciado e que, de sua vez, se apresenta como potencializadora de relações vindouras quando da complementaridade semântica por parte dos sujeitos componentes do público ao qual este produto se destina.

\footnotetext{
${ }^{101}$ Cf. PHILLIPS, Barbara. Novidade sem mudança. In: TRAQUINA, Nelson. Jornalismo: questões, teorias e 'estórias'. 2. ed. - Lisboa: Vega, 1999, p. 327.

${ }^{102}$ A partir do princípio de que há entre os sujeitos jornalistas e não-jornalistas uma espécie de acordo tácito em torno do que acontece.
} 
Temos, portanto, um modo outro de encarar o princípio de predictibilidade do ato mesmo de noticiar-a-respeito-de: o de compreender que a termitência discursiva do jornalismo é menos o novo emergente da busca de um verdadeiro que se apresenta enquanto evento não-esperado, do que uma regularidade na própria intencionalidade enunciativa de acontecimentos que se configura pela adequação destes à estrutura previamente estabelecida de um narrar. Noutros termos, o que se informa pela discursividade jornalística não é necessariamente a emergência de um novo surgido da espacialidade do vivido, mas um destacar-do-que-está-aí pela impressão de que há nisto uma relevância a ponto de ser noticiada a partir da visibilidade assegurada pelo campo.

Não é a obrigatoriedade de um aspecto não esperado que conduz o modo como opera a atividade jornalística, mas, antes, o tipo de regularidade habitual engendrado pelas regras concernentes à estrutura sua de campo que faz emergir uma noção mesma de obrigatoriedade enunciativa. Por exemplo, não se tinha antes da estruturação das deontologias jornalísticas a urgência de se evidenciar pelo pretender-informar o inesperado, porquanto a própria continuidade em plataformas midiais daquilo a que se discutia nos espaços públicos era já o novo enquanto se-mostrante. Foi, portanto, a partir de uma sofisticação da techné jornalística que moldou-se a curva de regularidade enunciativa que conduziu àquela urgência de informar tão somente o que se mostrava imprevisível à realidade vivida, e não, propriamente, o que era conjuntural ao bem comum.

Desta urgência então de se noticiar tudo o mais que se apresentava enquanto nãoesperado no vivido, um aspecto singular na própria configuração do saber-fazer jornalístico passou a assumir outra dimensão, qual seja, o fato que servia de articulação à intencionalidade informativa. A questão que se coloca nos conduz ao seguinte: em que medida aquilo que se toma por fato é condição de possibilidade ao ato mesmo de falar-sobre no campo jornalístico? E nesse sentido, a partir de qual princípio operativo a ação de enunciar no jornalismo assegura a continuidade que lhe é própria? É preciso, para tanto, que tudo aquilo tido por fato no jornalismo seja epistemologicamente orientado no sentido de partir dele próprio a impressão que se tem de uma verdade mesma.

Se não há uma existência em si concernente aos fatos, evidentemente também eles precisam de um tipo especial de ordenação a ponto de se adequarem à proposta do jornalismo, i.e., têm antes de se apresentar como condição de possibilidade ao ato mesmo de noticiarsobre a partir de um princípio que opere no sentido de uma organização coerente. Este, por 
sua vez, não é outro senão a própria observação que se faz daquilo que acontece na espacialidade do vivido. Há, deste modo, que se considerar o seguinte: se o observar dos eventos no mundo circundante se mostra enquanto princípio operativo que condiciona um fato específico às curvas regulares de toda intencionalidade de noticiar, a partir do que, propriamente, se orienta a ação mesma de uma observação? Temos antes de considerar, à luz do que até aqui foi exposto, que o modo como a ação noticiosa se nos apresenta é parte de uma espécie de esquema coeso que também orienta o tipo de percepção e compreensão que fazemos frente à ação de informar. Estes esquemas são o que constitui a própria configuração do modo como se enuncia no jornalismo, como os tipos de ordenações lógicas e princípios operativos que asseguram a ação de um falar-sobre.

Coloquemo-nos nessa linha de reflexão: se são os esquemas da própria lógica configurativa do jornalismo que asseguram a consistência de uma intencionalidade informativa que lhe é cara, evidentemente a orientação que se faz a partir de uma observação é também uma espécie de olhar interrogativo do mundo sem o qual o próprio exercício da profissão ver-se-ia fadado a um palpitar-acerca-de. Lidamos agora com um tipo outro de impressão que se acrescenta ao ethos do jornalista, qual seja, a de que um olhar seu que se projeta à luz do mundo é, antes, uma ação orientada pela legitimidade do saber-fazer decorrente da especialização concedida pelas instituições que lhe são concernentes. Olhar, em jornalismo, é o princípio operativo que movimenta a ação de informar, sem o qual a busca por uma episteme seria tão somente mera impressão das coisas mesmas.

É também no olhar, portanto, que a própria regularidade de um não-esperado se confirma pela atividade jornalística, até o ponto de fazer emergir a impressão de que uma verdade mesma das coisas se apresentou pelo pretender-se-informativo. Ocorre que, por se situar numa ambiência orientada pela constante legitimação que se faz acerca de todo tipo de intencionalidade, é também o olhar uma espécie de saber gnóstico que, de sua vez, se vê ausente nos não especializados. Nesse sentido, do mesmo modo como o narrar pela informação se apresenta na condição de um tipo singular de controle e poder operados à estrutura sistêmico-institucionalizada do jornalismo, o olhar especializado é já um asseguramento de que a busca por uma verdade emergente se orientou pela impressão de uma infalibilidade do jornalista que observa.

O que se tem, então, é uma analítica do ato em si de olhar-para, que, no caso dos profissionais que se situam no campo jornalístico, é toda ela epistemicamente orientada, no 
sentido de que a compreensão dos eventos no mundo se dê não pela impressão perceptiva que destes se faz, mas antes, pela compreensão dos acontecimentos no modo como estes se nos apresentam, como modo singular de intuir ${ }^{103}$. Noutros termos, portanto, não basta ao jornalismo ter por princípio operativo à intencionalidade de informar tão somente o olhar que se projeta ao mundo, porquanto, mais importante, é a capacidade de fazer desta ação uma análise que é própria à lógica operativa do campo e que guie ao entendimento daquilo a que acontece.

Mas há, nessa noção de olhar epistemicamente orientado, um tipo outro de intencionalidade que não emerge de modo explícito na atividade jornalística, i.e., um controle com o qual se exerce a própria ação de observar-para. Noutros termos, criou-se a impressão de que a especialização de um olhar atinente ao exercício do jornalismo é o ideal ou mais correto a ponto de fazer com que uma verdade mesma das coisas guie ao bem comunalizado a partir do ato em si de informar.

Dessas espacialidades em específico ${ }^{104}$, tem-se o reconhecimento imediato e assegurado daquilo que, antes, se observou na ambiência do vivido. E garanti-lo, é parte do escopo do exercício jornalístico no intencionar de seu informar-a-respeito-de, para que disto os próprios dispositivos que lhe são concernentes operem a ponto de preparar os sentidos de um relacionar possível. Evidentemente, a intencionalidade de um olhar-para não é em si comunicativa, porquanto, ao menos no jornalismo, é ação que se dá de modo instrumental no sentido de legitimar a especialização que se fez em torno do ato mesmo de observar. O tipo de relação que emerge desta dinâmica é tão somente aquele que compete ao sujeito observador e ao objeto observado, não havendo, portanto, uma circularidade semântica do ponto de vista comunicacional. Por outro lado, na ausência de um olhar epistemicamente orientado e com fins a esse controle do que se observa naquilo a que acontece, a própria preparação aos sentidos não seria possível, a menos que se intentasse um modo outro de capturar os sujeitos não-jornalistas a uma convivência pelo negociar que se faz em torno destes.

Na medida do olhar, há também aquilo que oculta a busca pelo verdadeiro emergente, i.e., pela observação, o jornalismo opera no sentido de ocultar as singularidades daquilo que lhe configura enquanto atividade, até o ponto de se apresentar tão-só como um saber

\footnotetext{
${ }^{103}$ Aqui, diferenciamos ontologicamente aquilo que é percepção e o que é intuição. Enquanto esta primeira trata de um dirigir-se noematicamente ao que se nos vem de encontro, o segundo, de sua vez, concerne àquilo que, no encontro, é já condição à empatia e ao des-velar das coisas mesmas.

${ }^{104} \mathrm{Cf}$, e.g., as páginas de um jornal ou mesmo aquilo a que se noticia noutra plataforma midial do jornalismo.
} 
termitente que se deu por um olhar não questionado. O problema nessa dinâmica não é a ausência de um des-ocultar pelo exercício, mas crer que, de sua vez, aquilo a que se oculta é uma ação única no sentido de intencionar a busca por uma verdade mesma a partir da informação. É como se, pelo ocultar, também se intentasse a impressão de que não há uma instância outra dotada de mesma habilidade a ponto de informar acerca de algo. Noutros termos, passa-se a impressão de que nenhuma outra atividade vinda de quaisquer esferas se veja suficientemente apta a ponto de informar a partir de um olhar especializado sobre o vivido, quando, na realidade, instituições diferentes fazem já o mesmo.

O que difere então o tipo de pretender-se-informativo enquanto intencionalidade mesma no jornalismo do de outras instituições é tão somente o modo como esta, enquanto ação consciente, se volta ao pôr-se-em-relação. Do contrário, sem a pretensão de formar as condições de uma ação comunicativa, o profissional do campo seria nada além de um selecionador ao acaso cujo esforço se volta à ordenação hierárquica e mecanicista de eventos e seus respectivos aspectos.

Mas não há, por sua vez, um princípio normalizador que oriente o jornalista a ponto de suas intencionalidades se direcionarem a uma complementaridade semântica por parte da pessoa que se vê na condição de público. A menos que, pela própria configuração ética que lhe é concernente enquanto exercício, se chegue a tal. A bem da verdade, sua tentativa de ordenação é por vezes desconexa no sentido de compor um todo significativo, pois ao buscar uma verdade ocultando tudo o mais no qual esta emergiu, também ele desorganiza ao pretender ordenar.

Por outro lado, é na racionalidade ante o entendimento daquilo a que se enuncia que chegamos às condições de possibilidade a ações comunicativas, e não, propriamente, que sejam os relatos em si comunicacionais. Com isto, fazemos então claramente uma separação conceitual entre estar-em-comunicação e pôr-se-a-informar quanto ao modo como se nos apresenta um evento noticiado.

Como exposto até aqui, uma notícia só é aquilo que a constitui enquanto tal por ter havido, antes, relações no mais essencial do in-comunicar enquanto primado quanto a um estar-para-o-outro. Mas sua forma, i.e., produto que assegura o sustento de si como atividade, inaugura uma instância que é discursiva pela termitência com a qual se apresenta; o que nada tem que ver com aquilo a que aqui entendemos como sendo relação. Mais importante até, é compreender que o que surge desses momentos de comunhão simbólica e constante 
negociação é que pode ser tido por comunicacional. E que por certo não teria se mostrado possível na ausência de uma atividade orientada à busca de um verdadeiro pela ordenação dos eventos que lhe são concernentes ao despertar-para. Teriam os sentidos circulados independentemente de enunciados ou não, o que faz do exercício jornalístico, portanto, um tipo singular de intencionar que potencializa as condições de possibilidade a um pôr-se-emrelação e à con-vivência pacífica sempre nos termos de um telos a mostrar-se como tendência única.

Há, entretanto, algo de equivocado no próprio modo como se costuma debruçar sobre a noção mesma de informar enquanto produto que se-destina-a, porquanto, do ponto de vista dos sujeitos que compõem a categoria pelo próprio campo jornalístico tida por público, não há como inferir a respeito de um consumo. Há duas razões para isso: a) em primeiro lugar, informação não é necessariamente dado em estado perceptivo a ser consumido por um sujeito que dele faz algum tipo de inferência a partir de uma coerência que lhe é prévia pela ordenação. Por ser a informação um tipo de dispositivo que nos move a produzir subjetividades a partir de uma coesão que se nos é singular, não há uma instância donde se observa essa intencionalidade mesma de consumir; b) segundo, porque, partindo da premissa de que o ato de informar é também aquilo que nos dis-põe a uma relação possível donde emergem sentidos a serem circulados, a noção de produto guia à contramão do sentido que se toma por negociação, posto que se mostra menos como condição de possibilidade a um conviver, do que, propriamente, um instrumento que se orienta à consecução de algo que não a relação.

Por fim, para não estendermos este tópico mais do que exige a prudência, há um último aspecto atinente ao ato de informar à guisa de um agir ético que é pertinente à breve discussão que aqui se faz: saber até que ponto a intencionalidade informativa no jornalismo é orientada ao oposto de uma teleologia. Em primeiro lugar, partamos da premissa de que o olhar especializado que serve de possibilidade ao ato mesmo de um informar-sobre é, pelas dinâmicas das articulações no interior do campo, uma escolha que opera pela promoção do que pode ou não ${ }^{105}$ ser interessante à atividade. Nesse sentido, há uma dupla dimensionalidade conceitual quanto à ação de se dirigir orientado a algo - no mais aparente de um aspecto seu metafísico -, pois, de um lado, este se mostra como pretensão à finalidade de ordenação e

${ }^{105}$ Conforme o tipo de pretensão informativa. 
seleção, que são caras ao exercício jornalístico. E de outro, com efeito, é ação que se configura pela urgência de despertar um interesse possível.

A ação de promover um acontecimento é, antes, uma publicização que se faz daquilo que aconteceu, donde o ator - i.e., o especialista do campo -, pela observação do vivido, decide de antemão o que é ou não de seu interesse e ao dos demais cuja atividade se destina. Não discutiremos aqui, por questões de espaço hábil e mesmo por obviedades, quais os tipos de valor orientam a atividade jornalística à promoção de um acontecimento ou outro. $\mathrm{O}$ pertinente é compreender que, pela especificidade comunicacional do ato de informar no jornalismo, o que emerge da observação, do olhar especializado que captura um dado evento no vivido e da estruturação que se faz em torno deste a partir de uma ordenação coerente é resultado que não se apresentaria enquanto tal não fossem as articulações que a todo instante fazemos pelas relações em que construímos e fazemos circular sentidos no-mundo. 


\section{PERORAÇÕES}

\subsection{Noções Críticas Conclusivas}

Cônscios de que não foram esgotadas todas as possibilidades de discussão concernente ao problema que aqui pusemos em relevo, encerramos este trabalho tomado pela consciência de que as problematizações aqui propostas suscitam um longo debate até que surjam nos horizontes teóricos consensos um pouco mais apaziguadores. Esperamos, portanto, a partir das nossas problematizações, dar alguma contribuição, por mais modesta que seja, no sentido de que as nossas hipóteses e as nossas conclusões possam incitar um começo às problematizações que levem adiante as questões aqui propostas. Esperamos assim ter trazido alguns esclarecimentos ao menos em parte das dúvidas que foram caras ao princípio da pesquisa e que se veem agora um tanto mais aclaradas.

Até este ponto, tratamos de nos debruçar sobre a noção de informação a partir de um princípio operativo ao construir de relações que se apresentam de modo negociativo e orientadas à convivência por um bem comunalizado que é sempre telos no mais essencial de seu mostrar-se enquanto tal. Mas cabe questionar, por outro lado, em que medida quaisquer tipos de informação se mostram à emergência desta orientação. No bojo da atividade à qual se atém o campo jornalístico, seria então toda intencionalidade como modo de pretenderinformar um asseguramento das situações relacionais?

Em primeiro lugar, centremos a análise em dois limites atinentes ao que aqui se propõe: o da percepção e o da circularidade. É comum ao exercício jornalístico, que o tipo de intencionalidade voltada ao informar a respeito de um evento possível se atenha tão somente àquilo que, à lógica operativa do saber-fazer do campo, seja um tanto mais pertinente que outros de natureza por vezes semelhante. Há pouco, tratamos da dupla dimensionalidade do modo como o interesse se articula nesse espaço, sem muito problematizar até que ponto, da intencionalidade informativa que lhe é própria, as informações do jornalismo tidas na condição de um discurso podem operar à contramão de uma potencialidade negociativa. Consideremos o limite da percepção, no sentido de que, da miríade de eventos narrados a partir da estrutura do campo jornalístico, tão somente um ou outro receberá atenção maior pelos sujeitos componentes do público. Evidentemente, o dispositivo primeiro da atividade é 
menos um centrar de atenções, do que, propriamente, de um despertar à compreensão. Mas o modo como o entendimento se articula entre os sujeitos decorre de uma percepção inicial daquilo que acontece a partir de um modo singular que também o captura a querer compreender. Este modo se dá também pela atenção a que se despende a um acontecimento no mostrar-se do noticiar jornalístico.

Considerando então a premissa de que o entendimento está em consonância com uma espécie de camada a qual atribuímos pela atenção despendida, a circularidade de sentidos que se principia pelos aspectos mais perceptíveis e racionalizáveis desse mesmo acontecimento é a condição para os tipos de significação posteriores ao ato de informar. Temos, de um lado, a ideia de que é pela atenção atribuída a um evento que nos vemos na condição possível de uma formulação de sentidos outros que nos direcionarão a um tipo singular de relação emergida desta dinâmica. Por outro, a de que há um limite operativo da própria narratividade do acontecer, enquanto dispositivo mesmo, a ponto de dar conta de nos capturar a querer despender atenção.

Não há como sabermos em que medida esse querer se articula no sentido de nos dispor a um pairar de atenção, porquanto há aspectos operativos na própria subjetividade que nos fogem a uma racionalização e que também não compõem o escopo da discussão que se faz neste trabalho. Mas é possível observarmos a partir do que, especificamente, o narrar jornalístico como intencionalidade informativa se apresenta enquanto limite compreensível, no sentido de ele próprio ser incipiente a ponto de despertar a uma racionalização que dele então se faz.

À lógica desse operar a partir de um limite que lhe é próprio, consideremos também a premissa de que fixação ou disperção de atenção frente a um acontecimento que se nos apresenta enquanto intencionalidade informativa são também aquilo que emerge das possibilidades de nossa memória. Nesse sentido, o modo como uma notícia nos chega em forma de pretensão comunicativa depende, a ponto de operar enquanto continuidade semântica, do que é excepcionalmente lembrado ou não pelos sujeitos que de um modo ou outro estabelecem tipos singulares de interação com um acontecimento ao qual não presenciaram. Não se trata então de inferir a respeito de algum efeito intrínseco à configuração do ato mesmo de informar, mas de compreender que ele próprio, enquanto ação no mundo, se vê em condições de nos dis-por a um entendimento que, em maior ou menor grau, se vê em consonância com um memorar-se-de. 
É também resultado imediato do exercício jornalístico uma ordenação que se dá pela desordem que lhe é consequência e que se soma à evidenciação de um verdadeiro pelo desocultar do como se chegou a ele. Pois a configuração de sua própria atividade enquanto campo institucionalizado a partir de uma pretensão intencional-informativa é articulada a ponto de se pretender aquilo a que não se obtém como consequência. Trata-se de uma qualidade contraditória na própria intencionalidade informativa: apresentar-se como neguentrópica - i.e., como atividade orientada pela ordenação que elimina a incoerência das coisas mesmas -, mas que, por outro lado, é também entrópica no sentido de desorganizar pelo excesso daquilo a que se informa.

Nesse sentido, a pretensão ordenativa na qual se atém o exercício jornalístico pode, dadas as circunstâncias, ser tão somente uma idealização que se faz em torno daquilo que configura a ação de informar, uma vez que o excesso pretensamente organizativo também conduz a uma desordem que lhe é própria. Mas excesso informacional, por outro lado, não é princípio operativo da atividade jornalística, o que nos conduz a questionar se acaso não é este o aspecto que dificulta as relações possíveis diante do que é informado. Mais até: se exceder a intencionalidade informativa não é pretensão que se soma ao escopo do jornalismo, por que então observar um fenômeno tendo por premissa que há nele uma operação contrária ao formar de relações, se a princípio partimos já da ideia de que o ato mesmo de informar é potencializador de negociações e convivências?

Em primeiro lugar, é preciso compreender a natureza contraditória da própria intencionalidade de informar-sobre, sem desconsiderar o tipo de pretensão que lhe é inerente. A ideia de administração da ordem é cara ao princípio operativo originário do jornalismo: dar continuidade ao que se discutia nos espaços públicos do vivido cotidiano a partir de um todo complexo que se apresentasse coerente a ponto de despertar os sujeitos a um quererrelacionar. Nesse sentido, foi a pretensão dessa continuidade semântica, enquanto desafio à circulação dos sentidos que lhe são concernentes, que serviu como condição de possibilidade à própria articulação da informação como ordenadora de acontecimentos não presenciados. Pelo inesperado, i.e., pela não predictibilidade dos acontecimentos potencialmente noticiáveis do narrar jornalístico, que a pretensão ordenativa se apresenta a ponto de configurar tudo o mais atinente à estruturação que lhe é própria.

Se a raridade - por assim dizer - do conteúdo ao qual se noticia pela ordenação orientada ao ato de informar é o que legitima e dá sentido à própria pretensão de ordenar, não 
é então o evento em si, mas o modo como um de seus elementos se nos é apresentado na intencionalidade do informar. Noutros termos, o que se informa é, antes, o aspecto mais emergencial daquilo ao qual, a partir da não-presencialidade quando do acontecimento em si, se transforma em ação de fato. A tentativa despendida pela impressão mesma de que há um verdadeiro nesse acontecimento não-visto nada tem que ver com uma espécie de pretensão desordenativa na própria intencionalidade de um informar. Porquanto o que se apresenta como excesso é menos princípio operativo inerente ao exercício jornalístico, do que, propriamente, urgência de operar a partir de uma constante ação de informar para assegurar aquilo que se toma por audiência. Ainda assim, esse tipo de operação não lhe é essencial ao sustento de si na condição de atividade, a menos que se considere tão somente o pressuposto de que ela mesma, enquanto tal, deva se orientar pelos ditames da lógica configurativa de um mercado promissor a ponto de moldar as possibilidades de apresentação e articulação da ação noticiosa como produto consumível.

De todo modo, se observarmos a origem da própria urgência de um estado mesmo de coisas em que a informação se visse necessária e constantemente circulada, compreenderemos que o asseguramento de um ordenar-para foi apenas um dos aspectos que articulou as condições de possibilidade mesmo até da estruturação que se fez depois do jornalismo enquanto espaço institucionalizado.

Para que isso fique claro, consideremos a constituição do Estado nos termos modernos, no sentido de que a configuração na qual se articulavam todas as formas de organização hierárquica da monarquia centralizada era menos questão de ordenação a partir de uma intencionalidade informativa, do que de uma urgência política e financeira que movia os interesses a ponto de convergir ações sociais a um único ponto que servia de instância administrativa.

A convergência das operações ao ponto donde se articulava toda administração na ambiência social moderna foi o que abriu caminho à urgência de um querer manter-seinformado-a-respeito-de, pois a sapiência concernente às disposições da corte orientavam o comportamento social. Ver-se informado era, pois, a condição a que chegavam os sujeitos no sentido de se sentirem como partícipes daquilo que emergia de um vivido comunalizado. Noutros termos, informação era a dis-posição, a captura na qual os sujeitos se moviam a um querer-relacionar a partir do que se informava, negociando sentidos a ponto de manter uma con-vivência possível. 
A ciência do que se passa em derredor não é tão somente um falsear de uma ubiquidade pretendida, mas antes, o que emerge do desafio que a própria urgência de se ver cônscio-a-respeito-de impôs ao viver social. Isso, aclimatado à lógica operativa do jornalismo, é o mesmo que inferir que a notícia apresentada como intencionalidade de um pretender-se-informativo é menos a pretensão de uma impressão mesma de que o conjunto dos acontecimentos deve operar em consonância com uma sensação singular de oniciência do que, propriamente, mover os sujeitos ao querer-ver-se-informado, que conduz ao relacionar.

Evidentemente, tratamos aqui de uma essência que é própria à intencionalidade mesma de informar a partir da orientação configurativa de uma notícia; sobretudo no que há nisso de especificamente comunicacional. Por esta razão, entendemos que, excluídas as intenções de um falsear na ubiquidade dos eventos e a arbitrariedade na qual estes nos são apresentados pela articulação discursiva do jornalismo, ainda assim, teríamos a pretensão de relação como uma essencialidade à construção, negociação e circulação de sentidos comuns a uma convivência.

Há, no entanto, que se considerar a possibilidade de que, por um motivo ou outro, as intenções ocultas na atividade jornalística nada têm que ver com a pretensão de dis-por os sujeitos às negociações características de um estar-em-relação. Dito noutros termos, por vezes o que se intenta pela própria continuidade do exercício nada é senão que um estar-come-para segundo a lógica operativa de um tipo de configuração que o excede enquanto tal, qual seja, o mercado que lhe dita as regras. No entanto, a paridade com os intentos dessa estrutura outra também não se apresentam como atributos essenciais tanto ao saber-fazer do jornalismo quanto ao modo singular como este se configura. Por certo, a adequação de seu exercício aos ditames de uma estrutura que lhe é exterior foi também resultado que emergiu de necessidades que capturaram seus profissionais a tipos outros de articulações na própria atividade, muito embora não haja nisto uma especificidade em si comunicacional, a menos que se considere tão somente as relações dos sujeitos que emergem dessas negociações. $\mathrm{O}$ resultado, por outro lado, continua a ser instrumental a ponto de intentar tão somente as condições necessárias ao sustento de si.

Se tratamos, portanto, de uma essencialidade no exercício jornalístico a partir de uma intencionalidade informativa para além da pretensão de ordenar um caos dado a priori no mundo, a dimensão normativa com a qual nos apoiamos até então se apresenta mais que meramente um ideal configurativo do próprio exercício no sentido de ser condição de 
possibilidade a uma relação comunicativa ${ }^{106}$, mas também um aspecto seu singular que lhe é de essência. Noutros termos, ela própria, enquanto agir intencional que nos move, encerra em si o elemento que extrapola a função ordenativa que lhe serve de noção recorrente, o que, com efeito, é a princípio comunicacional. Claro que, em termos gerais, a ação de ordenar sentidos e eventos para engendrar um todo coerente não é necessariamente uma relação, mas se lhe apresenta como condição de possibilidade, até o ponto de mover os sujeitos ao querer relacionar próprio de um ato comunicativo. Do contrário, teríamos como essência sua tão somente o étimo potencialmente patológico do "ismo" que lhe é concernente.

No início deste trabalho ${ }^{107}$, fizemos menção acerca de um limiar como lugar de passagem, i.e., um estado de coisas que nos permite enxergar o que agora, neste ponto, podemos considerar como sendo um princípio não-antinômico entre comunicação e jornalismo a partir da noção de um pretender-se-informativo enquanto intencionalidade mesma. As proposições que pontuaram o início da problematização que aqui se fez ${ }^{108}$ cedem vez agora a um reconhecimento das fronteiras configurativas do próprio operar jornalístico a partir de um fazer comunicativo, no sentido de que há na ação orientada ao informar uma condição de possibilidade à emergência de relações que se nos são possíveis pelo pôr-se- $a$ comungar dos sentidos que fazemos circular pela con-vivência.

O limiar é, portanto, este lugar de passagem que não é tão somente conceitual, porquanto há também nele uma travessia particular, no sentido de nos dis-pormos, a partir do que nos vem-de-encontro como informação, a tipos singulares de relação com os que reconhecemos enquanto semelhantes. Se informar, na atividade jornalística, fosse tão somente uma ordenação arbitrária que emerge da intencionalidade mesma de uma organização coerente imposta, o resultado disso não seria outro senão uma pretensa transferência de saberes. E nada é, pois, menos evidente.

O que emerge do estar-em-relação por esse tipo de agir não é o transferir de saber próprio de um sujeito a outro que a princípio não o tem. Se acaso assim fosse, a atividade jornalística seria menos um informar para conviver comunicativamente do que um impor discursivo daquilo que lhe surge vez ou outra como pretensão. Se não tratamos aqui de uma

\footnotetext{
${ }^{106}$ Muito embora isso não exclua o idealismo quanto à dimensionalidade metafísica do estar-em-comunicação até aqui observada, no sentido de mostrar-se como orientação maior às ações no-mundo.

${ }^{107}$ Cf. p. 25, § 2 e segs.

${ }^{108}$ Quais sejam, as de que comunicação nada tem que ver com o ato mesmo de informar e que, por sua vez, não há algo na atividade jornalística a ponto de ser considerado como especificamente comunicacional.
} 
transferência operada à lógica configurativa do exercício é porque, de modo geral, o entendemos na condição de um encontrar-se. Muito embora não um que se apresente meramente enquanto percepção sensível, mas como tudo o mais que emerge da condição de possibilidade dessa espécie de limiar donde passam os enunciados, os discursos, os usos e desusos que deste se faz e, sobretudo, a circulação semântica que operamos.

Fica assim a questão que se coloca a respeito do pôr-se-a-relacionar que o campo do jornalismo mantém com os que se situam no vivido, donde se extrai os sentidos singulares que servirão como condição de possibilidade ao encontrar-se. Considerando que "importar-se com o outro é estar presente na forma de uma ausência" ${ }^{109}$, somos inteirados de que a ausência primeira na ambiência configurativa que lhe é própria enquanto campo não é tão somente o revelar de um imprevisível pelo ocultar de tudo o mais que se mostrou como condição para tal, mas também, a não presencialidade de uma instância que se faz dialógica e que cede vez a um falsear de relação possível. A intencionalidade do pretender-se-informativo é uma potencialização de encontros perceptivos e empáticos a uma relação orientada pela convivência, muito embora ela própria, enquanto tal e isolada das demais instâncias a partir das quais se desenvolve a atividade jornalística, nada é senão que uma mera pretensão que se reduz à transmissão ou transferência de saberes.

Por isso, então, o informar que se apresenta enquanto narrar-pelo-noticiar, é o que conduz e permeia as relações comunicativas possíveis entre os sujeitos, ao menos nos tipos de circunstâncias em que os acontecimentos são configurados a partir dessa intencionalidade. É como se, a bem da verdade, fosse ele o liço que mantém os fios da urdidura de um tear em constante articulação e rearranjos nesta complexa dinâmica de tecer os sentidos da realidade. $\mathrm{Na}$ tessitura disso a que tomamos aqui por limiar, a informação, numa dimensionalidade normativa que também lhe é de essência, pode operar no jornalismo até o ponto de fazer com que os sujeitos vivenciem o diálogo característico de uma relação. Eis a razão de uma urgência de negociações na condição de encontrar-se das vontades.

Cabe à atividade jornalística, portanto, potencializar a relação a partir de tudo o mais que se mostre às possibilidades de uma intencionalidade informativa, e não, apenas, de abandonar o que se apresenta dialógico para impressionar por um falsear dele próprio enquanto tal e que se orienta pela expressão mesma de um precisar-informar. Por fim,

${ }^{109}$ Cf. EAGLETON, Terry. Depois da teoria: um olhar sobre os estudos culturais e o pós-modernismo. - Rio de Janeiro: Civilização Brasileira, 2005, p. 181. 
deixamos aqui uma contribuição que assoma-se a outras tantas no sentido de se apresentar como passo significativo (ainda que pequeno) à compreensão de uma essência ao fenômeno comunicacional e o modo como sua configuração se apresenta no campo jornalístico. O que propusemos foi tentar compreender se o que consideramos como sendo intencionalidade enquanto pretender-se-informativo pode, dadas as circunstâncias, ser também um tipo de orientação comunicativa que se fundamenta pela solidariedade característica de um estar-emrelação na ambiência do jornalismo, e, por certo, nas instâncias que o extrapolam.

É bem provável que, ao fim, algumas das inquietações primeiras (e outras não previstas) se mostrem mesmo agora pertinentes de discussão, posto que não foram todas as dobras analíticas contempladas no escopo de tematizações deste trabalho. A compreensão de uma essência do fenômeno comunicacional nos é ainda envolta por certo manto de mistério, em que a busca de uma essencialidade e razão absoluta que lhe sejam imanentes se apresenta não mais incognitável e menos inquietante àqueles que se propõem sobre ela deitar o peso de uma análise consistente. Seja como for, o passo aqui dado conduziu à noção de que informar, portanto, se apresenta como condição possível a um comunicar se, de sua vez, carregar na própria configuração a pretensão de um relacionar-com-e-para-o-outro. Ou se, ele próprio, enquanto ato, guiar ao querer que nos move à relação no limiar dos sentidos que emergem de um pôr-se-a-comungar que é sempre telos à comunicação no mais essencial de seu semostrante. 


\section{REFERÊNCIAS}

AGAMBEN, Giorgio. O que é o contemporâneo? E outros ensaios. Chapecó, SC: Argos, 2009.

BERLO, David. O processo da comunicação: introdução à teoria e à prática. SP, Martins Fontes, 1999.

BOURDIEU, Pierre. O poder simbólico. - 13ª ed. - Rio de Janeiro: Bertrand Brasil, 2010.

BRAINARD, Marcus. Belief and Its Neutralization: Husserl's System of Phenomenology in Ideas I. New York: State University of New York Press, 2002.

CRESPO, Mariano. El amor como motivo ético en la fenomenología de Edmund Husserl. Anuario Filosófico v. 45 n. 1, 2012, p. 15-32.

DOSSE, François. Renascimento do acontecimento. São Paulo: UNESP, 2013.

DREYFUS, Hubert. Heidegger's Critique of Husserl's (and Searle's) Account of Intentionality. In: Social Research, Vol. 60, No. 1. Spring, 1993.

DUARTE, Jorge; BARROS, Antonio (Orgs.). Métodos e técnicas de pesquisa em comunicação. $-2^{\text {a }}$. ed. -6 . Reimpr. - São Paulo: Atlas, 2012.

EAGLETON, Terry. Depois da teoria: um olhar sobre os estudos culturais e o pósmodernismo. - Rio de Janeiro: Civilização Brasileira, 2005.

FERRY, Jean-Marc. Filosofia da comunicação: da antinomia da verdade à fundação última da razão; justiça política e democracia procedimental. São Paulo: Paulus, 2007.

HABERMAS, Jürgen. Mudança estrutural da esfera pública: investigações quanto a uma categoria da sociedade burguesa. Rio de Janeiro: Tempo Brasileiro, 1984.

, Jürgen. Conhecimento e interesse. - trad. José N. Heck - Rio de Janeiro:

Guanabara, 1987.

, Jürgen. Teoria do agir comunicativo, 1: racionalidade da ação e racionalização social. São Paulo: WMF Martins Fontes, 2012.

Jürgen. Teoria do agir comunicativo, 2: sobre a crítica da razão funcionalista. São Paulo: WMF Martins Fontes, 2012.

HEGEL, Georg Wilhel. Fenomenologia do espírito. - 7ª ed. rev. - Petrópolies, RJ: Vozes: Bragança Paulista: USF, 2002.

HEIDEGGER, Martin. A questão da técnica. In: Revista Scientiae Studia. - V.5, N.3 - São Paulo: USP, 2007, p. 375-398. 
, Martin. Introdução à filosofia. - 2 $2^{\mathrm{a}}$. ed. - São Paulo. Martins Fontes, 2009.

, Martin. Ontologia: hermenêutica da faticidade. Rio de Janeiro: Vozes, 2012.

, Martin. O acontecimento apropriativo. - trad. Marco A. Casanova -, Rio de

janeiro: Forense; Alemanha, 2013.

, Martin. Ser e tempo. - Trad. Fausto Catilho - Campinas, SP: Editora da Unicamp;

Petrópolis, RJ: Vozes 2012.

HOPKINS, Burt. Intentionality in Husserl and Heidegger: the problem of the original method and phenomenon of phenomenology. New York: Springer, 1993.

HUSSERL, Edmund. Experience and judgment. Australia: Law Book Co., 1973.

, Edmund. A crise das ciências europeias e a fenomenologia transcendental: uma introdução à filosofia fenomenológica. - 1. ed. - Rio de Janeiro: Forense Universitária, 2012.

, Edmund. A ideia de fenomenologia. Lisboa: Edições 70, 2008.

1977.

, Edmund. Formal and Transcendental Logic. New York: Springer Netherlands,

Edmund. Ideas pertaining to a pure phenomenology and to a phenomenological philosophy: Studies in Phenomenology of the Constitution. Husserliana: Edmund Husserl Collected Works, Vol. 2. U.S.A: Springer (Kluwer Academic Publishers), 1983.

Madras, 2001.

Edmund. Meditações cartesianas: introdução à fenomenologia. São Paulo, SP:

KOVACH, Bill; ROSENSTIEL, Tom. Os elementos do jornalismo: o que os jornalistas devem saber e o público exigir. - 2. ed. - São Paulo: Geração Editorial, 2004.

LÉVINAS, Emmanuel. Humanismo do outro homem. Petropolis, RJ: Vozes, 1993.

Emmanuel. Entre nós: ensaios sobre a alteridade. Petrópolis, RJ: Vozes, 1997.

LIHON, Danilo Sanchez. Teoría y practica de la informacion. Lima, Peru: INIDE, 1985.

LOUISE THOMAS, Elizabeth. Emmanuel Lévinas: ethics, justice and the human beyond being. New York: Taylor \& Francis Books, 2004.

LUHMANN, Niklas. A realidade dos meios de comunicação. - trad. Ciro Marcondes Filho

- São Paulo: Paulus, 2005.

MARCONDES FILHO, Ciro. Comunicação e jornalismo: a saga dos cães perdidos - 2. ed.

- São Paulo: Hacker Editores, 2002. 
MONTALBÁN, Vázquez. Inquérito à informação: o fundo do problema da informação. Lisboa, Portugal: Iniciativas Editoriais Lisboa, 1971.

MOUILLAUD, Maurice; PORTO, S. Dayrell (Org.). O jornal: da forma ao sentido. - 2. ed. Brasília: Editora Universidade de Brasília, 2002.

RODRIGUES, Adriano Duarte. Estratégias da comunicação: questão comunicacional e formas de sociabilidade. Editorial Presença - 2a ${ }^{\mathrm{a}}$ ed., Lisboa -, 1997.

ROUSSEAU, Jean Jacques. Do contrato social: Ensaio sobre a origem das línguas; Discurso sobre a origem e os fundamentos da desigualdade entre os homens; Discurso sobre as ciências e as artes - trad. Lourdes Santos Machado - 2a . ed., Sao Paulo: Abril Cultural, 1978.

SEARLE, John. Intencionalidade. $-2^{\mathrm{a}}$. ed. - São Paulo: Martins Fontes, 2002. , John. Consciência e linguagem. São Paulo: WMF Martins Fontes, 2010.

SFEZ, Lucien. Crítica da comunicação. Edições Loyola: São Paulo - 2a . ed. - 1994.

SOKOLOWSKI, Robert. Introduction to phenomenology. USA: Cambridge University Press, 2000.

VASSALO DE LOPES, Maria Immacolata (Org.). Epistemologia da Comunicação. - São Paulo: Edições Loyola, 2003.

VICKERY, Brian; Alina. Information science in theory and practice. UK: Butterworth \& Co, 1987.

WILLIAMS, Raymond. Cultura e sociedade: 1780 - 1950 São Paulo: Companhia Editora Nacional, 1969.

WOLTON, Dominique. Pensar a comunicação. Brasília: Editora Universidade de Brasília, 2004.

, Dominique. Informar não é comunicar. Porto Alegre: Sulina, 2011.

\section{REFERÊNCIAS COMPLEMENTARES}

BRAGA, José Luiz. A sociedade enfrenta sua mídia: dispositivos sociais de crítica midiática. São Paulo: Paulus, 2006.

DELEUZE; Gilles. Conversações - Rio de Janeiro: Ed. 34, 1992. 
, Gilles. Lógica do sentido. - 5 . ed.; 2a . reimp. - São Paulo: Perspectiva, 2011.

EAGLETON, Terry. A ideia de cultura. - São Paulo: UNESP, 2005.

FAUSTO NETO, Antônio. A circulação além das bordas. In: Mediatización, sociedad y Sentido: Diálogos entre brasil y argentina. Coloquio del proyecto "mediatización, sociedad y sentido: aproximaciones comparativas de Modelos brasileños y argentinos". Programa de cooperación científico-tecnológico. Mincyt-capes, 2009-2010, p. 02-17.

GUMBRECHT, Hans Ulrich. Cascatas de modernidade. In: Modernização dos sentidos. São Paulo: Ed. 34, 1998, p. 9-32.

INWOOD, Brad (Org.). Os estóicos. - Trad. Raul Fiker -. São Paulo: Odysseus Editora, 2006.

KANT, Immanuel. Crítica da razão pura. - 2a . ed. - Petrópolis, RJ: Vozes; Bragança Paulista, SP: Editora Universitária São Francisco, 2013.

LUHMANN, Niklas. Social systems. Stanford University Press. United States of America, 1995.

LYOTARD, Jean-François. A fenomenologia. Lisboa: Edições 70, 2008.

MALDONADO, Alberto E. [et al.]. Metodologias de pesquisa em comunicação: olhares, trilhas e processos. $2^{\mathrm{a}}$. ed. Porto Alegre: Sulina, 2011.

MARTIN-BARBERO, Jesus. Dos meios às mediações: comunicação, cultura e hegemonia. - 6 ${ }^{\text {a }}$ ed. - Rio de Janeiro: Editora UFRJ, 2009.

MARX, Karl; ENGELS, Friedrich. A ideologia alemã - crítica da mais recente filosofia alemã em seus representantes Feuerbach, B. Bauer e Stirner, e do socialismo alemão e seus diferentes profetas (1845-1846). - São Paulo: Boitempo, 2007.

PIGNATARI, Décio. Informação, linguagem, comunicação. São Paulo: Ateliê Editorial, 2002.

ROLNIK, Suely. Toxicômanos de identidade: subjetividade em tempo de globalização. In: LINS, Daniel S. (Org.) Cultura e subjetividade: saberes nômades - Campinas, SP: Papirus, 1997, p. 19-24.

SIGNATES, Luiz. A sombra e o avesso da luz: Habermas e a comunicação social. Goiânia: Kelps, 2009.

SILVEIRA, Ada C. Machado [et al.], (Orgs.) Estratégias midiáticas. - Santa Maria: FACOS - UFSM, 2012. 